THE EFFECT OF VARIOUS FACTORS

\title{
ON VEHICLE SPEEDS
}

(A REVIEW OF THE LITERATURE)

MARCH 1963 
Digitized by the Internet Archive in 2011 with funding from

LYRASIS members and Sloan Foundation; Indiana Department of Transportation 


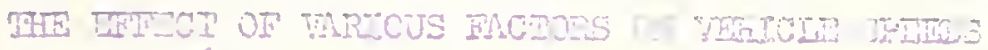

A Revicit or the interusure?

TO: K。 B. Woòs, Director

Toint Bighiry Researin Eaojest

$\therefore$ - 2 ci工 $20, \quad 2863$

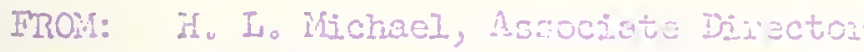

Pine: 8mi, o.25

Joint Highrey Research Frojeat

Pioject: $3036-i 72$

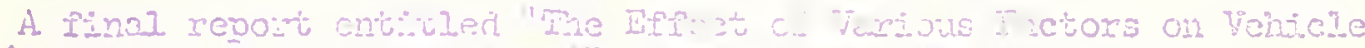

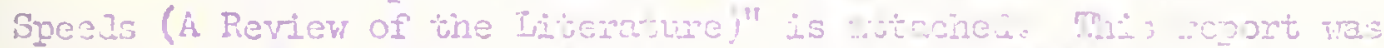

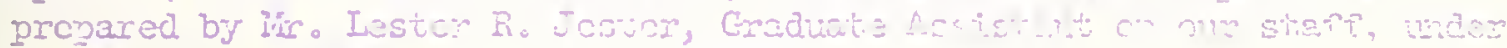

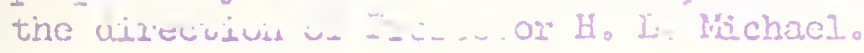

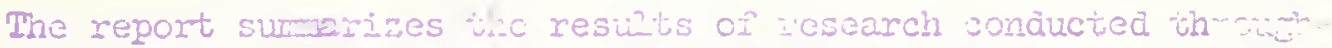

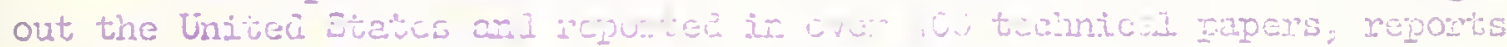

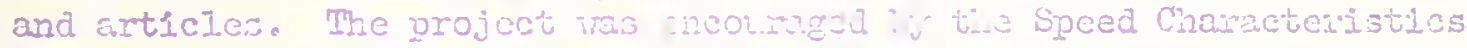
Cormittee of the Highray Resea in Ecand and inl be sumitted to that

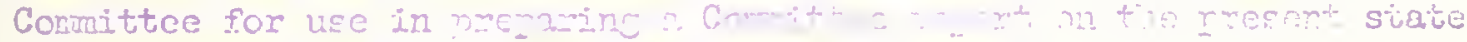
of the lonorledge of the characuristics of steed.

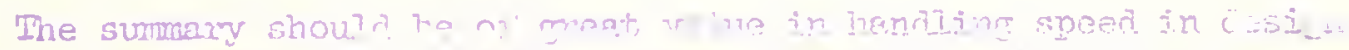

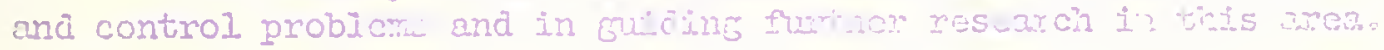

The report is presont 3 to the Evara for the resida

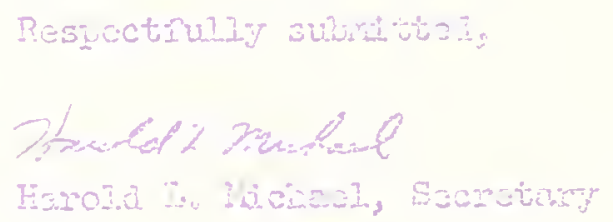

I.T:1: icue

Attachment

\section{Coples:}

T. I. Asbbevicier

J.R. Ccoper

I. T. Dolch

H. I. Goetz

5. F. Havey

F. S. IIIII.

G. A. Iseonaxds
I. E. MEIsughin

I. D。 MIIIJ

R.F. Minls

I: B. Berot

Jo r. suthe

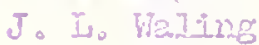

E. I. Ioder 


\section{Final Report}

THE GFFECT OF VARIOUS FACTORS ON VEFICLE SPEFDS

$$
\text { (A Review of the Literature) }
$$

$$
\text { by }
$$

Iester R. Jester

Graduate Assistant

Joint Highway Research Project

File No: 8-4-25

Project No: C-36-17Y

Purdue University

Lafayette, Indiana

March 20, 1963 


\section{ACKNOWLEDGAENTS}

The author wishes to express his sincerest appreclation to Professor Harold L. Mlchsel, Assoclate Director, Jolnt Highway Research Project, for his assistance in all phases of the study and in the preparation and revlew of the manuscript; to Professors Robert D. Mlles and J. C. Oppenlander Jo1nt Highway Research Project, for their revlew of the manuscript; to the Speed Characteristics Comblttee of the Highway Research Board for making their flles avallable for use; to the mang Individuals and organ1zations who cooperated by supplying copies of material relative to speed characteristics; and to the staff of the Joint Highway Research Project for their valuable assistance throughout the study. 
TABLE OF CONTENTS

LIST OF FIGURES . . . . . . . . . . . . . . . . v v

ABSTRACT ..................................... vi

INTRODUCTION ............................. 1

PURPOSE . . . . . . . . . . . . . . . . . . . . . 3

PROCEDURE . . . . . . . . . . . . . . . . . . . . 4

SPEED TRENDS ........................... 5

ROAD GEOMETRY . . . . . . . . . . . . . . . . . . . 9

Horizontal Curvature ................. . 11

Vertical Allnement ................. 15

Passing Sight D1stance ............... . . . 18

Cross-Section Elements ..................... 18

Number of Lanes.................... . . . . . 18

Lane Width . . . . . . . . . . . . . . . . 19

Lane Position . . . . . . . . . . . . . . . . 21

Road Surface Type .. . . . . . . . . . . . . . . 21

Medians . . . . . . . . . . . . . . . . . . 22

Curbs ... . . . . . . . . . . . . . . . 23

Shoulders .... . . . . . . . . . . . . . . . 23

Lateral Clearance . . . . . . . . . . . . . . 23

Friction Points . . . . . . . . . . . . . . . 25

Speed Change Lanes . . . . . . . . . . . . . . . 27

TRAFFIC STREAM CHARACTERISTICS - . . . . . . . . . 28

Speed, Volume, and Density . . . . . . . . . . . . 28

Longltudinal Distribution . . . . . . . . . . . . 33

Passing . . . . . . . . . . . . . . . . . . . 34

Traffic in the Opposing Direction.............. 35

Driver Residence ................... . . . 36

VARIATION WITH TIME . . . . . . . . . . . . . 38

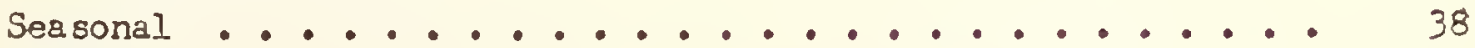

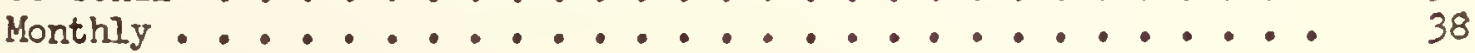


Daily ........................... 38

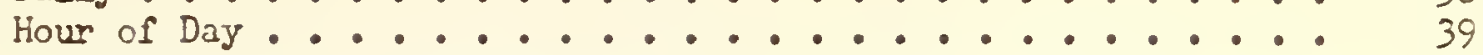

Day vs. Night ....................... 40

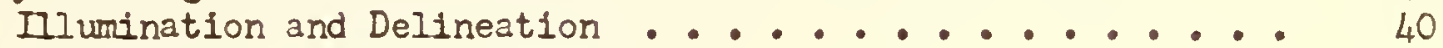

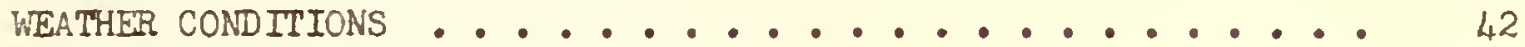

SPEED CONTROL MEASURES ............................. 44

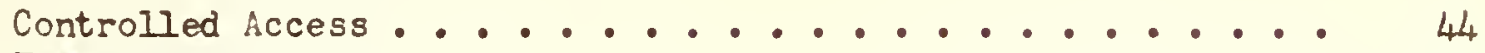

Enforcement ..................... 45

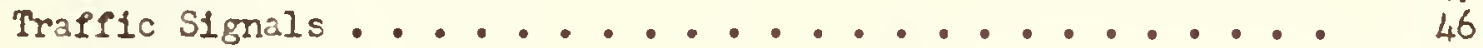

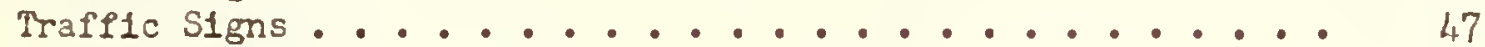

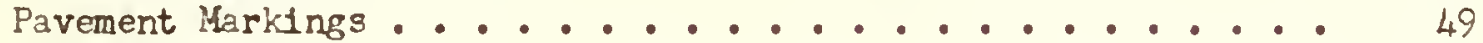

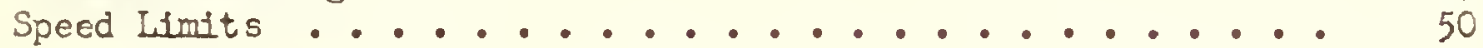

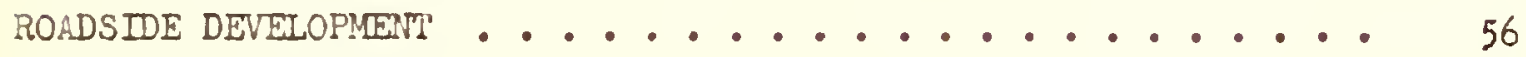

OTHER CHARACTERISTICS .................... 58

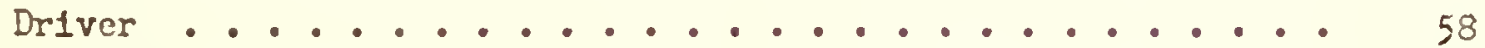

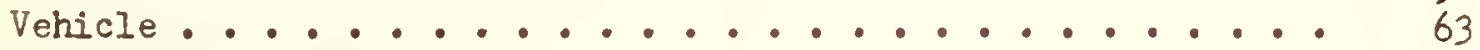

Speed idvertisements ....................... 66

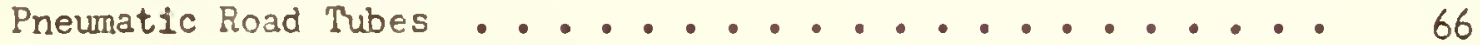

SPEED AND ACCIDENTS ............................. 67

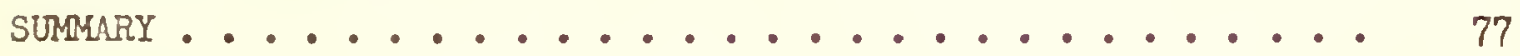

BIBLIOGRAPHY ...................... 90

General Relerences .................... 121 


\section{LIST OF FIGURES}

Figure

1. Speed Trends on MaIn Rural Highways by

Vehicle Type . . . . . . . . . . . . . . .

2. Minimum Distance from Collision Point to Decision

Polnt for the Minimum Total Delay for Various Midblock

Speeds at a Non-Controlled Intersection ......... 26

3. General Speed-Volume Dlagram ............. 30 
ABSTRACT

Jester, Lester R., MSCE, Purdue University, January 1963. The Effect of Varlous Factors on Vehicle Speeds (A Review of the Lfterature). Major Prolessor: Harold L. Michael.

The subject of vehicular speed is highly controversial. It has occupled a prominent position in highway and traffic engineering literature, yet it is probably the least understood characteristic of traffic. Some of the factors affecting vehicle speeds are not stable with time; therefore, research has to be performed on a continuous basis in order to understand their current signlficance.

Numerous Individuals and organizations have made many studies, and many articles have been written concerning the characteristics of motor vehicle speed and the effects of conditions and controls on speed. The purpose of this study was to review, evaluate and summarlze this published information relative to motor vehicle speeds and the effect of various factors on speed.

The procedure was to study the avallable literature, evaluate the quality of the reported material based on the qualifications of the author, methods of data collection, methods of analys1s, mathematical procedures, and date of study and to summarlze the results obtained. . 
The relationship of the following factors to speed as reported in over 400 technical papers, reports and articles are brlefly sumarized in the report:

1. Speed Trends

2. Road Geometry

a. Horlzontal Curvature

b. Vertical Alinement

c. Pasoing S1ght Distance

d. Number of Lanes

e. Lane hidh

1. Lane Position

8. Road Surface Type

h. Medians

1. Curbs

j. Shoulders

k. Lateral Clearance

1. Priction Points

I. Speed Change Lanes
4. Variation with TIme

a. Monthly

b. Da1ls

c. Hour of Day

d. Day vs. Might

5. Weather Conditions

6. Speed Control Measures

a. Controlled Access

b. Enforcement

c. Traffic S1gnals

d. Traffic S1gns

- Pavement Markings

f. Speed Limfts

7. Roadside Development

8. Other Characteristics

3. Traffic Stream Characterlstics a. Driver

a. Speed, Volume and Density b. Vehicle

b. Longitudinal D1stribution c. Pneumat1c Road Tubes

c. Passing

9. Accidents

d. Traffic in the Opposing Direction

e. Driver Residence 


\section{INTRODUCTION}

In the fleld of Traffic Engineering there are many factors to be considered. Many of these factors besides belng variable exhiblt changing quant1tative values over time. Research, therefore, has to be done on a continuous basis in order to evaluate them properly. One important factor which has occupled a prominent position in highway and trafflc englneering Iiterature, but which 13 probably the least understood of all traffic characteristics, 1s speed.

The subject of vehicle speed is highly controversial. Generally speaking, people have little consistency in their thoughts relative to vehicle speeds. They want stralght, smooth, wide, level hlghways, and more powerful, stronger, lower, streamlined vehicles, yet they often protest the speeds which naturally result from these improvements.

Several articles have been written and many people have maintained that speed 1s detrimental. Others have contested this statement with the Idea that it 1 s "speed too fast for conditions" rather than speed alone that 18 detrimental. Certainly the recent manned orbltal flights should prove that speed alone is not detrimental; the astronauts traveled at speeds In excess of $17,500 \mathrm{mph}$ with no apparent 111 effects. One can never hope to attain speeds of this magnitude from wheeled vehicles on the highway system; however, It should be apparent from the space example that "conditions" determine which speeds are safe. 
One of the problems facing the traffic engineer today is how to develop and use devices which will assist in controlling and utilizing, safely and efficlently, the speed which vehicle drivers are capable of mastering for the varlety of conditions which confront them. The combined efforts of highway and vehicle design englneers have provided progressively safer highways and vehicles; some contend, however, that the average driver has shown limfted ablilty to cope safely with high speeds on the highway.

McKonagle (206)* said: "Speed is one of the great essent18l benefits which make highway transportation 1nd1spensable in modern America. It must be provided for and protected." In order to "provide for and protect" this essent1al benef1t, every trafflc engineer should be aware of the stste of the knowledge relative to speed.

Nhmerous Individuals and organtzations have made mano studies and many articles have been written about the characteristics of motor vehicle speed and the effects of conditions and controls on speed. Much of this Information is valuable but most of the studies and articles have been Iindted to one or a few aspects of speed. As a result, anjone who desires information of the effect of varlous elements on vehicle speeds has to review much of the literature on the subject or conduct another study. Valuable effort and time as a consoquence often are wasted.

* Numbers in parentheses refer to sources listed in the Blbllography. 


\section{PURPOSE}

The purpose of this study was to revlew, evaluate and sumarize the avallable publlshed Information relative to motor vehicle speeds and the effect of various factors on speed.

The Speed Characterlstics Comalttee of the Highway Research Board strongly supported the conduct of this study and cooperated in supplylng Information avallable in its flles. 
PROCEDURE

The procedure used was to revlew the avallable litersture relative to vehicle speeds and to summarize the results obtained. Some consideration in each review was given to quality of the information, based on known qualificat1ons of the author, methods by which the data were collected, methods of analys1s, mathemat1cal procedures, and date of study. The Information was then grouped and summarized under the major factors .. of road geometry, traffic-stream characterist1cs, time, weather conditions, speed-control measures, roads1de development, and other characteristics.

The Bibllography of this report containg a llsting of the itemg from the literature which were used in preparing this report. Many other items which contained some reference to speed characterlst1cs were also revlewed but were not used in preparing this summary report (and are not listed in the Blbllography) because the Information was of a minor nature, Incidental to the article in the literature, or obviously based on opinion only. A tremendous amount of literature has been produced on speeds, however, and It is undoubtedly true that a number of excellent 1tems were not reviewed, In some cases because of non-avallability, in others because they were not found in the careful search whlch was made. 
SPEED TRENDS

The maximum speed of a vehlcle is primarily a matter of the type of fuel used and the vehicle design, but actual speed driven on a given roadway is dependent to a great extent on the environment and the desires of the road user (191). Speed data for free-moving vehtcles on level, tangent, two-lane rural highways during daylight hours in falr weather clearly show that average driving speeds have increased over the years (14, 15, $16,31,36,39,61,62,135,149,210,255,281,284,287,298,337,344$, $348,388,389,390,402,404,405,406,407,408,417,430,448)$. Iowa reported an average speed of $21 \mathrm{mph}$ as early as 1910 (127). A state-wide speed survey conducted in Rhode Island in 1925 showed an average speed of 25.6 mph with a range from 14 to $61 \mathrm{mph}(73,125,268)$. The average speed in 1933 of free-flowing vehicles in Maryland was $35.5 \mathrm{mph}$ (154), while the average speed for passenger cars in Indlana was $44.5 \mathrm{mph}$ (271). Speed checks made in Michigan in 1934 showed an average vehicle speed on paved highways of $43.3 \mathrm{mph}$ (121).

The average speed, however, was not the same each year for all sections of the UnIted States; average speed was typically higher in the west than in the east, with differences as much as ten mph. Continuous records of speed trends prior to World War II, however, are very scarce. During the depression years of the 1930's some states made fairly intensive speed studies $(121,144,154,293,329,396)$; these studies, however, were not reported on a year-to-year basts and as a result accurate speed trends have not been established for mans states. 
Rhode Island was the first state to begln collecting continuous speedtrend information. There the average speed - mean speed of free-flowing vehicles on major rural arterial highways - increased from 25.6 mph in 1925 to 34 mh in $1934(73,125,268,287)$. All stud1es, however, have not shown increases in average speed for all perlods of time. Intensive studies made by the Bureau of Public Roads at seven locations in New York In 1935 disclosed an average speed of $43.5 \mathrm{mph}$. These same locat1ons were re-studied in 1950 by Now York highway offlcials, and the average speed was found to be $41.7 \mathrm{mph}$. Trafflc volumes were about the same for the two sets of speed data and roadway conditions were slutlar (287). The highways on wilch these speeds were obtained, however, were considered excellent in 1935 but were not good rural arterlals by 1950 standards. The 1950 study did show, however, a noticeable increase in the concentration of speeds around their central value.

By 1941 several states had started to make more or less continuous speed studles $(284,287)$. Then In 1942 when gasoline and rubber was restricted, followed by a nation-wide speed limit of 35 mph, several other states began maklng large scale speed studies which have been continued $(15,16,31,97,127,142,241,255,268,295)$.

In 1941 the Bureau of Public Roads began collecting this "speed trend" data from several states, and reporting the information in their "H1ghway Stat1st1cs" publlcation (348). These studles showed a sharp reduction In average speed in the early spring of 1942, because of the war-time controls. From a pre-war high of $47 \mathrm{mh}$, the national average speed for passenger cars on main rural highways dropped to a war-time Low of $36 \mathrm{mph}$ in the fall of 1942, bounced back to $39 \mathrm{mph}$ by early 1943 , 
slowly increased to $48 \mathrm{mph}$ in 1948, remained palrly constant until the middle of 1950, then gradually increased to $53,8 \mathrm{mph}$ in 1960 (see P1gure 1) $(287,348)$. Of the different vehicle types, buses have been cons18tently a little faster than passenger cars, and trucks somewhat slower; however, the increasing trend has been similar for all three vehtcle types (F1gure 1) (21, 43, 97, 119, 130, 144, 186, 268, 295, 348, 353, 359, $388,389,390,416,430,448)$

The speed trends as shown in F1gure 1 are average values as reported by many states scattered throughout the Unlted States, and are not Intended to represent ang state in particular as far as average speed values are concerned. However, speed trends as reported by Individual states roughIg parallel those shown in P1gure $1(388,389,405,406,407,408)$. The speed trend since 1960 has been similar to that noted in Figure 1 for the years just prior to 1960.

Vehicular-speed patterns by geographic location have been studied by several authors, and it has been generally concluded that average speeds on main, rural highways in the central and western reglons of the Unt ted States are consistentiy four to seven mph higher than those in the eastern regions $(21,69,183,287,407,408)$. It has been further concluded that not only are there differences between one region and another, but also within a single reglon there may be some varlation from one area to another $(69,250,257,287,407,408)$. On the other hand, a trafflc speed survey in Canada in 1956 found that, under similar roadway conditions, there was little dffference between motor-vehtcle speeds on main rural highways in Ontar10 and in the Untted States (75). 


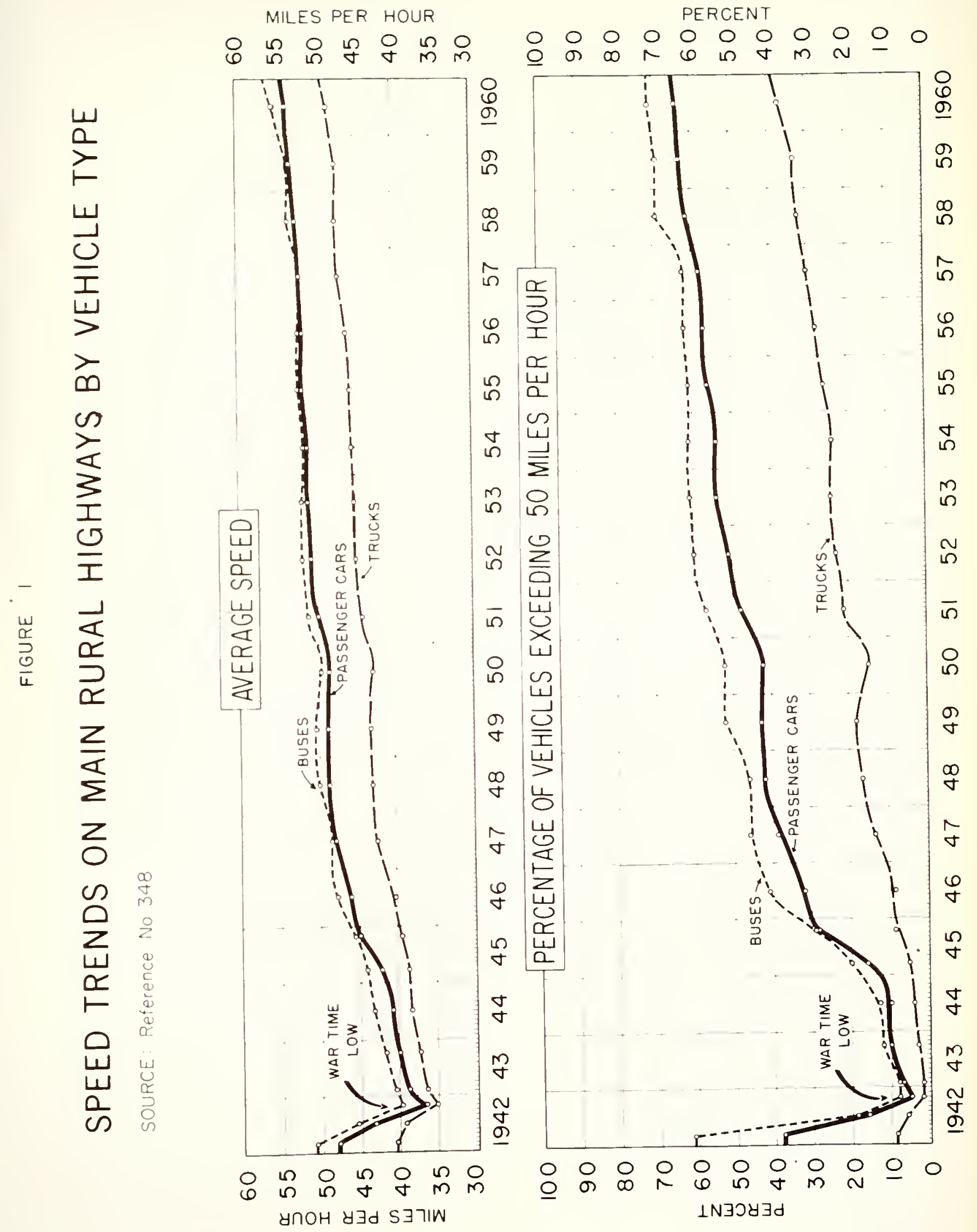


Road Ceometry

Existing highways are conglomerations of varled geometric designs. Some sections are deslgned in accordance with the most modern standards so as to accommodate large volumês of traffic at relatively high speeds, but these are still very much in the minority. A great part of our highway system was designed and constructed twenty, thirty, and even forty jears ago, and obviously was not designed for present day volumes or vehicle speeds.

Vehicle speeds on major arterial streets are limited by traffic control devices, frequent intersections, peak traffic volumes, close proxim1ty to lateral obstructions, and many other physical and psychological factors peculiar to the urban environment and are not affected appreciably by typlcal street geometry. On rural highways and some urban expressways, however, the geometric design elements of the roadway are major influences on the maximum safe speeds at which vehicles can operate (1). As the mafor factor which determines the geometric design standards for highway is its classification, the classification of highway facilities is a variable which influences speed characteristics. In a speed study conducted in Pennsylvania in 1954, it was found that speeds of all vehicles showed a progressive increase from secondary to primary to the Interstate system (151, 338). Field observations made in 1959 in 17 Fastern States indicated that vehicular speeds were higher on toll roads than on free routes for the typical and similar traffic volumes using these facilities $(45,307)$. 
Speeds of all vehicles increased progressively on rural highways in New York, from primary-feeder to intercity to interstate-and-interregional highway systems $(69,178)$. The speed differences by highway type, moreover, remalned quite constant throughout the range of traffic volumes 251, 259).

In making the transition from rural to urban, average vehtcular speeds decrease as the driver advances from sparsely developed areas through moderately developed and into the densely built-up down town area (53, $122,189,212,250,257,302)$. The factors causing this variation in speed are many and varied. In a study of transition sections between rural and urban areas made by N. J. Rowan and C. J. Keese in Texas (302) it was found that: "---for short transition sections the inbound and outbound speed patterns were significantly different. There was noted a general divergence between the speed proflles of the two directions. Th1s characteristic was observed in the other studies where transition sections were longor, but the divergence was much smaller." Average speeds Wthin the transition zone from rural to urban were found to be faster for vehicles entering the urban area than for those vehicles leaving the urban area (65). Th1s is probably explained by the fact that drivers after traveling at high speeds do not slow down appreciably until forced to do so by the urban frictions.

Extending the Influence of highway functional classification on vehicular speeds to urban roadways, the followlog ranges of average speeds on various streets in Detroit and Lansing, Mlchigan were reported by A. D. May, Jr.: freeways - 40 to $60 \mathrm{mph}$; unsignallzed arter1als - 32 to 40 mph; signalized arterlals in intermediate areas - 22 to $32 \mathrm{mph}$; and 
signalized arterials in downtown areas - below $22 \mathrm{mph}$ (192). Speeds observed on one-way streets in Sacramento, Callfornia were consistently higher than those for trefflc movement on two-way streets (88).

\section{Horizontal Curvature}

Insufficlent sight distance for safe operation at desired speeds on vertical and horlzontal curves is the most comon deflciency in geometric design of the older highways in many rural locations. The maximum speed at which a vehicle can traverse a curved path without leaving the roadway is governed by the laws of physics $(2,191,236)$. The factors which effect this "critical speed" include the radius of the curve, the roadway superelevation, the sight distance and the coefficient of side friction. Many studies were made in the $1930^{\prime} \mathrm{s}$ and early $1940^{\prime} \mathrm{s}$ in an attempt to correlate "critical speeds" with these different factors $(20,22,95,212,233$, $246,247,290,397)$.

C. B. McCullough correlated average spot speeds with horizontal curvature, as measured in total degrees of central angles per mile, in his investigation of the economics of highway alinement in 1937-1938. The study was made on rural highways in Oregon, and 1t was found that the average speed decreased with an increase in the total degrees of central angles per mile. The rate of decrease, however, was smaller for larger total degrees than for smaller totals (201).

D. M. Baldwin empirically developed a third-degree polynomial equation for maxdmum safe and comfortable speeds (which he defined as critical speeds) Prom speeds observed on horizontal curves in Illinois in 1934. The equation is $V_{c}^{3}=466 R(e+0.2)$, where $V_{c}=$ critical speed in miles 
per hour, $R=$ radius of curvature in feet, and $e=$ superelevation in feet per foot of roadway width. Thls equation, $\nabla_{c}^{3}=466 R(e+0.2)$, was dereloped for clrcular curves without splralled transition sections and where the pavement ourface was of average smoothness. Higher critical speeds were noted on horlzontal curves with splralled transition sections (289). * Speed data collected on two-lane rural highwago in flve states during 1951-1953 for passenger cars operating on horizontal curves with minimum s1ght d1stance rangling from 200 to 655 feet and with curvatures from three to 29 degrees were analyzed by the Bureau of Public Roads and reported by A. Taragin. A hlghly slgnlflcant linear relationshtp was found to exdst between spot speed and degree of curvature for these data. The linear regression analjsis gave the equation, $S=46.26-0.746 \mathrm{D}$, where $S$ is the speed in miles per hour and D is the degree of currature. The adjusted standard error was found to be $3.15 \mathrm{mph}$ and the adjusted correlation coefficient $0.819 . \quad(377,378)$

In an attempt to obtain the relationship of alght distance and curvature to speed, A. Taragin considered the three in comblnation. The method of least squares was used to analyze the data and the results were represented by average-speed contours plotted on a graph having curvature as the ordinate and minfmum sight distance as the absc1ssa. The standard error for the speeds was found to be $3.09 \mathrm{mph}$. It was concluded that curvature causes nearly three times as great a change in speed as does sight d1stance. $(377,378)$

Another element of horlzontal alinement whtch affects vehtcular speeds $1 \mathrm{~s}$ superelevat1on. Stud1es conducted on the Pennsylvanta Turnplke 
in 1940 indicated that vehicles were operated at higher speeds on highly superelevated curve than they were on llat curves. The average person possesses an inherent sense of balance; therefore, the driver tries to drlve at a speed such that the angle of roll is equal to the angle of superelevation. (369)

A. Taragin did not find this same relationship in his report of 1954 $(377,378)$. He said, "The amount of superelevation on the curves studied had no effect on vehtcle speeds. For this reason the utilized coefficient of slde friction on the same degree of curvature 1s smaller when the superelevation is high than when it is low..." He further concluded that; "Superelevation, as normally used in terms of reet of rlse per foot of pavement width, w1thout regard to the sharpness of the curre, bears no relation to the percentage of vehicles exceeding the 'safe' speed based on curvature, superelevation, and coefficient of side friction. A close correlation exists, however, between unit superelevation and the percentage of vehicles exceeding the computed safe speed based on curvature and superelevation, the 'unit euperelevation' belng the feet of rise per foot of width per degree of curvature. The analysis indicates that few vehtcles exceed a safe speed on horizontal curves designed with a unit superelevation of more than 0.005 foot per foot of width per degree of curvature." The extent to which vehtcular speeds are modified by side friction (the remaining element of borizontal alinement) tends to be governed by the drifers' comfort and stability. In road teats conducted by the Bureau of Public Roads, data from nine hundred such tests from widely separated sections of the country were analyzed. The tests indicated that a sidefriction factor of 0.16 was utilized at speeds of $60 \mathrm{mph}$ and below (22). 
Other tests made on the Pennsylvania Turnpike by highly skilled drivers with stock model automobiles indicated that unstable steering conditions were felt when the side-friction factor exceeded 0.10 at $70 \mathrm{mph}$. It was Indicated that these "conditions" might have been disastrous for less experienced drivers (369).

From these and other studies $(2,191)$ the American Association of State Highway Officlals concluded that; "the maximum values of side friction to be used in the design of non-intersectional horizontal curves should vary directly with the design speed from 0.16 at $30 \mathrm{mph}$ to 0.12 at 70 mph."

Numerous investigations of traffic stream characteristics have concluded that vehicular speeds on horlzontal curves are lower than those on tangent sections, and that the average spot speed more closely approaches the design speed of the curve as the degree of curvature increases $(2,250$, 257, 312, 365). It was also found that the average-spot speed on a curve designed for a slow speed was nearer the design speed than the average spot speed on a curve designed for a higher speed. The average spot speed on curves designed for high speeds approaches the average speed observed on tangent sections $(2,377,378)$.

A Taragin sumnarized the influence of horizontal alinement on spot speed characteristics $(377,378)$ as follows: "Drivers of free-moving passenger cars do not change their speed appreciably after entering a horizontal curve. Any adjustment in speed that is made because of curvature or limited sight distance is made on the approach to the curve." As mentioned previously, the horizontal alinement of major streets assumes an insignificant role in affecting the operation and speed of traffic (1). Therefore, this discussion on horizontal alinement has been 
applicable to the non-intersectional areas of rural roadways. In intersectional areas the curves are necessarily of limited radil and length. When approaching an intersection, drivers anticipate sharp curves for turning maneuvers and accept relatively slow speeds for such movements.

\section{Vertical Alinement}

The vertical alinement of a roadway has a pronounced effect on vehtcular speeds. Passenger-car speeds are l1ttle affected by grades up to six or seven percent, but truck speeds are reduced by much flatter grades with the effect increasing as the grades become longer (132).

Several studies on the upgrade speeds of trucks have been reported in the literature. These speeds were determined by the hill-climbing abllity of commercial vehicles $(72,99,235,313,329,395,415,439$, 440). The gross welght of commercial vehtcles largely determines the speed of operation on grades. The sustalned speed over the ontire length of grade, termed "gradeability", is reduced by increases in gross vehicle welght and gradient. This speed reduction becomes more critical for heavier trucks as the length of grade increases. In a study made by C. C. Saal in $1938(305,306)$ it was concluded that: "...for motor trucks even to approach reasonable speeds on grades that: grades must be reduced to three percent or less; or engline power must be more than doubled; or gross vehicle weights must be reduced excessively; or some combination of the three must be used..."

In addition to the effect of gross vehfcle weight, the speed on a given grade is reduced almost linearly with an increase in the length of the grado until the crawl speed is reached. The truck then continues up 
the grade at this minimum speed $(133,135,305,306,312,361,379)$. Typical values of these speed reductions are as follows:

$\begin{array}{cc}\begin{array}{c}\text { Percent } \\ \text { Grade } \\ (\%)\end{array} & \begin{array}{c}\text { Speed Loss } \\ \text { per } 1000 \text { ft. } \\ \text { (mph) }\end{array} \\ 2 & \\ 3 & 2.0 \\ 4 & 5.0 \\ 5 & 9.5 \\ 6 & 15.5 \\ \text { (est.) } 7 & 23.0 \\ & 33.5\end{array}$

Estimated
Crawl Speed
(mph)

23.0

17.5

12.0

9.0

7.0

6.0

$(440)$

As shown above speed decreases at an increasing rate for steeper grades and/or heavier gross weights of the vehicles (133, 135, 182, 305, 306, 429).

The effect of momentum, which is directly proportional to the square of the velocity, is quite significant for short grades; therefore, the speed of a truck at the beginning of an upgrade will alter the operating speed on the grade. Thus, if the approach speed is relatively high the speed at the top of the grade will be greater than that resulting from a lower approach speed; provided, the gradient and/or length of grade are such that the crawl speed is not reached before the top of the grade (379). Average spot speeds on downgrades are increased for grades up to five percent for trucks and three percent for buses and passenger cars and reduced for downgrades in excess of these limits when compared to speeds on level tangent roadways $(250,257)$.

W. E. WHlley found in his study conducted in Arizona in 1949-1950 that sight distance and the drivers mental attitude, except under congested 
traffic conditions, largely controlled truck speeds on downgrades. Traffic congestion on narrow two-lane roads caused reduced truck speeds on downgrades, but altitude bad no apparent effect. He was unable to establish any correlation between downhill truck speeds and gross vehtcle weight, pounds per brake horsepower ratios, or percent of downgrade. This study further disclosed that trucks on downgrades generally have speed character1stics which are similar to those of passenger vehtcles on the same grades $(437,438,440)$.

Grades acceptable where traffic volume is 11 ght and passing is not restricted are not satisfactory where high traffic volumes reduced passing opportunities. Although the resultant speeds on grades may be less during high volume periods than duriag free-flow conditions, the greater portion of this reduction can be attributed to traffic volume (299). O.K. Normann (251) explained it this way: "...Grades have somewhat different effect on operating speeds than curves, but the primary reason that they reduce operating speods is because they generally cause certain restrictions on the sight distance. The fact that trucks travel at slower speeds on grades than on a level has a tendency to increase the number of passings required by a vehtcle tryling to maintain a certain speed, but if the s1ght distance was not also reduced by the exdstence of the grade, the reduced speed of the truck would have only a slight effect on the operatIng speeds of the other rehicles."

B. A. Lefere was unable to find any consistent relation between operating speeds at the crest of vertical curves and the mintmum sight distance (177). It has been further concluded that speeds at vertical curves, regardless of the slght distance, are apparently governed by the normal speeds on the highway preceding the curve $(177,336)$. 
The speeds of commercial vehicles on a grade are dependent on many factors, the most important ones being gradient, length of grade, gross vehicle weight, approach speed, and power of the truck.

\section{Passing Sight Distance}

Sight distance has been discussed previously as related to horizontal and vertical alinement for a particular location. However, thls did not Include a discussion of passing sight distance and the restrictions it imposes on traffic over a given length of roadway. In considering this effect on speed as measured over sizeable lengths of two-lane highways in rural areas, observations have indicated that vehicular speeds decrease as the percentsge of sight distance less than the passing sight distance increases $(133,222,251,312)$.

Becsuse restricted sight distance limfts the number of opportunities to pass, the actual operating speed is determined by the combined influence. of traffic volume and the percentage of the total roadway length which has insufficient sight distance to permit passing maneuvers (133, 251, 312).

\section{Cross-Section Elements}

Cross-section elements of the roadway for the purposes of this study Include the number of lanes, lane width, lane position, road surface, medlans, curbs, shoulders, lateral clearance, friction points, and speed change lanes.

\section{Number of Lanes}

In general, four-lane highways, on which passing is not restricted by opposing traffic, have higher average opot speeds than two and three-lane 
highways. The average speeds on four-lane divided highways are somewhat greater than those on four-lane undivided highways $(69,120,250,257)$. However, a study conducted by P. J. Claffey in 1959 In 17 eastern states showed little difference between space mean speeds on two-lane roads and four-lane roads, excepting that four-lane major urban routes outs1de of the downtown areas of major clties had speeds approxdmately 25 percent higher than two-lane routes in the same cities (45). Several reports have indlcated that average spot speeds on three-lane facllitles are slightly higher than on two-lane facllities $(8,250,257,299)$. However,

a comprehensive speed survey conducted in Canada in 1956 indicated that three-lane highways may have Iower mean speeds than two or four-lane facilities (75). It is generally agreed that roadways with more than four-lanes have speed characterlstics similar to those for four-lane facilities $(299,397)$.

\section{Lane Width}

Some disagreement appears among the findings of studies concerning the effect of lane width on speed. Speed surveys conducted in New York In 1950-1951 revealed that the average spot speeds of cars Increased 0.3 mph, and the average spot speeds of trucks increased 0.2 mph for each additional foot of parement over 20 feet (427). A study conducted by R. E. Frost in Indians in 1941-1942 found that cars traveled somewhat Paster on 22-foot parement than on 18-foot pavement under good weather conditions, but that pavement width had no apparent effect on speed when bad weather was encountered (98). On c1ty streets in London a speedvolume-lane width relationship was established for street wdths equal to or greater than 20 feet and speeds greater than $10 \mathrm{mph}$. This relationship 
was generalized by the equation: $S=31-(V+430) /(3 W-18)$ or to 24 mph whichever was less, where $S$ is the average spot speed in miles per hour, $V$ is the volume of traffic in vehicles per hour, and $W$ is the total pavement width in feet. In other words, average speeds in urban areas decreased Iinearly with increasing traffic volumes, but this reduction was less for wider streets than for narrower ones (425).

Extensive rural speed-placement studies conducted by the Public Roads Administration (now Bureau of Public Roads) in cooperation with several State Highway departments in 1943-1944 (380, 381, 383) reported that: n...for the sections included in this study on which vehicle speeds were typical of modern two-lane highways, pavement width apparently had no consistent effect on the average speeds of either the free-moving vehicle or those meeting on-coming traffic....

"Perhaps the most important consideration is that drivers did not travel more slowly on the narrower than on the wider surfaces. This should not be interpreted to Imply that the narrower surfaces are as adequate for the desired speeds as are the wider roads. It is more likely that drivers maintain their desired speeds in the face of an apparently greater hazard on the narrow wldths." Other studies conducted in more recent years have been unable to establish any delinite correlation between vehtcle speeds and lane width $(191,319,346)$.

In general, for maln two-lane mural highways it can be concluded that very slight increases in speed with increased pavement width will probably occur. 


\section{Lane Position}

Another varlable of the highway cross-section which has recelved considerable study is lane position. A. Taragin, in his study of driver performance on horizontal curves on two-lane rural highways, concluded that even though the sight distance in mang cases was greater for the outisde lane than the inside lane, the average speed on the outside lane on curves was about the same as that on the inside lane $(377,378)$.

On three-lane highways the two outside lanes show the normal linear decrease in average speed with an increase in volume, but the center lane shows a higher average speed than the outside lanes, and the speed does not appear to change with variations in the traffic volume (133, 250, 257$)$.

A number of comprehensive speed studies made on multilane divided facilities have included observations of speeds by lane position. These studies have shown that the slower average speed occurs in the right lane and that the highest average speeds occur in the median lane. The slower speeds in the right lane are attributed, in part, to the presence of commercial vehtcles which tend to travel in this lane, and by the usual speed-change maneuvers of Ingress and egress traffic in this outside lane. The faster speeds in the median lane can also be partially attributed to the through traffic (discussed under Traffic Stream Characteristics) which tends to travel in this lane to avold the hazards of merging and diverging traffic which normally takes place in the right lane $(91,162,163,185$, $193,195,196,228,319,421,431)$.

\section{Road Surface Type}

Speeds tend to increase as the type of road surface progresses from low to high (299). However, different road surfaces of a comparable type, 
such as bituminous concrete and portland cement concrete, have similar speed characteristics $(271,419)$.. In Connecticut in 1937 average speeds on concrete highways were found to exceed those on lower type pavements by three to four mph (396). In studies made in Indiana in 1933 and again In 1934 on the same sections of roadway, it was found that the average speed on monollthic brlck surfaces (which were rough and nolsy) were nine to ten mph lower than that for concrete surfaced roads (271). Several studies conducted in different states during the 1930 's showed speeds on gravel surfaces to average about elght to ten mph lower than those on concrete roads (111, 113, 121, 234, 268).

\section{Medians}

A background of farorable experience in the use of medians has resulted In the acceptance of the separation of opposing lanes as an essential feature of a multilane highway $(28,181,270)$. Kany trafflc surveys have reported higher average speeds on divided than on undivided roadways in both urban and rural areas $(192,250,257)$. Speed data collected in New York in 1950 on six different median types showed that average speeds of vehicles were not affected by the type of median (28).

However, it has been shown that the placing of a median in an exdstIng four-lane facility without providing any additional pavement width w1II produce a "squeez1ng" effect on traffic and speeds will be reduced. Th1s presents the faster moving vehicles with a situation in which they more often choose to slow down and follow the slow moving vehicle than to pass (268). 
Curbs

Little study. has been made of the effect of curbs on traffic speeds. The presence of mountable curbs alone does not materlally reduce average speeds, but barrier curbs tend to reduce average speeds by two to three mph, unless additional lane width is provided to compensate for these curbs (191).

\section{Shoulders}

Studies have been made and data analyzed according to different types and widths of shoulders. The majority of these studies indicate a slightly higher average speod for the highway with a shoulder than for the highway - with no shoulder, but that speeds are not significantly influenced by wide shoulders or shoulder type $(300,319,375,376,384)$. Studies conducted in Ohlo and West Virginla Indicated a slightly higher speed for wide shoulders; however, the conclusion was drawn that for the conditions studied variations in shoulder width and type had but little asurable effect on the speeds of free moving vehicles (300).

A. Taragin and H. G. Eckhardt sumarized data collected at more than 50 locations in 15 states (384) and offer the following conclusions: "The speed of moving vehicles is not subetantially affected by the width of shoulder, providing the shoulder is more than 4-ft. In width, and wellmaintalned grass shoulders have the same effect on the speed and lateral position of moving velficles as does well-maintained gravel shoulders.".

\section{Lateral Clearance}

In general, travel characteristic studies hove disclosed a reduction in vehicular speeds when restricted lateral clearsnces were produced by 
placing objects on the roadway shoulders. The type of object producing the restricted lateral clearance, its location on the shoulder, or the pavement width made IIttle difference in speed characteristics $(261,319)$. In 1953, A. Taragin in a study of driver behavior as affected by objects on roadway shoulders $(373,374)$ provided some refinements to these conclusions. He found that passenger cars traveling in the lane adjacent to the occupled shoulder on two-lane pavements 16 and 20 feet w1de reduced their speed an average of three $\mathrm{mph}$, and on pavements 22 and 26 feet wide reduced thelr speed an average of one mph. He also found a greater tendency for speeds to be reduced when a barrlcade was placed on the shoulder than when a truck or passenger car was parked on the shoulder. He further concluded, "...truck drivers, regardless of the lane in whtch they were traveling, were influenced by the shoulder condition even less than passenger car drivers.

"The average passenger car driver, meeting another vehtcle traveling In the opposite direction at the same place on the highway as the object was located on the shoulder, reduces his speed 2.3 miles per hour if in the lane adjacent to the occupled shoulder, and $1.5 \mathrm{mlles}$ per hour if in the other lane....

non the four-lane highway there was no conslstent tendency for drivers of vehlcles in either lane under any of the study conditions to change their speeds with respect to those under normal conditions."

Results of several observations at narrow bridges tend to ind1cate that plate-glrder bridges 24 or more feet wlde cause little or no reduction in speed on two-lane roads while those less than 24 -feet w1de produce a definite reduction in speed $(98,285,448)$. On the other hand, lons, 
high truss bridges 24-leet wide showed reductions of about seven miles per hour below the speed on adjacent tangent sections (191).

\section{Friction Points}

For purposes of this discusaion frlction points will include hlghway Intersections at-grade, at-grade railroad crossings, and school zones ( 153 , $161,191,192,218,342,449)$. Several authors have presented methods for determining the critical approach speed at uncontrolled intersections $(58,115,145,288)$. Bruce D. Greenshields developed the equation, $S=15+0.12 \mathrm{~V}^{2}$ wh1ch gives the minfmum distance $(S)$ required from the collision point to the decision point in terms of the speed (V) at the.. decision point for uncontrolled intersections (P1gure 2) (115).

F. D. Miller in his study of school crossings in Indlana found that the presence of chlldren at the edge of the rosdway lowered the 85th percentile speed three to four miles per hour. The reduction was greatest In the lane adjacent to where the children were standing $(82,218)$.

There is generally belleved to be a tendency for spot speeds on roadways to decrease with an increase in the number of friction points encountered per unit of distance, but very little information is avallable concerning this subject. P. J. Claffey observed that on roadways with less than two crossroads per mile, average speeds decreased with an increase in the Irequency of driveways. These observations were based on zero to ten, ten to 20 , or more than 20 driveways per mile. When the number of crossroads was greater than two per mile, average speeds increased slightly with an increase in the frequency of driveways from zero to ten and ten to 20 per mile, but arerage speeds dropped abruptly for a frequency greater than 20 driveways per mile (45). 


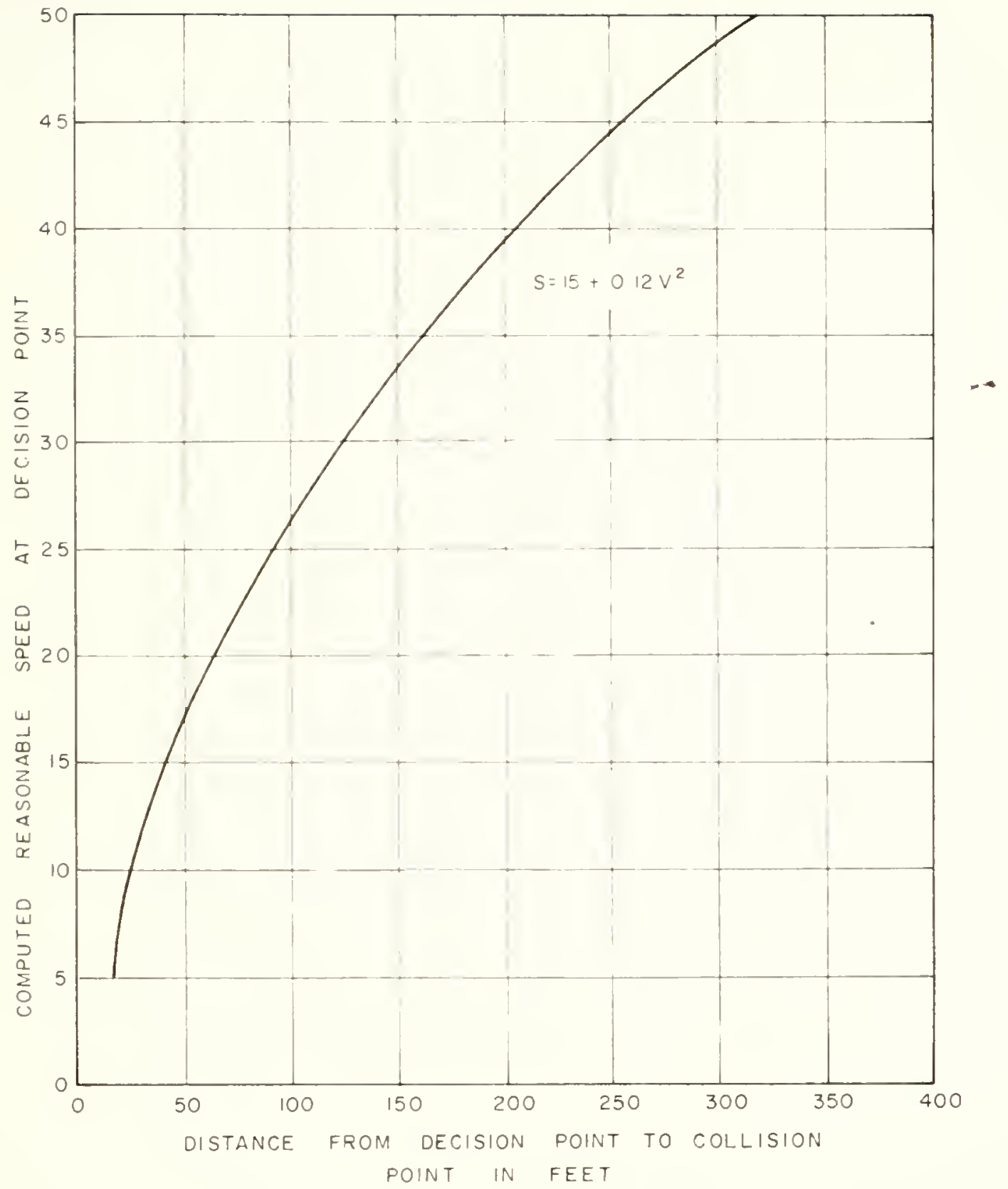

FIGURE 2 - MINIMUM DISTANCE FROM COLLISION POINT TO DECISION POINT FOR THE MINIMUM TOTAL DELAY FOR VARIOUS MIOBLOCK SPEEDS AT A NON-CONTROLLED INTERSECTION 


\section{Speed Change Lanes}

Deceleration lanes provide a place for turning vehicles to slow-down without affecting the through trafflc. Iikewise, the acceleration lane provldes a place for vehicles entering high-speed highways to gain their speed and pick a gap for merging whout intermpting the through traffic. Studies were made in the early stages of speed-change lane development concerning the weaving and merging pract1ces of vehicles to provide the needed information to design these facilities (221, 370, 371, 451). More recent studies have been made in an attempt to determine the optimm lengths of acceleration and deceleration lanes $(159,314)$. It has been concluded that, in general, trafflc on properly designed acceleration or deceleration lanes has little effect on the speed of through traffic on multilane fac1lities (159). 


\section{TRAFFIC STREAM CHARACTERISTICS}

From a purely theoretical standpoint, volume, speed, and density are the basic elements of traffic llow. The fundamental mathematical relationship for flowing traffic is: $V=S D$, where $V$ is the average volume in rehicles per hour, $S$ is the average speed in miles per hour, and D is the average density in vehicles per mile (112, 114).

\section{Speed, Volume, and Density}

From the above expression it is seen that volume has a very definite effect on vehicular speeds. If a driver is to proceed at a desired speed, he must have unlimited opportunities to overtake and pass on two or threelane highways, and on multi-lane roadways he must be able to change lanes and pass as he desires. Nmerous studies conducted over the jears in several different states have reported an apparent linear relationship between traffic volume and average speed for a glven type of roadway, other conditions being the same, until near capacity conditions are reached $(8,17,37,49,50,77,133,161,195,196,250,251,253,256,257,259$, $260,312,411,423)$.

In an investigation of traffic congestion in Melbourne, Australla in 1956 the following regression equations for speed-volume relationships were reported: $S=44.5-1.03 \mathrm{~V}_{1}$ for a suburban area with a coefficient of correlation of -0.91 , and $S=44.9-1.27 \mathrm{~V}_{2}$ for an urban location with a coefficient of correlation of -0.90 , where $S 18$ the mean speed in miles 
per hour, $V_{I}$ is the volume in hundreds of vehicles per hour for both directions of travel on two-lane roads, and $\nabla_{2}$ is the volume in hundreds of vehicles per hour for one direction of travel on four-lane rosds. The author stated, however, that "The wide range in volumes encountered during this fleld study covering a limited time did not produce a sufficlent number of speed samples at many levels of volume to give statistically signiflcant results." This is a possible explanation for the high correlation coefficients obtained $(103,104)$.

O. K. Normann in a study in 1943 reported the following equations for two-lane, rural highways; $S=43-0.009 \mathrm{~V}$ for small percentages of commerc1al vehicles, and $S=43-0.012 \mathrm{~V}$ for trucks equal to 17 percent or greater, where $S$ is the average speed in miles per hour and $V$ is the volume in vehicles per hour. The equation for high-speed highways was found to be $S=48.5-0.009 \mathrm{~V}(251,259)$.

At trappic densities greater than the critical density (that density at which possible capacity is attained) both volume and speed are reduced. This relationship is depicted on the graphical diagram in Figure 3. As densities increase bejond the critical density, average speed decreases at a decreasing rate with a correaponding reduction in traffic rolume, and both become zero where density is greatest (bumper to bumper) but where there 1s no traffic flow (112, 114, 116, 133, 150, 256, 267, 312, 411, 423). As a result, except at the point of possible capacity, there are two possible average speeds for a volume, depending on the traffic dens1ty. The higher average speed on the upper portion of the graph results when the traffic density is below the critical value, and the lower average speed on the lower section of the plot denotes the rate of traffic movement if the critical density is exceeded (114). 


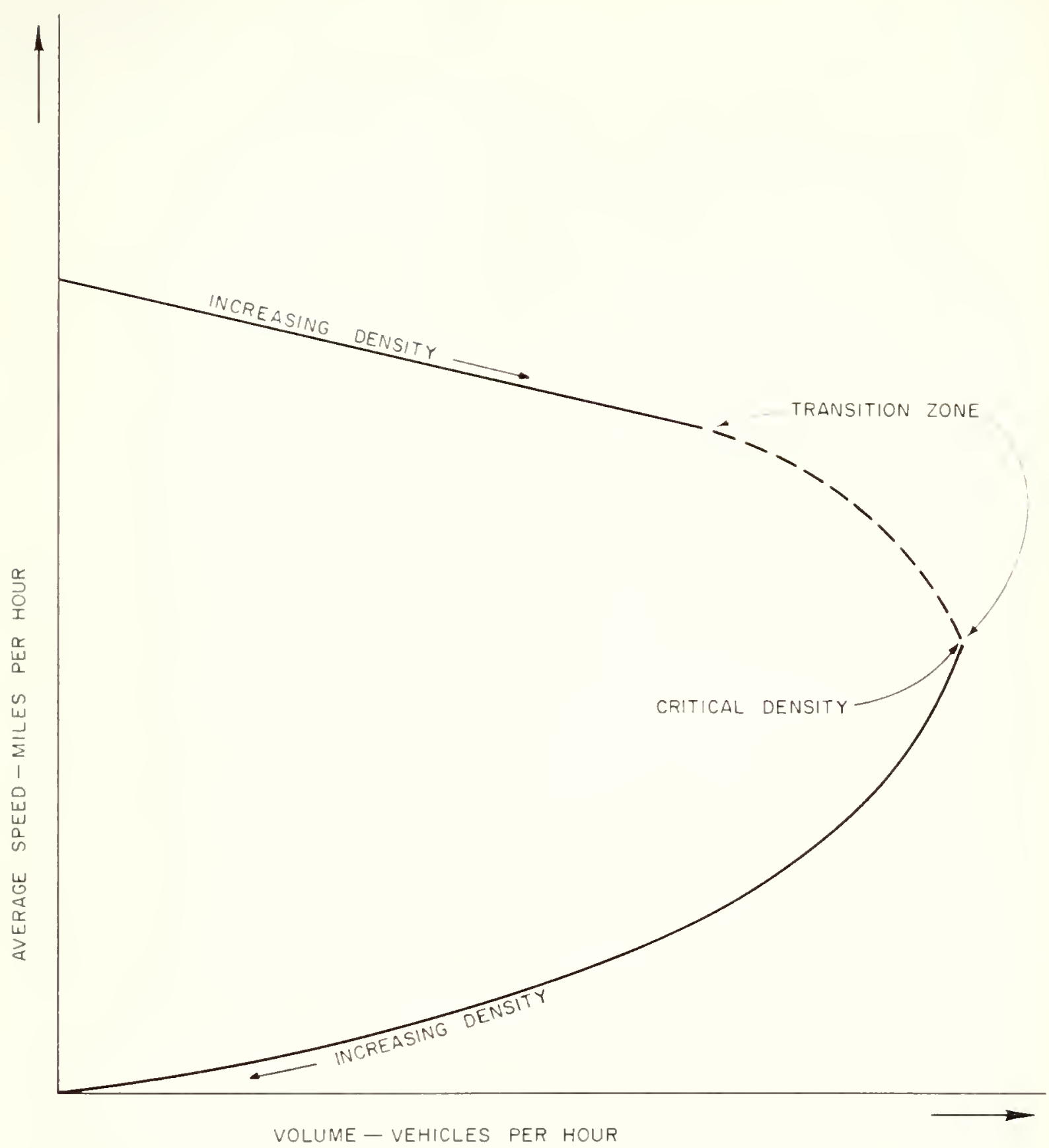

FIGURE 3 - GENERAL SPEED-VOLUME DIAGRAM 
From data collected in Ohio in 1934 B. D. Greenshlelds found a negat1ve sloping linear relationship between average speed and average density for densities less than the critical density (108, 112, 14). A fleld study of traffic Plow on the Merritt Parkway conducted in 1956 supported this linear correlation between speed and density $(150,267)$. However, a study made on this same facility in 1960 showed an exponential relationsh1p between average speed and density, with speed decreasing at a decreasIng rate for increasing values of dengity. In this 1960 study R. T. Underwood (411) further stated: "Tor volumes and densities up to, and well beyond, the practical capacity, the speed-volume and speed-density curves closely approximate straight lines and, for practical purposes, could be taken as such. The speod-volume curve deviates considerably from a straight line as the possible capacity is roached, but the speed-density curve is still reasonably close to a straight line up to the possible capac1ty; although beyond this limt, errors by use of a stralght line would tend to become large."

Several investigations on hlghwaJ operating characteristics, part1cularly on freeways, have reported a parabolic relationshlp between speed and rolume. The drop in speed with increasing rolume was very slight unt1l a sharp down-break occurred some distance before the possible capacity was reached. The speed-volume relationshlp for densities greater than the critical value was in all cases approxdmately the same as the relationship discussed earlier $(91,116,150,162,185,228,256,267$, 411, 431).

A series of curves relating speed to the ratio of volume to capacity for signalized urban arterials were developed for use in the Chicago Area 
Transportation Study. The Poisson distribution was used to generate vehicle arrival rates. From this, the average speed on a particular roodway facillty was found to remain relatively constant as the rolume-capacity ratio Increased to 60 percent for signillzed streets and to 80 percent for rural and urban freeways. As the ratio increased beyond these respective Iintts the speed was observed to decrease Iinearly (35).

R. T. Underwood in his study of speed, volume, and density relationships, proposed a general speed-volume relationship in which traffic Plow Is subdivided into three separate zones - - "A zone of normal flow, a zone of unstable flow, and a zone of forced mow --- each zone being specified in terms of probabilities." For the zone of nomal Nlow a linear relationship was assumed to exist between speed and rolume on the basis of prevlous relationships noted by many researchers in this area. He stated that no definite relationship probably exdsted between speed and rolume in the zone of unstable flow. Flow cannot be maintained at a constant rate for any length of time in this zone. Rather it is a transition between the zones of normal and forced flow (4II). Curves produced by Palmer (267) also Indicated the presence of an unstable area in the vicintty of possible capacity, and one of O.K. Normann's later papers (256) Indicated the possibility of an unstable condition at possible capacity.

Underwood's proposed speed-volume relationship was found to be fairly consistent with the observed data of T. W. Forbes (91) A. D. May, Jr. and F. A. Wagner, Jr. (196), M. R. Palmer (267), and G. M. Webb and K. Moskowitz (431). It was also "reconciled" with the models of B. D. Greenshields $(112,114)$ and $0 . K$. Normann $(256)$, and at the same time 1 t seems to orercome their apparent defictencles (4II). 


\section{Longitudinal Distribution}

The longltudinal distribution of vehicles in the traffic stream affects the driver's selection of speed (191). Average headway, the average time interval between the passage of succossive vehicles going by a fixed point, is a direct measure of, and inversely proportional to, volume. Several fleld observations of traffic-stream characteristics have considered the influence of headways between vehicles on average speeds. In general these studies have concluded that there is little or no difference in the speeds of successive vehicles until headways are reduced to some critical value within the range of three to nine seconds. When headways decrease below this critical value, the speed of the following vehicle decreases rapidly until the same speed as that of the lead vehicle is reached ( 91 , $133,253,257)$.

A headwry of four seconds was found to be the critical time-spacing value for data collected at a temporary bridge on the Merritt Parkway in Connecticut. The rear vehicle was often the faster at headways above four seconds, while at a time spacing of four seconds or less it was usually traveling slower than the vehicle in front (267). O. K. Normann in one of his reports (253) stated that: "...the average driver starts to be influenced by the speed of the preceding vehicle at a fairly constant time spacing or at a distance spacing that varies with his speed."

T. W. Forbes in his analysis of data collected on a six-lane freeway In Calffornia suggested that: "...drivers are not necesearily affected by the car ahead at a given time spacing, and that a nine-second figure previously reported for two-lane highways probabls resulted from the restriction of passing opportunities." He also reported that drivers under 
the pressure of very heavy traffic, tended to maintain a fixed minimum distance rather than a minimum time separation, with the minfmum distance maintained being proportional to the speed at which they were traveling (91).

\section{Passing}

In order for the faster moving vehicles to maintain their desired speeds there must be adequate opportunities for them to change lanes and pass the slower-moving vehicles. Several studies of passing maneuvers were made in the late 1930 s, and all of them are in fairly close agreement $(93,109,143,190,232,254,279,383)$. One study reported that 84 percent of the drivers desiring to pass had to slow down before the passing maneuver was made (232). C. W. Prisk did an extensive investigation of passing practices on rural highways from 1938 to 1940 (279). He reported the influence of passing maneuvers on vehicular speeds as follows:

"1. The average passing driver wants to travel approxdmately ten mph faster than the vehtcle he passes and about six mph paster than the average speed of all traffic.

2. The passing vehfcle, on the average, slows down before passing to withtn five mph of the speed of the vehicle to be passed.

3. The normal or desired speeds of the passed and passing vehicles are approximately the same as their average speeds during the passing.

4. There is no apprectable change in the speed of the passed vehicle during the passing. 
5. The average maximum speed attained by the passing vehtcle during the maneuver is three to four mp above its normal drlving speed and about ten higher than the average for all traffic on the highway."

A. Taragin reported that on two-lane highways the average speeds of the passing veh1cles ranged from 45 to $52 \mathrm{mph}$, and speeds of the passed vehicles averaged between 32 and $37 \mathrm{mph}(381,383)$. O. K. Normann has reported that paseing practices have changed very little over the jears. In a study conducted In 1938 he found the average speeds of passing vehicles to be $45 \mathrm{mph}$, average speeds of passed vehicles were $35 \mathrm{mph}$, and average speeds of free-moving vehtcles were $4 \mathrm{lmp}$ (254). In a repeat study conducted in 1957 the average speeds were found to be 52 mph for passing vehicles, 39 mph for passed vehicles, and $45 \mathrm{mph}$ for free-flowing vehtcles (383).

\section{Traffic in the Opposing Direction}

Several fleld investigations of speed characteristics on rural, twolane highways have included information on the effect of opposing traffic on spot speeds. A. Taragin in his analysis of data from ten states ( 380 , 381) reported: "...1t is interesting to note that the speed of the average driver is practically the same when meeting oncoming vehicles as when uninfluenced by other vehicles." However, in 0 . K. Normann's study of highway capacity in 1934-1935 opposing traflic was found to have some influence on vehicular speeds. In a regression analysls correlating the speed of the vehicles wth the volumes of traffic in the same and opposing directions, the following multiple linear equation was produced with a correlation coefficient of $-0.877: S=44.92-0.01044 v_{s}-0.00719 v_{0}$. 
where $S$ is the average speed in one direction in miles per hour, $\nabla_{S}$ is the traffic volume in one direction in vehicles per hour, and $V_{0}$ is the opposIng traffic volume in vehtcles per hour. Of course, this expression is valid only for two-lane rural highways having a density equal to or less than the critical value $(253,268)$.

\section{Driver Residence}

Driver residence, in general, has been classlfied as in-state or outof-state for purposes of analyzing speed data. A study conducted on rural, two-lane highways by C. H. Lawshe, Jr., in 1940 compared the speeds of drivers having rural addresses with those having street addresses. He reported a mean speed of $39.9 \mathrm{mph} \pm 0.97$ for drivers with maral route addresses and a mean speed of $45.5 \mathrm{mph} \pm 0.53$ for drivers with street addresses. He concluded that this difference of 5.6 mph was statistically signteicant (175).

Several speed characterlstic studies have produced data which has shown that out-of-state cars are driven faster than in-state cars (65, $71,83,101,142,268,333,346,396)$. H. R. DeSilva in a study of drivers In Connecticut found that, on an average, out-of-state men drove $3.1 \mathrm{mph}$ faster than Connecticut men, and out-of-state women drove $3.2 \mathrm{mph}$ faster than Connecticut women (65). From a study of driver characteristics in the daytime in Californta, O.K. Normann found that out-of-state men traveled 2.3 mp faster than Calfornia men, but out-of-state women traveled 1.9 mph slower than the Callformia women (252). C. H. Lawshe, Jr. In a study conducted in 1940, concluded that in-state or out-of-state residence Itself is not a factor and that those who were observed more than 25 miles 
from home may be combined with the out-of-state group (175). In a more recent study conducted in Illinois by J. C. Oppenlander (264) it was found that on four-lane highways drivers residence apparently had little Influence on speed characteristics. However, for two-lane facilities he concluded: "The mean speeds of out-of-state and in-state passenger vehlcles were significantly different....... in all areas."

Several authors have reported trip distance as one of the most Important factors affecting driving speeds $(66,67,135,142,396)$. The following statements from the 1940 study of driver characterlstics in California (252) indicates that it is trip distance rather than residence which affects speed: "There is not a signiflcant difference between speeds of out-of-state drivers and California drivers for corresponding travel d1stances." This report further stated that drivers going over 400 miles traveled significantly faster and drove newer cars than those going less than 20 miles. Also: "...regardless of the age of the vehicle, the average speed increases with an increase in travel distance. The newer the vehicle, however, the greater is the relative increase in speed. The rate of speed increase is much greater for the shorter travel distances, especially those below 75 miles, than for the longer travel distances." H. R. DeSilva found that drivers who had traveled short distances were driving at slower speeds than drivers who had traveled long distances, and drivers who st1ll had long distances to go traveled faster than those who were near their destination $(65,66)$. It was reported by C. H. Lawshe, Jr. In 1940 that those rural people who were further than 25 miles from home did not differ a great deal from urban people in so far as speed is concerned (175). 


\section{VARIATION WITH TIME}

Variations in vehicular speeds have been analyzed according to the varlous time cycles of jear, season, month, day, and hour. The yearly varlation has been discussed previously under "Speed Trends".

\section{Seasonal}

C. J. Tllden in a study in 1936 observed that the average speeds of passenger cars and buses were highest in the winter and lowest in the summer, and truck speeds were lowest in the summer, and that they were slightly faster in the spring than in the winter (396). A study conducted In Minnesota in 1961 showed the 85th percentile speed of all vehtcles to be one to two mph faster in the fall than in the spring and summer $(62)$.

\section{Monthly}

A study of the variability of fixed-point speed measurements in Wisconsin concluded that the difference between monthly mean speeds was larger than could be accounted for by chance (322).

\section{Da11y}

There is little consistency in the reports regarding dally fluctuations in spot speeds; however, most of them agree that Sunday speeds in general are lower then those observed on other dajs $(67,74,209,271$ ). One study 
reported a real and significant difference between Monday, Tuesday, Thursday, and Friday mean speeds (322). Another study reported, for one study location, that speeds on Wednesday were slower than those on any other weekday (67). Still another study (209) reported: "...there appears to be no slgnificant difference between various days of the week, with the exception of the morning hours on Tuesdays. ...This warrants further investigation." No apparent trends are reflected in the above studies; therefore, it is believed that it is the difference in traffic stream character1stics rather than the day of week which accounts for the speed vartations.

\section{Hour of Day}

The variation of speed patterns with the hour of day is also subject to disagrement. A study conducted in IIIlnois (262) concluded: "...results of statistical tests showed that the variation of spot speeds with time of day were not consistent with respect to both time of the day and locations along the study route." Some studles have indicated a definite time-speed variation during the 24 -hours of the day, and this difference cannot be accounted for by change alone $(209,322)$. One study reported no difference in speeds by hours of the day between 10:00 am and 5:00 pm (175). Other studies found that speeds vary little with time of day (17, 302, 435). St1ll others have shown that the average speed decreased as the day progressed. Relatively high speeds occurred in the early morning business hours, then decreased gradually until late afternoon, rose to a minor peak between flve and seven pm, decreased rather sharply at dusk, and continued to decrease gradually to the lowest average of the day after 
night fall $(117,209,333,346,396)$. N. J. Rowan and C. J. Keese, in their study of factors influencing traffic speeds (302), reported that: "The highest traffic speeds were observed during 1) extremely low volume conditions in the late evening and early morning hours, and 2) rush hour periods when the driver was operating on a tight schedule. A large number of traffic conflicts resulted in a reduction in traffic speeds." There is sufficient infornation presented above to suggest that a significant varlation in vehicular speeds occurs during the day. There are also indications that the reported variations may have been primarily due to stream characteristics which differed during the day rather than to the time of the day.

\section{Day vs N1ght}

By observing vehicular speeds for both day and night the effect of light conditions on driver operations can be measured. Several speedcharacteristic studies have shown no significant differences between daytime and nighttime speeds $(8,28,268,284,346,355,380,381,383)$. Many other articles written on highway travel characteristics have indicated that average speeds at night are about one mph lower than in daytime on urban arterials $(30,64)$ and two to elght mph lower in rural areas. The range (two to eight $\mathrm{mph}$ ) for rural areas occurs on different types of roadway facilities $(74,98,121,209,275,276,285,342,396$, $442)$.

\section{Illumination and Delineation}

Dlumination and delineation are aids to night visibility on the highway, which had prevlously been limited to the range and adequacy of 
the vehicles headlights. In 1939 an investigation of driver behavior under night travel conditions demonstrated that average night speeds were lower with or without highway illumination than average day speeds. Average ndght speeds were also found to be slightly less with illumination than with no 1llumination $(70,188,422)$. In 1944, the Bureau of Publlc Roads conducted a limited study on rural, tangent highway sections in New Jersey. These studies indicated little change in night driving speed between lighted and unlighted sections (258). A. Taragin and B. M. Rudy recentiy reported the results of studies conducted on the Connecticut Turnpike. They could not determine any significant difference in average speeds for various copditions of illunination and delineation $(385,386)$. A falriy extensive study conducted in Indiana in 1959 considered the effect of roadside reflectors, pavement edge lines, signing and, in one case, channelizing islands on driver speed patterns. The results of this study indicate that with added delineation, the average speeds of passenger cars at night showed a tendency to be slightly higher, particularly at critical points such as a narrow bridge, the center of an intersection, or on sharp curves. However, these speed increases were very small (less than $11 / 2 \mathrm{mp}$ ) and probably were of little practical significance ( 275 , 276). From these studies it appears that illumination and delineation have very little affect on the average speeds of vehicles. 
WEATHER CONDITIONS

Vehicular speeds tend to be affected by weather conditions due to a reduction in Visibility or Impairment of surface conditions. In general inclement weather tends to lower spot speeds, with the amount of reduction varying with the severity of the conditions $(98,185,186,268,423)$. C. J. TIlden observed reductions in average speeds due to impaired visibillty to range from 7.5 percent in 11 ght rain to 23 percent in dense fog, under unfavorable road surface conditions to range from 4.4 percent on a clear day with the surface 30 percent snow-covered to 37.5 percent on a clear day with three inches of hard-packed snow on the surface, and with both impaired Fisibillty and unfavorable road surface conditions to range from 10.3 percent during snow flurries with snow on the road to 23.5 percent during a sleet storm with the surface 1cy (396). He summarized the effects as follows: "... The effect of weather on speed ranged from stopping altogether during bad snowstorms to driving at high speeds on clear, crisp mornings when the road was free from snow or 1ce." It appears that bad surface conditions (hard-packed snow) create greater speed reductions than do lower visibility conditions $(67,191,396)$. R. E. Frost reported that the only weather conditions affecting traffic speeds, during his surrey, were hard rains or heavy snows which greatly reduced visibility (98). T. W. Forbes and M. S. Katz reported that rehfcular speeds were reduced on snowy or Icy parements, but not to the extent necessary to compensate for the adverse operating conditions (92). 
The ifterature is somewhat inconsistent as to the effect of wet pavement on vehicular speeds. Some reports have indicated a reduction in veh1cular speeds on wet pavements, $(186,325)$ whlle others have shown no significant difference $(188,352,365,396)$. R. J. Smeed reported (325, 326): "The speeds of rehicles on wet roads have been found to be slower than those on the same roads when dry if the road looks slippery when it is wet, but not so, if it does not look slippery; In that case the average wet road speed was about the same as the dry road speed, even if the road was actually slippery." These studies reveal that in general the motoring public tends to adjust its speed to the relative danger of road hazards encountered. 
SPEED CONTROL MEASURES

Various types of traffic-control devices and techniques are employed in an attempt to regulate the flow of vehicles. Some of these devices and techniques have been favorably accepted by the general public whlle others have caused considerable discussion and disagreement.

J. E. Johnston so aptly described the s1tuation as follows (157): "Ever since the first automobile chugged its noisy way among the startled horses and amazed public, the motor car has been subjected to every restrictive trapplc law concelved by man. There has been a concerted effort to curta1l its movements with stop slgns, traffic signals and speed limits. This attitude is already costing us much of the advantages we might gain from improved automoblles and highways. Unless we think more in terms of 'go' than 'slow' in drafting regulations, it is going to cost more."

\section{Controlled Access}

The control of access to roadways is a technique being employed not so much to control speed but rather to permit higher speeds with greater salety (197). It is a prerequisite in the design of most modern freeways and expressways. In 1954 a study was conducted by A. D. May, Jr. in an attempt to determ ne the effect on speed of full, partial, and no control of access in urban, suburban, and rural areas. The extent of access control apparently had little influence on spot speeds in rural areas, but In suburban and urban areas the average speed was found to increase with 
increasing control of access. This study reported that average speeds on fully controlled-access facilities in rural, suburban, and urban areas were, respectively; $2.5,10.3$ and $20.9 \mathrm{mph}$ higher than average speeds for corresponding areas on uncontrolled-access roadways (194). P. J. Claffey in his investigation of the characteristics of passenger-car-travel on toll roads and comparable free roads reported an average speed of 60.1 mph on rural four-lane diflded controlled-access routes and an average speed of 48-50 mph on two and four-lane rural routes without control of access (45).

\section{Enforcement}

Several studies have been conducted in an attempt to deternine the effect of enforcement activities on vehicular speeds. Pilot studies were conducted at the Traffic Institute, Northwestern University in an attempt to determine the affect of a visible patrol unit. The data suggests some slowling of traffic in the immediate vicinity of a standing patrol unit. The data for the patrol unt moving in the traffic stream indicated that the effect of the unft was limited to 1,000 feet or less ahead and only a few hundred feet behind it (18). A special study conducted in Chicago reported (4): "Somewhat more than doubling arrests for hazardous traffic law vlolations results in slightly less than halving the excess speed per vehicle. The death rate also dropped but not quite so much. Night speeds responded more to the additional enforcement than day speeds did." Other studies have reported reductions in the auto death rate with increased enforcement $(139,296)$; however, these did not mention a reduction in speed. Several reports have indicated a reduction in speed after the 
placing of slgns indicating that a timing device is being used (3, 136, $208,277,286,310,391)$. Seattle, Washlngton has reported that (412): "...an oversize speedometer mounted on the rear of police cars, and showIng the true speed of the cars, had a noticeable effect on speeding in Seattle." No after studies are reported to show 11 these are permanent reductions or if speeds are just reduced temporarily and then return to their original values. N. J. Rowan and C. J. Keese reported (302): "Trafflc speeds are reduced in the immediate vicintty of radar enforcement activity. The locallzed influence of enforcement has essentially dissipated at four miles on elther side of the radar unit." It is generally inferred that on rural hlghways increaging enforcement caused no 8 ignificant decrease in average spot speeds $(156,211,320,321)$. Some atudies indicated that vehicle speeds tend to group more closely around the average (decrease the varlance) when the level of enforcement $1 \mathrm{~s}$ Increased $(211,321)$. 0. K. Normann reported that average apeeds on freeways with Ittle or no enforced speed Ifmits were higher than those for freeways with well-enforced speed limits (256).

\section{Traffic Stgnals}

Vehtcular speeds apparently are influenced to different degrees by the presence of traffic signals depending on the type of signal, the signal timing, and the frequency of signals. A study in Connecticut on a fourlane, divided highway with at-grade intersections revesled a decrease in speed after s1gnals were 1nstalled. The average speed before the installation of traffic signals was 49 miles per hour. A progressive gignal system wa installed in 1951, and the average speed dropped to approximately 
45 miles per hour (138). Other studies have indicated that average speeds on major streets were increased by changing the signal system timIng from simultaneous to progressive $(37,118,436)$. Traffic signals of the pretimed type cause a reduction in speeds on roadways in both rural and urban areas $(138,171)$. However, the use of flashing beacons apparentis has no significant effect in reducing approach speeds of vehicles at intersections (427). In an investigation of the relation between speed and volume on urban streets in Chicago, a negative, Ilnear relationship was produced between the number of traffic signals per mile and the average speed (16I). The effect that traffic signals have on vehicular speeds tends to vary widely between different roadway paclifities and different types of signal systems (423).

\section{Traffic Signs}

The use of "slow" signs to warn motor-vehicle operators has not been found to be effective in reducing vehicular speeds (152, 204, 325). W. S. Quimby in a study of traffic patterns at a narrow bridge stated that (285): "...the type of warning sign had little effect in controlling the basic desire of the driver to maintain a constant speed. Rather, it would seem that the bridge itself performs the function of the warning sign in that the attention of the driver is focused on the entrance and not on the warning message of the particular slgn series." F. D. Maller in a study of school crossing protection reported that none of the fourteen sign conditions tested had a great deal of effect on vehicle speeds. He further stated (218): "...the 85th percentile speed w1thout any school crossing sign of any kind decressed two to three mph when children were present 
from that when children were not present. Certain sign combinations decreased the speed an additional three to five mph. However, the 85 th percent1le speed when children were not present for certain sign conditions was up to four mph higher than when no signs exdsted."

At an Intersection of a minor road with a major highway, a greater reduction in approach speeds on the minor road was observed to be produced by a "stop" sign than by elther a "slow" sign or no sign. As traffic volumes Increased on the major highway the decrease in approach speed on the minor road became more pronounced (325). H. O. Price reported that a "speed zone ahead" sign had no effect on the speed of the traffic at the location studied (278).

A study was conducted in Oregon in 1955 to determine the effect of a slgn "no traveling on paved shoulders" on average speeds both with and without edgestripes. The sign caused no apparent alterations in speed either with or without the edgestrips $(375,376)$. R. A. Moyer and D. S. Berry sumarlzed before-and-after studles reported by several states to determine the effect of "safe speed" signs on curves. They reported (238): "...speeds were more nearly uniform on marked curves than on unmarked curves and that there was less congestion of traffic on these curves. The greatest advantage to the motorlst provlded by speed signs is that they eliminate the surprise element when coming into a low speed curve, espec1ally on 1solated curves, where the approach speed may be 50 to $60 \mathrm{mph}$ and the safe speed on the curve 30 to $35 \mathrm{mph}$. Other studies have reported similar results $(418,434)$. Sign size and location on the roadway have been reported to have very little influence on speeds ( 173 , 204). 


\section{Pavement Markings}

Pavement markings are used in the fleld of traffic control to convey messages to the driver without diverting his attention from the roadway. The influence of two different types of "no-passing-zone" markings on vehfcle speeds was evaluated in 1949 by C. W. Prisk. One type, referred to as the Missour1 Zone, has the barrler line placed in the center of the lane from whtch passing is prohtbited. The other one, the national standard marking, places the barrier line parallel and close-to the roadway center-line markings. He reported the following (280): "Average operating speeds 500 feet in advance of the no-passing zones compared were almost Identical, and were slightly over $52 \mathrm{mlles}$ per hour for vehicles proceeding toward the zone. At a point 300 feet within each of the zones the general average speed level was lower by two to three mh, and the greater decreases occurred with forelgn drivers on the Missouri type marking and with Missourl drivers on the national otandard marking. The difference between the Missouri and the foreign drivers' reaction to the zone, measured in terms of that speed change, was larger at the Missouri zone, probably because Missourl drivers were better acquainted w1th the conventional barrier-Ine location than forelgn drivers were with the center-of-the-lane position used throughout Missour1." In a comparison of vehfcular speeds on two-lane pavements with and without "center-line markings it was reported that pavements with center-lines had higher speeds by approximately four miles per hour (382).

On two-lane, rural highways studied in Oregon in 1955, "pavement-edge" markings near the outside edge of fully paved shoulders was found to have no marked effect on speeds. However, when the "pavement-edge" markings 
were placed near the inside edge of partially-paved shoulders the average speed was reduced three mph $(375,376)$. After the installation of "pavement-edge" markings on rural highways in Connecticut, average speeds in the daytime and nighttime increased, respectively, 4.1 and $5.6 \mathrm{miles}$ per hour. In addition, the difference between day and night average speeds was reduced from 4.1 to $1.7 \mathrm{mph}$ after the delineation of pavement edges (442). Results of data recorded at six stations on a four-mile test section of the Merritt Parkway in 1953 showed a more unfform speed pattern, daylight speeds being reduced while nighttime speeds increased, after the test section was edgestriped (244). A study of the merits of painting speed-limtt numerals on the pavement at the beginning of speed zones showed no effect on spot-speed stat1st1cs (278).

\section{Speed Limits}

Speed control is probably one of the most important, difficult, and controversial problems of trafflc operations. No definite criteria for establishting speed zones has been accepted by all of the people involved. Speed control is important because it fac1litates movement at uniform speeds which is desirable from the safety and capacity standpoint; it is difficult because varlations in individual drlving behavior complicates the establishment of adequate, reasonable, and uniform warrants based on . objective speed surreys; and, it is controversial because of divergences of opinion among englneers, enforcement officers, the motorists, and the people living along the roadway as to approprlate methods of controlling speeds $(17,26,410)$.

The early speed laws generally stated that "speed should be reasonable and prudent for the conditions prevalent." The determination of a 
"reasonable and prudent" speed was generally left to the enforcing officers and the drivers. By the late 1920 's three kinds of speed limits had materialized: no speed Iimtt, 1.e., speed should be reasonable and prudent, prima facie speed 11mit, and absolute speed lintt $(68,137,141)$. Arguments for and against the respective speed limits fllled magazines and newspapers throughout the nation during the 1930's $(90,155,199,202,225$, 291, 387). Accordingly, speed laws were changed in various states as one system would be abolished and another adopted. The general trend, however, has been toward absolute speed limits, particularly within the cities, because such 11mts are generally essier to enforce $(100,207,287,330$, $331,350)$.

The literature contains several articles concerning the effects of changlng from one type of speed limit to another. These studies tend to indicate a slight increase in mean speeds, and a slight decrease in standard deviations when going from a "prima facie" limit to an "absolute" limit $(14,51,146,323,349)$. Other studies have compared speeds in adjoining states with different speed limit laws. These studies tend to indicate that the state laws have no apparent influence on the speed of motor veht$\operatorname{cles}(266,323,387)$

The results of many studies of the influence of speed regulations on vehtcle speeds are found in the literature. There is some disagrement among the findings of various investigators. Speed zones in urban areas seem to have very little effect on the drivers choice of speed. From a study conducted in Champaign, Illinols on major streets varylng from no posted limts through posted limits of $20,25,30,35$, and $40 \mathrm{mph}, \mathrm{C}$. C. Wley, C. A. Matyas and J. C. Henberger concluded that (435): "I) Traffic 
consistently ignores posted speed limits and even the absence of speed limit signs, and runs at speeds which the drivers consider reasonable, convenient, and safe under existing conditions; 2) Drivers do not operate by the speedometer but by the conditions they meet; 3) The general public gives little attention to what speed limits are posted." Similar results were observed in Nashville, Tennessee, by T. B. Deen (64), and in several Indiana cities by C. M. Elmberg and H. L. Michael (81, 83, 84). Other publications from various parts of the country have indicated the same conclusion that speedlimit signs in urban areas have little effect on vehicle speeds $(25,30$, $78,158,203,242,265,326,354,399,414,420,432,446,447)$.

Several speed studies, however, have indicated that average speeds are reduced when reasonable speed limits are posted on urban streets which were not previously zoned $(29,48,102,292,450)$. However, the raising of speed limits on urban roadways apparently has no significant influence on average vehicle speeds $(29,53,102,156,432)$. E. V. Avery studied in 1960 the effect of raising speed Iimits on urban arterial streets (11, 12). He reported that: "...the tendency is for any speed changes to be small and to bear no relationship to the change in the Iimit. There appears to be little or no relation between the amount of the limit raise and any change in actual speeds." Also, the lowerling of speed limits in urban areas of St. Paul, Mnnesota had little effect on vehicle speeds. A tendency was noted for the mean and 85 th percentile speeds to increase slightly (432).

The controlling effect of speed limits on the speed-volume relationship has been described by $0 . K$. Normann. At very low traffic volumes average speeds tend to be governed by speed Iimits, but as volumes increase 
average speeds tend to decrease in a linear manner with a slope somewhat less than that of the normal speed-volume relation. At some traffic volune depending on the actual speed limit, the speed-limit line will intersect the speed-volume line. At volumes bejond this point of intersection, average speeds are influenced by traffic volumes rather than by speed limits $(251,257,259,312)$. E. Goltz stated that (107): "...on the basis of mathematical considerations, it is concluded that a speed limit reduces the capacity of a road and the lower the speed limit, the more the capacity 1 s reduced."

There are also some conflicting reports as to the effect of speed zoning in rural areas. From studles conducted in Wlsconsin (223), H. W. Mohr concluded: "... when speed linits on maral highways are reasonably lowered through properly applied speed zoning, there is generally a substantial reduction in the average and 85 th percentile speeds of all motor vehicles." These same results have been reported in other investigations of speed zoning in rural and Intermediate areas $(49,98,142,154,217$, $255,308,372,403)$. Other traffic speed reports have concluded that the erection of speed linits on rural highways produce no significant changes In the speed characterist1cs $(8,52,53,62,71,76,80,138,156,164$, 187, 212, 216, 229, 262, 269, 444). From data collected in a comprehensive survey of traffic speeds on Illinols highways where exdating speed limits were raised, no changes were apparent in the speed characterist1cs. However, reductions in speeds were observed where new speed zones were establ1shed and where exdsting speed 1 imits were lowered $(168,169,283)$. R. J. Smeed sumarlzed data (327) from speed studies made in Belgium, Holland, the U. S. A., New Zealand, Northern Ireland, and Great Britain. 
He concluded that: "In nearly all cases for which we have satisfactory data, a speed linat had a marked effect in reducing the higher speeds. In other cases, the distribution of the speeds was identical before and after the imposition of the limtt. This may have been because of the signs indlcating the speed limfts or, in some cases, of the measurements of speed. In a few cases, it may have been due to the unsatisfactory nature of the speed IImit."

Mang studies have indicated that speed limits are desirable and can be effective if they are based on sound engineering studies $(38,63,207$, $328,332,340)$. Properly established speed zones assist the motorist in selecting speeds that are safe and that permit him to obtain the maximum utility, economy, and convenience from his vehicle and the road. In general, It appears that drivers tend to observe speed limits that are reasonable, proper, and safe for existing travel conditions and disregard speed Iimits that appear to be unreasonably high or low.

In recent years there have been several articles written concerning minimum-speed laws. As early as 1927, A. J. Brosseau wrote (32): TWe now think of our highway traffic in terms of maxdmum speed limits. Equally important, I believe, is the consideration of minimum speed limits. It is essential that the point of madmum volume be discovered and studies made with a velw to moving traffic at a speed that will produce the highest posstble average rate of traffic plow. To this a minimum speed limit will be as necessary as maximum speed limits and enforcement equally as vital." Other reports have pointed up the need for minimum speed laws, most of them on the basis of eliminating driving hazards (107, 303, 309, 393). Minimum speed laws are becoming almost untversal on freeways. The 
results of studies of the effect of minimum limits have been very favorable $(205,220,393)$.

The benefits occurring from the erection of properly-determined and properly-posted speed limits can be sumarized as permitting the concentration of enforcement on voilators of safety, reducing maximum speeds, decreasing the range in speeds and the number of passing maneuvers, and informing people of the actual speeds being traveled within the speedzoned area (53). 


\section{ROADSIDE DEVELOPMENT}

There is very little information in the literature concerning the effect of roadside development on vehicle speeds. A research profect was conducted in North Carolina in 1960 to evaluate quantitatively the effect of comercial roadside development on traffic operations. Speed data were collected by the moving vehicle technique. The average speed of the traffic stream was functionally related to traffic volume by the equations: $Y=44.67-0.02 X$ for developed sections and $Y=47.67-0.02 X$ for undeveloped sections, where $Y$ is the average speed in miles per hour, and $X$ is the traffic volume in vehlcles per 15 minutes. The reduction in speed caused by roadside development was reported to be constant and independent of traffic volume $(147,148)$.

An intensive study of factors influencing traffic speeds was conducted in Texas by N. J. Rowan and C. J. Keese in 1961 (302). They reported that concentrated comercial development apparently has a substantial influence on speed. In one case, speeds were observed to increase as trafflc passed from a comercial area into a predominately residential area of equal or greater density. "However, it is recognized that restricted sight distance in the commercial area wes also a contributing factor. The second occurrence of concentrated commercial development in the study also caused a marked reduction in speeds. In this case there were no additional factors involved." Residential development was observed to decrease speeds to a lesser degree than did commerclal development. "The appearance of residential 
development determined too a great extent its level of influence on traffic speeds. Residential areas having good lateral clearance had far less inIluence on speeds than those where shrubbery and trees were planted near the curbline." They further stated: "The density of residential development expressed as a percent of occupancy did not appear to correlate with speeds, except in 1ts extreme ranges. It was noted that areas of residential development having the same density had entirely different appearances to the driver; and, as pointed out previously, the appearance of development seemed to have a great influence on the driver's selection of speed." A study $(81,83,84)$ conducted in ive Indiana cities reported that, "Although the study did not produce conclusive results, the many significant differences noted in the speeds indicated a strong possibility that there is a significant eflect on speed by type of development." 
OTHER CHARACTERISTICS

This section will cover those characterlstics which did not logically fit under any of the previous headings.

\section{Driver}

There are several driver characteristics which have been studied that have not been mentioned previously. One of these 1 s attention of the motorist. Apparently the individual can focus his attention on only one thing at a time; however, he can oscillate his attention very rapidly between several different stimuli (126). Thus, drivers traveling in heavy traffic tend to realize that they are unable to observe all the events occurring around them and, as a result some will slow down, others will change position, and still other $\mathrm{w}$ wll trust that others can observe their actions and will compensate for their mistakes $(85,400)$.

Another variable that has often been consldered in analyzing speed characteristics is the driver's sex. Several reports have concluded that women drivers travel at about the same or at a slightly lower average speed than men $(65,135,142,355)$. In a study (175) of vehtcular speeds on two-lane, rural highways conducted in 1940, C. H. Lawshe, Jr. reported: "...of the 608 speed records that were obtained, 505 of the drivers were men and 103 were women. These men had a mean speed of $45.5 \mathrm{mph} \pm 0.40$ as compared to a mean of $42.5 \mathrm{mph} \pm 0.77$ for the women. Th1s difference of three mp is statistically significant since the critical ratio is $3.45 . "$ 
He further concluded that women farther than 25 miles from home did not differ from men in their speed practices. Studies of vehicle speeds on rural highways in Connecticut (396) and Rhode Island (333) in 1936 and 1937 indicated that there was no signiticant difference in the speeds driven by men and women. However, a more recent study conducted in Connecticut (7I) and a study conducted by W. J. Toth in the northeastern states (399) showed the females to be driving faster than the males. W. J. Toth also reported (399) that: "One test made in a New England state revealed that 53 percent of all the speeders warned were women..." It has also been reported that divorced men and women and single women drive faster than married men and women (252). A. R. Lauer reports that: "The driver habits and exposure risks of men and women drivers are so vastly different that no fair direct comparison can be made between them..." (172).

Drivers age has also been considered in the evaluation of factors influencing vehicular speeds. A study of driver characteristics (252) in Californta reported the following: "...the men, those in the age group from 25 to 30 , traveled at the highest average speed in the daytine and also at night. A higher percentage of this group than of any other group exceeded the speed lint.

"Speeds of drivers younger than 25 decreased with a decrease in age and speeds of drivers older than 30 decreased with an increase in age, with the exception that at night men over 60 traveled at approximately the same speed as the average driver. Most drivers traveled more slowly at night than in the dayt1me. The men over 60 traveled faster at night than in the dayt $1 \mathrm{me}$. 
"The youngest group of women drove faster in the daytime than any other age group but not appreciably faster than the women between the ages of 20 and 30. Fourteen percent of the women under 25 years of age exceeded the speed limit in the daytime. All women speeding at night were between 40 and 50 years old."

As a rule, persons below the age of 40-49 years drive somewhat faster than those over this age group $(17,65,66,135,142,178)$. However, other studies have reported that the blame for speeding cannot be attributed to any particular age group $(354,355)$. C. H. Lawshe, Jr. reported (175) that: "Drivers between the ages of 40 and 49 drove faster than any other group and faster than all other groups combined. "...drivers in the younger age brackets drove no faster than did drivers in the older group." Youthful male drivers, as observod in Iowa, travel too fast at late hours of the night for their experience and the lighting conditions (172).

There is little consistency in the literature concerning the effect of drivers age on vehicle speeds. It is thought that there are other physical and psychologlcal factors which tend to cause this inconsistency. The difference in average speeds between age groups is certainly not large.

Several reparts have indicated that lone drivers tend to drive faster than drivers with passengers $(65,66,71,142,175,333,396)$. A study (65) made in Connecticut reported that: "Lone drivers and drivers with passengers to whom they were not related drove faster than drivers with passengers related to them." $0 . K$. Normann in a study conducted in California found that men traveled at approximately the same speed with or without passengers while lone women traveled two mph faster than the average woman driver and women with five or more passengers had average speeds $4.6 \mathrm{mph}$ 
slower than the average speed of all women (252). One study reported that Negro motorists in South Carolina traveled faster with passengers than when alone $(66,67)$.

It has generally been concluded that non-owners drive faster than those who own the vehicle which they are operating (142). This is particularly true of younger drivers (65). O. K. Normann reported that men owning the vehicles that they were driving usually traveled slower than men not owning the vehicles they were driving, while with women just the opposite was true (252).

Only two publications were found which considered the influence of driver occupation on speed characteristics. The 1939 Connecticut study (65) Indicated that: "...chauffeurs were the fastest drivers and truck drivers in private cars were the slowest. The speed of salesmen was about the same as the speed of the average driver. ...the various occupational groups among women drivers had no marked differences in average speeds." 0 . K. Normann in his study (252) of driver characteristics reported that: "The highest speed men drivers were salesmen and those engaged in the professions. These two groups traveled about 2.5 miles per hour faster in the daytime and 3.5 miles per hour faster at night than the average drivers. They were on longer trips and drove newer cars than the average driver, factors which themselves are characteristics of high speeds. Of the women traveling during the day, the average speed for the students was higher than for any other group or 2.3 miles per hour above that of the average women. .... at night, business women were the highest speed drivers, traveling 2.5 miles per hour faster than the highest speed group of men drivers and 5.9 miles per 
hour faster than the average woman. .... It is significant that neither the high speed women drivers in the daytime nor the high speed women drivers at nlght were on as long trips as the average woman driver."

Both men and women drivers traveled at approximately the same average speed whether the trip purpose was business or pleasure (65). However, a larger percentage of drivers on business trips exceeded the speed limit (252).

The literature generally indicates that the length of driving experlence for men has no effect on vehicular speed, while the average speed of women drivers increases as the number of years of driving experience increases $(65,66,252)$. Another driver variable closely related to driving experience is annuil travel. On the average, drivers with higher annual mileages operate their vehicles at higher speeds than those with lower annual mileages. The influence of annual travel on spot speed statistics is more pronounced for women and for men in daytime travel than for men traveling at night $(178,252)$.

Another factor which was included in two reports is driver attitude. L. G. Goldstein and J. N. Mosel observed that women drivers apparently have good attitudes toward speed and violate few speed laws. No significant correlation was obtained between men's attitudes and any of the variables measured (106). C. H. Lawshe, Jr. concluded that 21 percent of the variation in driving speed can be attributed to the variation in drivers' attitudes (175).

E. L. Allgaier did an extensive study of the influence of several miscellaneous driver variables on speed in 1938 (6). The following is a brief sumary of his results: 
1. As driver reaction time increased from 0.29 to 0.66 seconds, the actual speed of travel increased from 46.0 to $47.2 \mathrm{mph}$. Above 0.66 seconds the speed of the drivers decreased with an increase in reaction time.

2. Persons scoring high on the muscular coordination test drove 4.4 mph faster than those persons with low scores.

3. Drivers with good vision drove faster than those with poor vision.

4. Both those persons with good distance judgment and those with poor distance judgment had average speeds of $46.4 \mathrm{mph}$, while those persons with average distance judgment had an average speed of $47.5 \mathrm{mph}$.

5. Persons with normal or low blood pressure drove faster than those with high blood pressure.

6. No definite relationship was observed between speed and driver excitability.

7. There was a slight tendency for drivers with better steering ability to drive somewhat faster.

B. D. Greenshields reported that driver reaction time decreased from 0.539 seconds under $30 \mathrm{mph}$ to 0.507 seconds at $60 \mathrm{mph}$ (110).

\section{Vehicle}

Vehicle characteristics which have been studied and have not been previously discussed include age, weight, and horsepower.

A number of authors have evaluated the effect of vehicle age on speed characteristics, and have concluded that newer cars are driven faster than 
older ones $(17,65,66,67,135,142,178,186)$. 0. K. Normann concluded (252) that: "...for a given travel distance, the average vehicle speed decreases as the vehicle age increases, the rate being slightly greater for the older vehicles." This relationshlp between speed and vehicle age was also reported by C. H. Lawshe, Jr. (175). The reasons given for this relationship are that new cars are more comfortable, run smoother, quieter and faster, handle better, and in most cases are in better mechanical condition $(65,67)$. A. R. Lauer did not find this same relationship in his study of driver characterlstics in Iowa. He reported that older cars are driven faster in the country than new cars throughout all hours of the day (172).

The weight of vehicles, both passenger and commercial, have been correlated with speeds. On the average, heavier passenger cars are driven faster than lighter ones $(175,186)$. From the 1961 truck-weight-speed study on Indiana highways (388), K. J. Tharp reported that: "For singleunft trucks on both two-and four-lane highways, the speeds vary somewhat with the vehicle welght. Mult1-unit vehicles indicated no evidence of a relationship between truck weight and truck speed." The average road speeds of gasoline-powered comercial trucks in the lowest range of engine slze and power in freight service on rural highways were observed to decrease sharply as the gross welght increased. This decrease in speed was less pronounced as the engine horsepower and gross vehicle weight increased. These conclusions were developed by the Bureau of Public Roads from data collected in 1957-1958 on travel characteristics of trucks operating in free-flowing traffic on rural, line-haul service (166, 167). 
Both the average speed of travel and the horsepower of the automobile have been increasing over the years, but since World War II horsepower has increased much more rapidly than average speeds $(367,368)$. R. E. Schmidt determined in 1953 (311) that: "The highest powered vehicles, while driven more frequently in the high speed ranges, are not driven at any greater axdmo speeds than the lower-powered cars, except perhaps for those under 100 horsepower.

"As the percentage of high-powered vehicles on the highway increases, the average speed of traffic may be alightly increased.

"The vehicles with from 100 to 130 horsepower appear to be driven as fast as and rehicles of and horsepower.

"Inasmuch as vehicles of 100 to 130 horsepower are generally capable of maxdmum speeds in the range of 85 to 100 miles per hour, it would appear that the critical factor in determining highway opeeds is still the driver and not the vehicle."

Over the years several people have proposed putting governors on all automoblles as a means of cutting down on excessive speed and increasing safety (179). Most traplic engineers havo opposed this idea (268). M. McClintock stated (200): "Perhaps the chlef argment against the governor lles in the fact that it can do no more than control the maxdmum speed, and that frequently the most hazardous speed is one much less than that set by the law." From a study of the effect of governors on passenger car performance in 1955 (366). K. A. Stonex reported that: "The data presented indicate definitely that a governor can be detrimental to acceleration and performance. It is just as reasonable to contemplate putting a governing device on the brake system to IImit deceleration and 
Increase stopping distance as it is to install one which limits acceleration and increases passing distance."

\section{Speed Advert 1sements}

For several decades many persons have been quite concerned ebout automobile sdvertising of the "high speed vehicle". They claimed that this would have a psychologlcal effect on drivers and increase their destre for speed $(7,46,89,364)$. No information was found in the literature of any studies to determine what effect, if anj, such advertising has actually had on vehicle speeds.

\section{Pneumatic Road Tubes}

A study was conducted in 1959 to determine the effect of pneumatic road tubes on vehicle speeds (59). This study revealed that the presence of pneumatic road tubes on the pavement produced a significant bias in measured speeds as opposed to actual speeds. The measured value was consistently lower than the real speeds, with the error becoming more pronounced with higher speeds. Tube color, spacing and legal speed limits were also observed to affect the magnitude of error. It was concluded that: "The error in measured speeds is not systematic for any tube-highway configuration and cannot be compensated for by means of a correction constant." Thls was the only study of this nature found in the literature. 
SPEED AND ACCDDENTS

The literature ts full of articles concerning speod and accidents. There have even been several books written in which at least one entire chapter is devoted to the subject of speed and accidents $(50,67,124$, 126, 160, 304, 343). Therefore, no attempt w1ll be made in the short space available to sumarlze all of the articles written on the subject. Rather, the basic 1deas, and the referencespertalning to each will be introduced.

There are many articles in the Iiterature which proclaim that "speed" is the most important factor in traffic accidents. These reports present "statistics" and "1deas" to support their claim (17, 19, 23, 27, 33, 34, $40,41,42,47,57,65,79,86,87,90,101,129,171,176,224,239,248$, $268,272,274,282,318,328,347,351,360,392,394,396,409,428,433$, 441, 453). Many other reports claim that the number of accidents due to excessive speed is greatly exaggerated, and that it is really an important factor in comparatively few cases. They too present "data" and "1deas" to support their claim $(10,60,128,149,180,184,249,263,266,323$, $335,342,345,362,363,398,443,445,452)$.

One report which presents the 1deas of four different men represents both sides of the controversy (63). The literature also contains information to show that slow speeds figure in accidents almost as frequently as do high speeds, and are as often to blame $(55,134,339)$. However, one article (56) reports that: "The driver who blames the slow-poke driver 
for any significant share of our traficic death toll is looking for a scapegoat and is trying to salve his ow conscience for his driving behavior." Several authors have maintained that the reason for this disagreement is the scarcity of reliable accident records $(125,165,216,227,230,237$, 420). A. H. Rowan suggested (301) that: "Speed alone does not kill until a driver allows it to become greater than his ability to control it."

J. E. Johnston reported (158) that: "One of the best attempts to establish some relationship between speed and traffic accidents was the study conducted by the New York State Department of Public Works In 1954. ...The important Pinding was that there were no speed intervals throughout the speed range in which accident drivers were more dominant." He further stated that: "If the results of the New York Study were given the same weight that is given most traffic accident atistics, the following conclusions would have been reached: Speed limits should be lower in the afternoon than in the morning; only drivers over 59 years of age should be permitted to driver; when a driver has driven 5,000 miles during any one year he should have his driving privllege revoked for the rest of the year; slower drlvers must speed up during the afternoon on tangents; no automobile should be perwitted on the road until it is at least three years old; and of course, vehtcles should be permitted on the highways only whenthe highways are wet, snowy or icy and they should NOT be permitted when they are dry or the condition is unknown. The above are not listed for the sake of being facetious, it is to dramatize how far afleld we have wondered in some of our conclusions about traffic accidents, especially as they are related to speed." 
M. Halsey, in 1940-1941 offered the following examples of "erroneous premature conclusions" which the people accepted in the face of a rapidly increasing death rate $(123,124)$ :

"I. Speed is the cause of all accidents.

2. Manufacturing of slow cars or placing governors on all cars would stop all accidents.

3. The answer to the accident problem is to take the fools off the highway.

4. If motor vehtcle drivers were trained as thoroughly as railway engineers, there would be no accidents.

5. All you have to do to stop accidents is to arrest more people.

6. Accidents are a very real problem and must be stopped by a carefully prepared attack aimed solely at accidents.

7. Lack of courtesy on the highway causes all accidents."

He further stated that: "The above panaceas, which have been heard far too frequently in the past, are to the traffic fleld what pitent medicines and quackery are to the medical field. They deal primarily with surface indications and contribute nothing to uncovering the fundamental causes of the difficulty. They have served to set 'accidents' upon a pedestal as an independent problem. This has acted as a red herring which has, unfortunately, drawn Inveatigators off the trail of the real problem."

There is a great deal of controversy concerning the influence of state-wide speed limits and speed zoning on vehicle accidents. Reports have shown that those states with speed limits of $50 \mathrm{mph}$ or less have fewer traffic deaths than the national average $(170,401)$. Others have reported that accidents involving death or serious infury are more frequent 
on roads without a speed limit as opposed to those with a $30 \mathrm{mph}$ speed limit (102). A report from Germany stated that after the abolition of speed limits, accident erequency decreased, but the death and casualty rate increased. Some studies have reported that establishing or lowering speed Iimits reduces accidents (168, 187, 283, 327). However, some of these have indicated a reduced number of accidents but no reduction in speed where speed limits were established (187, 283). In a study conducted on the Pennsylvania Rurnpike it was reported that the majority of the fatalities occur on the lower speed limit sections (184, 269). Other studies have shown that by raising the speed limit accidents were decreased $(168,308,403)$.

D. S. Berry reported (25) that: "Attempts to correlate rural speed limits and accident records of states have been made but results seem to have no slgnificance because of the many other factors which may contribute to differences in the accident rates of different states." He further reported that: "A special study of the case histories of 892 fatal highway accidents occurring during 1936 showed that the violution 'excessive speed for the conditions' was reported for 636 of the drivers Involved in these accidents. It was concluded that relatively few accidents can be fairly charged to any one violation or condition, and that most accidents generally result from multiple contributing circunstances, an average of nearly three important factors having been found to contribute towards each accident." Other reports have confirmed that most accidents are the results of more than one contributing factor (213, 214 , $240,424)$. 
It is generally agreed that severity of resulting injury or damige In accidents invreases with increasing $\operatorname{speed}(25,127,203,213,214,215$, 240). D. S. Berry reported (25) that for every 1000 drivers involved in infury accidents: at $20 \mathrm{mph}$ or less, 19 were involved in a fatal accident; at 41 to $50 \mathrm{mph}, 61$ were involved in al fatal accident; at speeds above $60 \mathrm{mph}, 160$ were involved in ratal accidents. Thus, the "severity ratio" is over eight times as great at speeds over $60 \mathrm{mph}$ as it is for speeds at 20 mph or less. " study by J. 0. Mo re (226) reported thit: "...traveling above $59 \mathrm{mph}$ more than doubles the risk of dangerous or fatal injury." He further concluded that: "Control of excessive speed without simultaneous control of car design imposes limitation on the extent of reduction of dangerous or fatal injuries in injury-producing automobile accidents."

It has been stated that high speed is a very important cause of acc1dents at night in sections where visibility is limited to the range of the headlights. The visibility is even further restricted by the glare of oncoming headlights $(243,324)$. One article has presented the maximum possible safe speeds for a given candle power and color of objects (105). One author especially blames speeds too fast for the sight distance provided by hendlights for rear-end collisions (358).

in accident investigation conducted during the first six months of 1950 in lexas (5) showed that 30 percent of the drivers involved in rural fatal traffic accidents had been drinking. It was further stated that: "Drinking drivers either drive faster than non-drinking drivers, or they are more prone to vollate other traffic laws while speeding." Two studies were conducted recently to determine the effect of low levels of blood alcohol on driving ability. The results of one study with a blood alcohol 
level of approximately 0.05 percent suggests that driving impairment is produced in some people at this low level $(94)$. The other study $(144)$ was conducted with 0.01 percent blood alcohol. The six drivers participating in this study stated that: "...they felt in their own opinions that their driving abilities were definitely impaired to such degree that they would not ordinarily attempt to operate a motor vehicle in that condition." As a result of the physical examination, one driver was graded as "apparently no alcohol effects," two were graded "slightly" and the remaining three were graded "obviously under the influence".

Saf'ety campaigns have proved very effective in reducing accidents for a short period of time. However, no reports have indicated what happens after a year or so. Some reports have indicated that by strict enforcement of speed limits in urban areas nd the aid of "safety campaigns" accident rates have been reduced up to 17 percent $(14 \mathrm{C}, 292,296,315,316$, 317). Kinsas City, in a safety campaign in 1939, reduced their night speed limit to $25 \mathrm{mph}$ with an allowable maxmum of $35 \mathrm{mph}$ on through streets. A 68 percent reduction in night fatal accidents was reported for the city in 1939 as compared to $1938(315,316,317)$. No checks were made to determine what effect this had on average speeds. In a safety campaign in Connecticut they suspended the license of every convicted speeder for a minimum of 30 days. After six months fatalities had decreased nearly 15 percent (296).

Several reports have indicated that the use of speed metering devices have reduced accidents $(139,277,341)$. With regard to. this, J. Darrell said (63): n...frenkly, I get a chuckle out of the idea of going out with radar to prevent accidents. I can drive down the street and see a lot 
more accident causing violations than just speed in any one mile of driving."

C. Adler, Jr. has suggested the use of a "block system" as a safety measure for the highway syatem (4). He said: "Why not protect each motor vehicle with a block system? It could be done in a simple and inexpensive manner - merely by painting across the right lane of the highway, transverse lines, sp ced braking distance apart for the particular speed zone in which they are located."

k. A. Stonex summed up the accident situation like this (368): "A review of accident fatalities shows that there has been a consistent reduction in the mileage rate of fatal accidents; what is seldom emphasized is the more-important fact that the total number of fatalities has leveled off and remained nearly constant during the past 20 years in spite of the tremendous increase in tot? miles traveled."

The following quotation from "Automobile Facts and Figures", shows that some progress is being made so far as traffic deaths are concerned (10): "The nationil traffic death rate in 1961 reached an all-time low of 5.2 deaths per 100 million miles of travel, compared with 5.3 in 1960 . It was the sixth straight year of decline in the rate, which now is but one-third the 1927 level." This also tends to disprove the idea that accidents increase with increasing speed, since the average speed for 1961 is approximately twice that of 1927.

Essentially, there are two main schools of thought concerning speed and accidents, and it depends on which "school" you are associated with as to your interpretation of the statistics (219). The following illusstration should serve to point out this idea: 
Mo McClintock in his discussion in 1937 (198) stated: "There are two methods of approaching an analysis of speed in its relation to the accident problem. One approach may be called the 'sentimental'. This approach envisions accidents as caused by reckless, foolhardy, anti-social or intoxicated drivers, who race over our streets and highways at very high rates of speed, whth utter disregard for public safety, until they k1ll or are killed.

"The other approach to the speed problem may be called the 'realist1c' one. It recognizes that all traffic accidents could be eliminated imediately if zero speeds were universally in force. It recognizes, however, that, important as are life and limb, complete protection in this form would be bought at too high a price.

"The realist does not visualize the traffic accident problem as resulting from the super-speed of a few abnormals, but, rather from the daily operation of $28,000,000$ motor vehicles by 40,000,000 reasonably average, normal, Individual citizens who become involved in accldents because a vehicle or vehicles, under a particular set of circumstances, are traveling at 'excessive speeds'. This range of excessive speed may be from practically zero miles per hour to 100 miles per hour.

"These accidents are caused not by speed per se, but by speed which is excessive for the particular condition. These conditions may arise from unfavorable factors in the driver, in the vehicle, or in the roadway or its traffic. A speed of $25 \mathrm{mph}$ may be excessive and fatal under a particular set of circumstances whereas a speed of 55 or $60 \mathrm{mph}$, under favorable circumstances, may, by no means, be excessive nor have any substantial degree of hazard involved. It is not, therefore, speed alone 
which causes accidents but speed which is excessive for conditions."

The Association of Casualty and Surety Companies reported as follows (334): "There are two general viewpoints as to what speed is safe under what conditions -- for the purpose of this discussion, let's label them as 'conservatives' and 'liberals'. The numerous proponents of 'liberalism' regarding speed will usually agree with the 'conservatives', for example, that on icy roads everyone should drive slowly for safety's sake....

"However, these liberal thinkers on speed also feel that on a dry straight road -- or, as they explain it, 'under ideal conditions' -speeds well above $60 \mathrm{mph}$ are safe and should, therefore, be allowed. They mintin furthermore that speed is not serious as a fiactor in accidents and should not therefore be considered worthy of so much emphasis by police, or by 'eafety groups'.

"They argue -- rightly or wrongly -- that to move the traffic volumes we are faced with, we must have speed, high speed ..... or perhaps, more prec1sely, higher speed. They believe furthermore that the public should be 'allowed to set the speed limit,' based strictly on observations of the statistical 85-percentile speed of traffic.

"The 'conservatives' are at variance with some of these precepts. First of 2ll, they malntain that exceeding speed limits and/or speeds safe for existing conditions is a very major cause of accidents. They believe also that the average driver cannot reliably control excessive speeds regardless of 'Ideal conditions'. There is a recognition that the 85-percentile speed may be the most practical basis for setting many speed limits, although if accident experience shows that fast driving is a major contributing factor, there may be some merit in restricting operating speed bolow the apparent 85 -percentile demand point." 
Although the literature contains many articles which discuss speed as a factor in accidents, as presented above, only one article was found which mentions the influence of accidents on vehicular speeds. Although no study was made, it was suggested that reductions in traffic speeds depend mostly on the severity of the accident, the traffic volume in relation to the capacity of the facility at the time the accident occurs, and the time required to remove any disabled vehicles which might have remained on the travelway. A rither serious accident on an uncongested facillty may cause only a minor reduction in speed, while the mere presence of a stalled vehicle on a roadway operating near capacity may cause complete stoppage of traffic (423). 


\section{SUMMARY}

The summary of the literature reviewed is presented under the same topic and sub-topic headings as used in the test of the report.

\section{Speed Trends}

All States reporting speed trend data have shown a gradual increase in vehicle speed since the war time low in 194a. The average increase per year since 1942 has been approximately one mph per year, with the rate of increase being greater right after world har II (approximately two moh per year for five years), and less in recent years (approximately one-half mph per year for the past ten years).

The average speeds of vehicles in the central and western regions of the United States have been consistently higher than those in the eastern region. Also, some variation in average speeds have been noted for different areas within a single region.

\section{Road Geometry}

In general, speeds of all vehicles are higher on a higher type facility than on a lower type, and average vehicle speeds on the same type of facility are higher in rural areas than in urban locations. .

\section{Horizontal Curvature}

Numerous investigations of traffic stream characteristics have resulted in the conclusion that vehicle speeds on horizontal curves are lower than 
those on tangent sections, and that the average spot speed approaches the design speed of the curve as the degree of curvature increases. The average speed on curves designed for high speeds approaches the average speed on adjacent tangent sections.

For free-moving vehicles, adjustment in speed because of curvature or limited sight distance is made on the approach to the curve. Once the vehicle has entered the curve there is little change in speed until it leaves the curve. Curvature has a greater effect on vehicle speed than does sight distance.

\section{Vert1cal Alinement}

The vertical alinement of a roadway has a pronounced effect on vehicular speeds. Passenger-car speeds are little affected by grades up to six or seven percent, but truck speeds are reduced by much flatter grades with the effect increasing as the grades become longer. The most Important factors affecting the speeds of comercial vehicles on up-grades are gradient, length of grade, gross vehicle welght, approach speed, and engine horsepower.

Average spot speeds on down grades as compared to speeds on adjacent level tangent roadways are higher for grades up to five percent for trucks and three percent for buses and passenger cars, but less for down grades in excess of these linits.

Grades acceptable where traffic volume is light and passing is not restricted are not satisfactory where high traffic volumes reduce passing opportunities.

Speeds at vertical curves, regardless of the sight distance, are primarily governed by the normal speeds on the highway preceding the curve. 
Passing Sight Distance

Restricted sight distance on two-lane highways limits the number of opportunities to pass and larger volumes of traffic reouire more opportunities. Therefore, the actual operating speed is determined by the combined influence of trafflc volume and the percentage of the total roidway length which has insufficient sight distance to permit passing maneuvers.

\section{Cross-Section Elements}

Number of lanes: It is generally agreed that average spot speeds on four-lane facillties are greater than on two-lane facilities, except for verp low trafic volumes. Spot speeds on divided multilane facilities are also usually slightly greater than on undivided multilane highways.

It is generally agreed that roadways with more than four-lanes have speed characteristics simflar to those for four-lane facilities.

Lane width: In general, for main two-lane rural highways it can be concluded that very slight increases in speed with increased pavement width will probably occur.

Lane position: On horizontal curves, on two-lane rural highways the average speed on the inside lane is about the same as that on the outside lane.

On three-lane highways the two outside lanes show the normal linear decrease in average speed with increase in traffic volume, but the center lane has a higher average speed than the outslde lanes, and the speed does not appear to change with variations in traflic volume. 
On multi-lane facilities the slowest average speed occurs in the right lane and the highest in the median lane.

Road surface type: Speeds tend to increase as the type of road surface progresses from low to high. Different road surfaces of a comparable type, such as bituminous concrete and portland cement concrete, have similar speed characteristics.

Medians: Average speeds are higher on divided than on undivided mult1lane facllities. The placing of a median on a multilane facility whout providing additional width will probably result in decreased average speeds.

Curbs: Mountable curbs do not materially reduce average speeds, but barrier curbs tend to reduce average speeds by two to three mph unless additional lane width is provided to compensate for these curbs.

Shoulders: Veh1cular speeds are not materially affected by the width of shoulder, providing the shoulder is more than 4-ft wide. Well-maintalned grass shoulders have the same effect on vehicle speeds as do well-maintained gravel shoulders.

Lateral clearance: In general, travel characteristic studies have indicated a reduction in vehicular speeds when restricted lateral clearances were produced by placing objects on roadway shoulders. The reduction, however, rarely exceeds three mph, except for very narrow or long, high truss bridges.

Friction points: There is generally believed to be a tendency for speeds on roadways to decrease with an increase in the number of friction points encountered per untt of distance, but there is little factual evidence to support this belief. The presence of children at the edge 
of the roadway lowers the 85 th percent1le speed three to four mph.

Speed change lanes: In general traffic on properly designed acceleration or deceleration lanes has little effect on the speed of through traffic on multilane facilities.

\section{Trafic Stream Characteristics}

If a driver is to proceed at a desired speed he must have unlimited opportunities to overtake and pass on two or three-lane highways and on multilane roadways he nust be able to change lanes and pass.

$$
\text { Speed, Volume and Density }
$$

Both volume and density effect vehicle speeds. For volumes and densities up to, and well beyond, the practical capacity the speed-volume and speed-density curves closely approximate straight lines with speed decreasing as volumes and densities increase. In the area where volume approaches possible capacity the speed-volume and speed-density curves devlate considerably from straight lines. Several studies have found that speeds decrease by approximately one mph for each increase of 100 vehlcles per hour of volume.

\section{Longitudinal Distribution}

The location of a preceding vehicle in the traffic stream affects the following driver's speed if the distance between the two vehicles is less than some minimum distance and the following vehicle is not able to pass freely. The minimum distance maintained is proportional to the speed at which they are traveling. 


\section{Passing}

In order for the faster moving vehicles to maintain their desired speeds there must be adequate opportunities for them to change lanes and pass the slower moving vehicles. The average passing vehtcle travels about ten mph faster than the vehicle being passed and about six mph faster than the average speed of all traffic. Both the passing and passed vehlcles average their normal travel speed during the passing maneuver with the passing vehicle slowing to within about five mp of the vehfcle to be passed and accelerating to a maximum speed of three to four mph above 1ts normal speed.

\section{Traffic in the Opposing Direction}

There is some indication that opposing traffic has only a very small influence on vehfcular speeds; the influence 18 so small that for all pract1cal purposes it can be ignored.

\section{Driver Residence}

Trip distance is one of the most important factors affecting driving speeds. Drivers on short trips travel slower than those on long trips with the long-trip drivers traveling two to four mph faster than those on short trips. Drivers on multilane facilities, however, tend to travel at similar speeds irrespective of the length of the trip.

\section{Varlation with Time}

Varlations in vehtcular speeds have been analyzed according to the various time cycles of the jear (discussed previously under "Speed Trends"), season, month, day and hour. 
Seasonal

All vehicles tend to travel somewhat faster in the fall than in the spring and sumer. This difference appears to be about one to two mph.

\section{Monthly}

Only one study was found which considered the monthly variation in speeds. It reported that the difference between monthly mean speeds was larger than could be accounted for by chance.

\section{Daily}

Most of the reports agree that, in general, Sunday speeds are lower than those observed on other days. No apparent trends are reflected in the studies for the other days of the weok. It 1 s belleved that differences in trafflc stream characteristics rather than the day of week resulted in the speed variations reported.

\section{Hour of Day}

There 13 sufficlent information to suggest that a significant variation in vehtcular speeds occurs during the day. There are also indicatlons that at least some of the reported variations may have been due to stream characteristics which differed during the day rather than to the hour of the day.

\section{Day vs Night}

It appears that night speeds are slightly lower than das speeds, and that the decrease varies with the different types of roadway facilities. For most facilities the decrease is two mph or less.

Illumination and delineation: These aids to night visibility apparentIy have very little effect on the average speeds of vehicles. Several 
studies indlcate that average night time speeds may be increased by one to two mph by delineation.

\section{Weather Conditions}

In general, inclement weather tends to lower vehicle speeds, with the amount of reduction varyling with the severity of the conditions. The motoring public tends to adjust its speed to the individual driver's interpretation of the relative danger of road hazards encountered. Bad surface conditions (snow and ice) create greater speed reductions than do lower visibility conditions.

\section{Spead Control Measures. -}

Varlous types of traffic-control devices and techni gues are employed In an attempt to regulate the Plow of vehicles. Some of these have been favorably accepted by the general public while others have caused considerable discussion and disagreement.

\section{Controlled Access}

Access control results in a slight increase in average speeds in rural areas, and substantial increases in average speed in urban and suburban areas.

\section{Enforcement}

There is a tendency for traffic to slow down in the trmediate vicinity of any type of enforcement unit. For a moving patrol unit the slowing offect is limited to the vicinity of the unit, with this influence essentially dissipated within four wiles either side of the unit. 


\section{Traffic Signals}

Vehicular speeds apparently are influenced in varying degrees by the presence of traffic signals depending on the type of signal, the signal timing, and the frequency of signals. Average speeds tend to increase when a signal system timing is changed from simultaneous to progressive.

Flashing beacons do not appear to have any significant effect on the approach speeds of vehicles at intersections.

\section{Traffic Signs}

Warning signs have not been found to be very effective in reducing vehicle speeds. At the intersection of a minor road with a major road the "stop" sign will produce a greater reduction in approach speed than w1ll a "slow" sign or no sign at all.

Speeds are more nearly uniform on curves marked with "safe speed" signs than on unarked curves. These "safe speed" signs tend to eliminate the surprise element of low speed curves.

\section{Pavement Markings}

Pavements with center-line markings have higher average speeds than those without center-line markings. The marking of no-passing zones results in a slight decrease (two to three mph) in averago speed. There is some disagreement in the literature concerning the effect of rural highway "pavement-edge" markings on average speeds; however, the effect, if there is any, is to increase average speeds at night by a very slight amount. 


\section{Speed Limits}

Properly established speed zones assist the motorist in selecting speeds that are safe, and permit him to obtain the maximum utility, econom, and convenience from his vehicle and the road. In general, drivers tend to observe speed limits that are reasonable, proper, and safe for existing travel conditions and disregard speed limits that are unreasonably high or low. The best way to detemine a reasonable, proper, and safe speed limit for a particular location appears to be by measuring the speed below which a high percentage (85-90\%) of the motorists travel.

Mintmum speed limits, especially on high speed freeways and other major facilities, are very desirable and promote safety.

\section{Roadside Development}

Concentrated commerclal development apparently has a substant1al Influence on speed. Residential development also decreases speed but to a lesser degree than does commerclal development. The appearance of residential development seems to have a greater Influence on the driver's selection of speed than does the actual density of development.

The studies reviewed all supported the idea that speed is significantly affected by the different types of roadside development.

\section{Other Characterist1cs}

There are several other characteristics affecting speed which could not loglcally be discussed under any of the prevlous toptcs.

\section{Driver}

Several driver characteristics have been studied that have not been mentioned prevlously. 
Sex: Apparently women drivers travel at about the same or at a slightly lower average speed than men. Divorced men and women and single women seem to drive slightly faster than married men or women.

Age: There is little consistency in the literature conceming the effect of drivers age on vehicle speeds. Probably there are other physical and psychological pactors which cause this inconsistency. The effect of age on average speeds, in any event, is not large.

Lone drivers: Lone drivers tend to drive faster than drivers with passengers with them.

Ownership: Men owndng the vehicle they are driving tend to travel slightly slower than those not owning the vehicle they are driving.

Occupation: Salesmen and those engaged in the professions tend to drive above the average speed. These men are usually on longer trips and drive newer cars than the average driver, factors which themselves are characteristics of high speed.

Driving experience: In general, the length of driving experience for men has ifttle effect on vehicular speed, while the average speed of women drivers increases as the number of years of driving experience increases.

Annual travel: On the average, drivers with higher annual mileages travel at higher speeds than those with lower annual mileages.

Att1tude: One author reported that 21 percent of the variation in driving speed can be attributed to variation in drivers' attitudes.

\section{Veh1cle}

other vehicle characteristics which have been studied and have not been previously discussed include age, weight, and horsepower. 
Age: For equal travel distances, the average vehlcle speed decreases as the vehicle age increases. The rate of decrease is slightly greater for the older vehicles.

Weight and Power: On the average, heavier passenger cars are driven somewhat faster than lighter ones. For trucks there is some indication that speeds vary with vehicle weight and with power, especially for lowpowered trucks.

Both the average speed of travel and the horsepower of the automobile have been increasing over the years, but for passenger cars with over 100 horsepower there appears to be little relationship between average speed and horsepower.

\section{Speed Advertisements}

For several decades many persons have been concerned about automobile advertising of the "high speed vehicle". They claimed that this would have a psychological effect on drivers and increase their desire for speed. No Information was found in the literature of and studies of the effect, if any, such advertising has acturlly had on vehicle speeds.

\section{Pneumat1c Road Tubes}

One study revealed that the presence of pneumatic road tubes on the pavement produced a significant blas in measured speeds as opposed to actual speeds. The error was found to be non-systematic and impossible of correction by use of a factor.

\section{Speed and Accidents}

Accidents occur at all speeds and there is considerable doubt that speed is more than a contributing factor to the severity of the accident 
in most cases. Higher speeds do result in increased accident severity. Speed to fast for conditions is also a factor in some accidents but such a speed may be a slow speed or a high speed. Most certainly the reduction of speeds will not solve the accident problem or provide the benefits of modern motor vehicle transportation. 
BIBLIOGRAPHY .. 
BIBLIOGR.APHY

1. A Policy on Arterial Highways in Urban Areas, Washington, D. C., American Association of State Highway Orficials, pp. 116-121, 1957.

2. A Policy on Ceometric Lesign of Fural Highwaye, washington, D. C., American Association of State Highway Officials, pp. 78-94, 128-133, $165-171,262-261,433-434,442,452-454,481-482,1954$.

3. "A Timer to ind Speeding." The American City, Vol. 67, No. 8, pp. 149153. August 1952.

4. Adler, Charles, Jr., "Speed Space System for Safer Highways," Traffic Enfinecrine, Vol. 23, No. 9, p. 315, tune 1953.

5. "Alcohol and Speed," American City, Vol. 65, No. 10, p. 139, October 1950.

6. Allgaier, Farl, "Who Are Our Fast Drivers?" Safety Fncineering, Vol. 75, No. 2, pp. 2?-30, February 1938.

7. "A.H.A. Urges Dealers to Curb Speed Advertisine," Safetr, Vo1. 23, No. 1, p. 21, September 1936.

8. "Analysis of Speed Study Data," Planning and Traffic Division, Michigan State "ighway Lepartmont, December 1955.

9. "Are Traffic Accicents Caused by Speed?" American City, Vol. 44, No. $6, \mathrm{p} .129$, June 1931.

10. Automobile Facts and Fiqures, Automobile Manufacturers Association, Inc., Detroit, Michigan, 1962.

11. Avery, E. V., "Effect of Raising Speed Linits on Urban Arterial Streets," Highway Kesearch Board, Bulletin 244, pp. 88-97, 1960.

12. Avery, E. V. "Speed Zoning Results - A Before-After Comparison," City of Saint Paul, Department of Public Works, Traffic Bureau, May 1958.

13. Baerwald, John E., Annotated Bibliography on Motor Vehicle Speeds, Department of Civil Engineering, University of Illinois, Uroana, Illinois, January 1959.

14. Baerwald, John E., "Current Characteristics of Rural Motor Vehicle Speeds in Indiana," Proceedings, Highway Research Board, Vol. 34, p. 473, 1955. 
15. Baerwald, John E., "Indiana Traffic Speeds," Engineering Reprint No. 79, Purdue Engineering Experiment Station, pp. 40-51, March 1953.

16. Baerwald, John E., "Indlana Traffic Speeds 1942-1952," Proceedings of the 38 th Annual Road School - 1952, Purdue Engineering Bulletin No. 78 .

17. Baerwald, John E., "Theory of Speed Zones in Developed Areas," TrafPic Engineering, Vol. 28, No. 3, p. 20, December 1957. University of Wisconsin Traffic Engineering Institute, February 20, 1957.

18. Baker, James S., "Rffect of Enforcement on Vehicle Speeds," Highway Research Board, BulletIn 91, p. 33, January 1954.

19. Baker, James S., "The Higher the Speed the Worse the Acc1dent," Publ1c Safety, Vol. 6, No. 2, pp. 6-9, February 1932.

20. Baldock, R. H., "H1ghway Design for Speeds up to 100 Milles Per Hour," Engineering News Record, Vol. 114, No. 21, pp. 732-734, 1935.

21. Barnett, Joseph, "Deslgn Loads for Guardra1ls," Proceedings, Highway Research Board, Vo1. 19, pp. 138-141, 1939.

22. Barnett, Joseph, "Safe Side Friction Factors and Superelevation Design," Proceedings, Highway Research Board, Vol. 16, pp. 69-76, 1936.

23. Barret, James R., "Slow Down -- and Live," Casualty and Surety Journal, Vol. 15, No. 1, pp. 19-25, January 1954.

24. Beakey, John, "Regulation of Speed in Rural and Suburban Areas," Oregon State H1ghway Department, (Presented before the Traffic Engineering Committee of the American Association of State Highway officials, Seattle, Washington, September 17, 1940) unpublished.

25. Berry, Donald S., "A Report on the Status of the Problem of Vehicular Speed Control," University of California Institute of Transportation and Traffic Engineering, pp. 1-18, 1951.

26. Berry, Donald S., "Speed Control," Proceedings, American Association of State Highway officials, pp. 361-368, 1948.

27. Berry, Frank C., "Too Fast," Public Safety, Vol. 12, No. 5, pp. 18, 19, 44, May 1937.

28. Billion, C. E., "Effect of Median Dividers on Driver Behavior," Highway Research Board, Bulletin 137, pp. 9-11, 1956.

29. Blackmore, D. H., "Effect on Vehicle Speeds of Imposing a $40 \mathrm{MPH}$ Speed Limit in the London Traffic Area," The Surveror, Vol. 118, No. 3505 , pp. 634-635, London, 1959. 
30. Branham, A. K., "An Automatic Traffic Speed Recorder," Engineering Experiment Station, Purdue University, Reprint No. 7, pp. 348-359, September 1942. Proceedings, Highway Research Board, Vol. 21, p. $348,1941$.

31. Branham, A. K., "An Epoch of Traffic Research," Engineering Bulletin, Purdue Untversity, Vol. 28, No. 2, pp. 112-115, March 1944, (ProceedIngs of the Thirtieth Annual Road School, held at Purdue University).

32. Brosseau, A. J., "New Speed Laws for a New Era," Annals of the American Academy of Political and Social Science, Vol. 133, pp. 134-139, September 1927.

33. Burch, Robert A., "1947, Acc1dent Causes," Traffic Engineering, Vol. 18, No. 10, pp. 451-453, July 1948.

34. Burch, James S., "Toward a Better Accident Record," Better Roads, Vol. 7, No. Il, pp. 28, 33-34, November 1937.

35. Cumpbell, E. W., L. E. Keefer, and R. W. Adams, "A Method for Predicting Speeds Through Signalized Street Sections," Highway Research Board, Bulletin 230, pp. 112-125, 1959.

36. Carnichael, Thomas J., "Motor-Vehicle Performance and Highway Saf"ety," Proceedings, Highway Research Board, Vol. 32, pp. 414-420, 1953.

37. Camalchael, Thomas J., and C. E. Haley, "A Study of Vehicle, Roadway, and Traffic Relationships by Means of Statistical Instruments," Proceedings, Highway Research Board, Vol. 30, pp. 282-295, 1950.

38. Carsten, H. H., "Inform the Driver," Traffic Engineering, Vol. 28, No. 4, pp. 17-19, January 1958.

39. Carter, F. M., "Speed Zoning," First California Institute on Street and Highway Problems, Technical Bulletin No. 1, p. 151, February 1949.

40. Cato, E. Raymond, "Are We Getting Anywhere with Speed Controls?" Transactions, National Safety Council, Vol. 23, pp. 24-25, October 1934.

41. Cato, E. Raymond, "Speeding to Destruction," National Salety News, Vol. 32, No. 4, pp. 47-48, October 1935.

42. Cato, E. Raymond, "What $C_{3}$ W Wo Do About Speed and Accidents?" Transactions, National Safety Council, Vol. 26, pp. 7-9, October 1937.

43. Charlesworth, G. and T. M. Coburn, "Influence of Road Layout on Speeds and Accidents in Rural Areas," Journal, Institution of Municipal Engineers, Vol. 83, No. 7, January 1957. 
44. Chastain, J. D., "The Effect of 0.01 Per Cent Blood Alcohol on Driving Ability," Traffic Safety, Research Review, Vol. 5, No. 3, pp. 4-8, September 1961.

45. Claffey, P. J., "Characteristics of Passenger-Car Travel on Toll Roads and Comparable Free Roads for Highway User Benefit Studies," Public Ro:ds, Vol. 31, No. 8, pp. 167-176, June 1961.

46. Cla1r, Robert, "The High Speed Motif in Automoblle Ads," Public Salety, Vol. 5, NNo. 7, pp. 4-5, July 1931.

47. Cleveland, D. E., "Driver Characteristics and Speed Performance Related to the Facility," Highway Research Board, Bulletin 212, pp. 1-10, 1959.

48. Coburn, T. M. and N.C. Duncan, "The Effect on Speeds and Accidents of a $30 \mathrm{MPH}$ speed Iimit in Built-Up Areas in Northern Ireland," International Road Safety and Traffic Review, Vol. VII, No. 3, Sumer, 1959.

49. Coleman, Robert R., "The Effect of Speed Limit Signs," Traffic Engineering, Vol. 27, No. 4, p. 176, January 1957.

50. Collins, John $\mathrm{H}$. and C. A. Hart, Principles of Road Englneering, .. Edward Arnold and Company, Great Britain, pp. 57-61, 71, 1938.

51. "Comparison of Speeds on the Rural State Trunkline System Before and ffter Enactment of the 65-55 MPH Speed Law," Planning and Traffic Division, Michigan State Highway Department, 9 pages, 1956. (April 1955-April 1256)

52. "Compurison of $35 \mathrm{MPH}$ with $45 \mathrm{MPH}$ as Maximum Speed Regulation for Truck and Passenger Stage Operation Under War Conditions," California Railroad Comission-Transportation Department Engineering Division, January 1943.

53. Conradt, Robert, "Sneed Iimits in New Mextco," Trafilc Quarterly, Vol. 7, No. 4, p. 517, October 1953.

54. Coons, Harry C., "How Modern Highway Design Reduces Accidents," Public Works, Vol. 78, No. 9, pp. 2l-24, 34, September 1947.

55. Copell, E. T., 'Design of Highways and Intersections Comparable with Speed of Motor Traffic," American Highways, Vol. 17, No. 1, pp. 16-18, January 1938.

56. "Counc1l Managers Say Slow Driver is Scapegoat," Traffle Digest and Review, Vol. 2, No. 7, p. 21, July 1954.

57. Crider, John H., "Speed whth Ease," Scientific American, Vol. 155, pp. 330-332, December 1936. 
58. "Critical Speeds at BIind Intersections," National Safety Council Inc., Public Saf etr Meno 73, pp. 1-11 August 1943.

59. Crowther, Richard F., R. P. Shumate, and R. D. Srith, wThe Effect of Pneumatic Road Tubes on Vehicle Speeds," Praffic Safety, Research Review, Vol. 5, No. 3, pp. 12-28, September 1961.

60. Darrell, J. E. P., "Report of Subcomittee on Speed Control," Proceedings, Amertcan Association of State Highway Officials, p. 391 , 1950 .

61. Darrell, J. E. P., "Speed Trend Surveys 1960," State of Minnesota, Department of Highways, St. Paul, Minnesota, March 1961.

62. Darrell, J. E. P., "Speed Thend Surveys 1961," State of Minnesota, Department of Highways, St. Paul, Minnesota, February 1962.

63. Darrell, J. E. P., J. E. Johnston, T. E. Thanseau, and C. C. Wlley, "What About Speed Limits," Proceedings, Institute of Traffic Engineers, p. $42,195 \mathrm{C}$.

64. Deen, T. B., "Effectiveness of Speed Iimit Signs," Traffic Engineering, Vol. 29, No. 7, p. 22, April 1959.

65. DeSilve, Harry R., "A Stuay of Motor-Vehicle Drivers and Speed in Connecticut," Public Roads, Vol. 21, No. 5, pp. 89-100, Julg 1940.

66. DeS1lva, Herry R., "Results from Speed Studies in Connecticut and South Carolina," Proceedings, Highway Research Board, Vol. 20, p. 702, 1940 .

67. DeSilva, Harry R., Why We Have Automobile Accidents, John Wiley and Sons, London, pp. 33-54, 359, 1942.

68. Dickinson, H. C. and C. F. Marvin, Jr., "What is Safe Speed?" Journal, Soclety of Automotive Engineers, Vol. 17, p. 81, July 1925.

69. "Driver Behavior Study--Speed Characteristics on Rural Highways," New York State Department of Public Works, Bureau of Highway Planning, 1953-1954, unpublished.

70. "Dr1ving Habits at Night," Better Roads, Vol. 10, No. 3, p. 34, March 1940.

71. "Driving Speeds Steady Despite Alterat1on of Posted Rates," Cuts and Fillo, Vol. 5, No. 11, November 1946. Highway Research Abstracts, Vol. 17, No. 137, p. 10, January 1947.

72. Dunn, Robert E., "Motor Vehicle Performance on Ascending Grades," Highway Research Board, Bulletin 194, pp. 12-20, 1955. 
73. Eaton, Ralph W., "Supervision and Control of Speed in Municipalities with Special Reference to State Highway Traversing Them," Proceedings, Institute of Traffic Engineers, Vol. 6, pp. 10-19, October 1935.

74. Eddy, Robert C., "Interesting Phases of the Massachusetts Highway Accident Survey," Proceedings, Institute of Trafic Engineers, Vol. 5. pp. 79-80, October 1934.

75. Edwards, H. M., "Vehicle Speeds on Ontario Highways," Department of Civil Engineerlng, zueen's University of Kingston, Report No. 3, August 1958, unpublished.

76. "Effect of Speed Zone S1gns and Advance Speed Reduction Signs on Speed Habits," Highway Research Abstracts, Vol. 21, No. 8, p. 15, Septeraber 1951.

77. Eldridge, M. O., "Praffic," Amertcan Road Builders' Association, lechrical Bulletin No. 23, pp. 37-45, 1931.

78. Flot, Willam G., 'Discussion After Supervision and Control of Speed in Municipalit1es, " Proceedings. Institute of Traffic Engineers, pp. 19-21, October 1935.

79. Eliot, Wiliam G., "The Rising Accident Rate," Public Roads, Vol. 16. No. 1, pp. 8-9, Mrrch 1935.

80. Eliot, William G., "Types of Regulation Aflect Driving Habits," Civil Engineering, Vol. 5, No. 9, pp. 528-531, 1935.

81. Elmberg, Curt M., "Effects of Speed Zoning in Suburban Areas," Jolnt Híghway Research Project, Purdue University, No. 9, June 1960.

82. Elmberg, Curt M., "Speed Patterns at a School Crossing in West Lafayette, Indiana, "Report, Purdue University, October 1959. (Unpublished)

83. Elmberg, Curt M., and H. L. Michrel, "Effect of Speed Limit Signs on Speed on Suburban Arterial Streets," Highway Research Board, Bulletin No. 303 , pp. 1-9, 1961.

84. Elmberg, Curt M. and H. I. Michiel, "The Effect on Speed of Speed Limit Signs on Suburban Arterial Streets," Jolnt Highway Research Project, Purdue University, No. 4, January 1961.

85. Evans, Henry K., Traffic Engineering Handbook, Institute of Traffic Engineers, New Haven, Connecticut, pp. 65-79, 152-158, 165-166, 331 $391,1950$.

86. "Excessive Speed A Major Frctor in Highway Accidents," American City, Vol. 49, No. 3, pp. 75, 77, March 1934. 
87. "Fatalities on California Freeways, 1955," California Highways and Public Worl:s, pe. 18-20, INovember-December 1956.

88. Faustman, D. J., "One-Way-Street-Plan for Sacramento," Proceedings, The Second Calffornia Institute on Street and Highway Problems, University of California, Los Angeles, pp. 120-121, January 1950.

89. Finestone, A. L., et aI, "Speed Emphasis in Advertisements," Nation's Traffic, Voi. 2, No. 12, pp. 22-23, March and April 1928.

90. Fish, Caman 's., "Are Speed Limits Obsolete?" National Safety News, Vol. 23, pp. 21, 24, February 1931.

91. Forbes, T. l., "Speed, Headway, and Volume Relationships on a Freeway," Proceedings, Institute of Traffic Engineers, pp. 103-126, 1951.

92. Forbes, T. K., and M. S. Katz, Driver Behavior and Highway Conditions as Causes of siinter Accidents," Highway Research Board, Bulletin 161, pp. 18-29, 1957.

93. Forbes, T. W. and T. M. Matson, "Driver Judgnents in Passing on the Highway," The Journil of Psychology, Vol. 8, pp. 3-11, 1939.

94. Forney, Robert B., F. W. Hughes, H. R. Hulpleu, and Lt. C. A. Davis, Performance in a Gumihana Sports Car Event with Low Levels of Blood Alcohol," lraffic Safety, Research Review, Vol. 5, No. 3, pp. 8-12, September 1961.

95. Fox, Merrit L., "Relations Between Curvature and Speed," Proceedings, li1ghway Research Board, Vol. 17, pp. 202-211, 1937.

96. Franilin, Jerome D., "Speed Data Provided by Radar Checks," Public Works, Vol. 86, No. 1, p. 117, January 1955.

97. Frost, R. E., "Indiana Wartime Traffic Speeds," Purdue University Englneering Experiment Station, Reprint No. 10, p. 395, December 1944.

98. Frost, R. E., "Some Factors Affecting Trafflc Speeds," Purdue University Engineering Experiment Station, Fight Progress Report, Part B, June 1942. (Unpublished Thesis)

99. Frost, R. E., "The Use of Speed-Recorder Equipment," Engineering Bulletin, Purdue University, Vol. 26, No. 2, pp. 102-106, March 1942 (Proceedings of the 'Iwenty-Eighth Annual Road School held at Purdue University).

100. Gallagher, R. S., "The Case for Standard Speeds," The Surveyor, London, Vol. 110, No. 3103, pp. 535-537, August 25, 1951.

101. "Gallup Poll on Speed," Public Safety Magazine, August 1939, Highway Research Abstracts, No. 63, p. 6, September 1939. 
102. Garwood, F. and J. T. Duff, "Changes in Accident Frequency After Changes in Speed Limits in the United Kingdom," Fifth International Study Week in Trat'fic Engineering, N1ce, 1960 .

1C3. Ceorge, H. P., "Measurement and Evaluation of Traffic Congestion," Unality and Theory of Traffic Flow, Bureau of Highway Traffic, Yale

104. George, H. P., "Traffic Behavior and Road Capacity Study," Victoria Country Rozd Boards, Melbourne, 1955, Memorandum No. 12; Road Abstract, Great Britain Scientific and Industrial Research Department,
Vol. 22, No. 11, p. 172, 1955.

105. Giessler, Wro. C., "headiamps and Road Speeds," Public Safety, Vol. 12., No. 3, pp. 12-14, March 1937.

106. Goldstein, L. F. and J. N. Mosel, "A Factor Study of Drivers' Att1tudes, with Further Study on Driver Aggression," Highway Research Board, Bulletin 172, pp. 9-29, 1958.

107. Coltz, E., "Speed and Traffic Capacity," Auto-Technical Z, Vol. 56, No. 5, pp. 125-127, 1954. "Roid Abstracts (Department of Scientific and Industrial Research, Road Research Laboratory) London, Vol. XXII, No. $3, \mathrm{p} .44$.

108. Greenshields, Bruce D., "A Study of Traffic Capacity," proceedings, Highway Research Board, Vol. 14, pp. 448-472, 1934.

109. Greenshields, Bruce D., "Distance and lime Required to Overtake and Pass Cars," Proceedings, Highway Research Board, Vol. 15, pp. 332$342,1935$.

110. Greenshields, Bruce D., "Reaction-Time and Traffic Behavior," Civil Engineering, Vol. 7, No. 6, pp. 384-386, 1937.

111. Greenshields, Bruce D., "Studying Traffic Capacity, by New Methods," Civil Engineering, Vol. 5, No. 5, pp. 301-304, 1935.

112. Greenshields, Bruce D., "The Density Fuctor in Traffic Flow," Traffic Engineering, Vol. 30, No. 6, pp. 26-28, 30, March 1960.

113. Greenshields, Bruce D., "The Photographic Method of Studying Traffic Behavior," Proceedings, Highway Research Board, Vol. 13, pp. 382$396,1933$.

114. Greenshtelds, Bruce D. and F. M. Weida, Statistics with Application to Highway Traffic Analysis, The Eno Foundation for Highway Traffic Control, Sigatuck, Connecticut, 1952.

115. Greenshields, Bruce D., et al., "Traffic Performance at Urban Street Intersections," l'echnical Report No. 1, Yale Bureau of Highway Traffic, pp. 1-71, 1947 . 
116. Guerin, N. S., "Travel Time Relationships," Quality and Theory of Traffic Flow, Bureau of Highway Traffic, Yale University, pp. 69$103,1961$.

117. Guyton, Joseph $\because$ and A. K. Stonecipher, "Sampling Frocedures for Determining Speed Characteristics at Fural Locations, "Highway Research Board, Bulletin 208, po. 64-83, 1958.

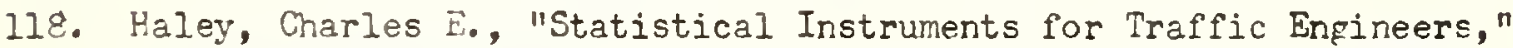
Traffic Enfineering, Vol. 21, No. 12, pp. 4C3-405, September 1951.

119. "Half of Trucks Prceeding Pennsylvania Turnpike I imits, "Highway Research Abstracts, Vol. 23, No. 2, n. 1, February 1953, Motor Truck News, Vol. 41, No. 11, p. 11, November 1952.

120. Halsey, Maxwell, "Higt.way Economic and Vesign Principles," Proceedines, American Road Builders' Association, Vol. 37, pp. 74$8 \mathrm{BC}, 1,4 \mathrm{C}$.

121. halsey, Haxhell, "Speed Survey," hmericen City, Vol. 49, No. 3, p. 77, March 1934.

122. Halsey, Naxwell, "Speed on Thoroughfares," Iraffic Refulation, Vol. 1, No. 6, op. 195-198, Mey 1931.

123. Halsey, Naxwell, "The Relation of Accidents to Concestion," Proceedings, American foad Builders' Association, Vol. 37, p. $2 \overline{87}$, 1940.

124. Halsey, Narwel], Traffic Accidents and Congestion, John Wiley and Sons, Inc., New York, pp. 3-12, 35, 42-49, 119, 145-146, 251-254, 1941.

125. Halsey, Maxwell, et al., "Speed as a Cause of Traffic iccicents," American City, Vol. 48, №. 2, pp. 73-75, 1933.

126. Hamilton, J. R. and L. L. Thurstone, Safe Driving, Doubleday, Doran and Coripany, Inc., Garden City, 1. Y., 74 pages, 1937.

127. Hammond, Harold F., "liore Speed or Less After the W'ar?" Better Roads, Vol. 14, 11o. 5, pp. 18-20, 30, Nay 1944.

128. Harrison, harry H., "Speed and Accidents," Public Safety, Vol. 13, No. 5, pp. 26-2?, November 1937.

129. Harrold, D. Hunter, "Rural Accident Investigation in the State of Washington," Traffic Enfineering, Vol. 12, No. 13, pp. 362-364, Nay 25, 1942.

130. Head, J. Al., "Indicated Speeds on Oregon Freeways," Present to the loth Annual Northwest Traffic Engineering Conference, University of Washington, April 11-12, 1957, unpublished. 
131. Helwer, Sam, "Traff1c Interchange Design," California H1ghways and Public Works, Vol. 30 , Nos. $3,4, \mathrm{pp} .50-54$, August 1756.

132. Hewes, Laurence $I_{\text {. }}$ and Clarkson H. Oglesby, Highway Engineering, John Wiley and Sons, Inc., New York, pp. 42-54, 139-154, 160-1ól, $170-175,180-197,1954$.

133. Hyghway Capacity Manual, U. S. Department of Comerce, Bureau of Public Roads, Washington D. C., U. S. Goverment Printing Office. pp. 17, 27-63, 1950 .

134. "Highway Kenace: Slow Poke is Highway Problem," California Patrolman, Vol. 19, No. 8, pp. 27, 66-67, 1955, Highway Research Abstracts, Vol. 26, No. 1, p. 17, January 1956.

135. Highway Practice in the U. S. A., Public Roads Administration, Federal Works Agency, Washington, D. C., U. S. Government Printing offlce, Washington, pp. 64-77, 1949.

136. "Highway Radar 1s Watching You," Nation's Business, Vol. 43, No. 8, p. 38, 40, 95, 97, September 1955.

137. "Highway Speed Limits," Engineering News Record, Vol. 97, p. 127, July 22, 1926.

138. Hill, G. Albert, "Speed Control by Traffic Signel," Traffic Quarterly, Vol. 8, No. 1, pp. 5-12, January 1954.

139. Hirsch, Phil, "Radar Reduces Accidents," Public Works, Vol. 86, No. 7, pp. 83-84, July 1955.

140. Hof fman, Rayburn, "The 130' Campaign in St. Louis," The Amer1can City, American C1ty Magazine Corporation, New York, Vol. 51, No. 12, pp. 51-52, 1936.

141. Hoke, Trav1s, "Shall Speed Laws be Abolished?" Popular Sclence Monthly, Vol. 116, No. 2, pp. 19-21, 144-145, February 1930.

142. Holmes, E. H., "Current and Postwar Automob1le Speeds," Traffic Engineering, Vol. XIV, No. 7, p. 150, April 1944.

143. Holmes, E. H., "Procedure Bmployed in Analyzing Passing Practlces of Motor Vehícles," Public Roads, Vol. 19, No. 11, pp. 209-212, 221, January 1939.

144. Holmes, E. H. and S. E. Reymer, "New Techniques in TrapPlc Behavior Studies," Public Roads, Vol. 21, No. 2, pp. 20-45, April 1940.

145. Homburger, Wolfgang S., "The Behavior of Drivers at Uncontrolled Intersections, "Trafftc Engineering, Vol. 22, No. 3, pp. 105-108, December 1951. 
146. Homburger, Wolfgang S., "The Effect of the New State-Wide Speed Limit in California on Motor Vehicle Speeds," Technical Memorandum B-43. Institute of Transportation and Traffic Englneering, Berkeley, California, January 1961.

147. Horn, J. W., P. D. Cribbins, J. D. Blackburn, and C. E. Vick, Jr., "Investigations of the Effects of Commercial Roadside Development on Flow in North Carolina," Highway Research Program, North Carolina State College, Raleigh, North Carolina, January 1961.

148. Horn, John W., P. D. Cribbins, J. D. Blackburn, and C. E. Vick, Jr., "The Effect of Commercial Roadside Development on Traffic Operations," Highway Research Program, North Carollna State College, Ralelgh, North Carolina, pp. 18-25, June 1960.

149. "How Fast," IIlinois Highway Bulletin, Division of Highways, Vol. 21, Nos. 5 and 6, May and June 1955.

150. Huber, M. J., "Effect of Temporary Bridge on Parkway Performance," Highway Research Board, Bulletin 167, pp. 63-74, 1957.

151. "Is Fifty Mile Limit Too Low in Pennsylvania?" Pennsylvania Road Builder, Vol. 29, No. 4; p. 1I, April 1956; Highway Research Abstracts, p. 11, June 1956.

152. Jackman, W. T., "Driver Obedience to Stop and Slow Signs," Highway Research Board, Bulletin 161, pp. 9-17, 1957.

153. Johnson, Arnold A., "Maximum Safe Vehicle Speods at Railroad Grade Crossings," Praffic Engineering, Vol. 28, No. 9, pp. 20-22, June 1958.

154. Johnson, A. N., "Notes on Traffic Speeds," Proceedings, Highway Research Board, Vol. 13, pp. 351-360, 1933.

155. Johnson, H. W., "Well Tell You - A Panel Discussion," Transactions, 30 th National Safety Congress, Vol. 30, pp. 26-28, October 1941.

156. Johnston, J. E., "How About Vehicle Speeds?" Traffic Quarterly, Vol. 5, No. 3, p. 325-335, July 1951.

157. Johnston, J. E., "Slow Traffic Laws Waste Fast Roads," Nation's Business, Vol. 44, No. 4, p. 32, April 1956.

158. Johnston, J. E. "Speed Control and Regulation," Proceedings, Institute of Traff1c Engineers, p. 141, October 26, 1955.

159. Jouzy, Neddy, "Use of Acceleration and Deceleration Lanes," Joint H1ghway Research Project, Purdue University, No. 1, February 1962.

160. Kearney, Paul $W_{0}$, How to Drive Better and Avold Accidents, Thomas Y. Crowell Company, New York, pp. 108-125, 1953. 
161. Keefer, Louis $E_{0}$, "The Relation Between Speed and Volume on Urban Streets," Chicago Area Transportation Study, January 1958, unpublished.

162. Keese, C. J., C. Pinnell, and W. R. McCasland, "A Study of Freeway Traffic Operation," Highway Research Board, Bulletin 235, pp. 73$132,1960$.

163. Keese, C. J., and R. H. Schleider, "Correlation of Design and Operational Characteristics of Expressways in Texas," Highway Research Board, Bulletin 170, pp. 1-23, 1958.

164. Kelly, Joseph C., "1958 Annual Report," New York State Traffic Commission, pp. $21_{4}-28$.

165. Kemper, James S., "Some Thoughts on Safe Driving," Safety Engineering, Vol. 72 , No. 5, Pp. 25-28, November 1936.

166. Kent, M. F., "Fuel and Time Consumption Rates for Trucks in Freight Service," Highway Research Board, Bulletin 276, pp. 1-19, 1960.

167. Kent, M. F., "Fuel and Time Consumption Rates for Trucks in Freight Service," Public Roads, Vol. 31, No. I, pp. 22-3I, April 1960.

168. Kessler, Warren L., "The Effect of Altering or Establishing Speed Zones on Illinois Highways on the Basis of Engineering Investigations," Bureau of Traffic, Illinois Division of Highways, Springfield, IIinois, 1959 (Synopsis).

169. Kessler, Warren L., "The Effect of Speed Zone Modifications Occasioned by the Illinois Speed Irw," Mrafic Engineering, Vol. 29, No. 10, p. 18, July 1959.

170. Knudson, James K., "The Auto Makers' Responsibility," Vital Speeches of the Day, Vol. 19, pp. 348-352, 1953.

171. Koester, Edwin F., "Speed and Accident Control Through S1gnalization," Irafic Ensineering, Vol. 16, №. 4, pp. 127-132, January 1946.

172. Lauer, A. R., "A Sampling of Drivers on the Highways for the 24-Hour Period," Highway Research Board, Bulletin 73, p. 14, 1953.

173. Lawshe, C. H., Jr., MApproach Speeds and Changes in Sign Size and Location on the Highway," Journal of Applied Psychology, Vol. 24, 1940.

174. Lawshe, C. H., Jr., "Some Driver Opinions and Their Relationship to Speed on the Open Highway," Journal of Applied Psychology, Vol. 24, 1940 .

175. Lawshe, C. H., Jr., "Studies in Automobile Speed on the Highway," Journal of Applied Psychology Vol. 24, pp. 297, 324, 1940. 
176. Lef'eve, B. A., "Relation of Accidents to Speed Habits and Other Driver Characteristics," Highway Research Board, Bulletin 120, p. 6, 1956 .

177. Lefeve, B. A., "Speed Characteristics on Vertical Curves," Proceedings, Highway Research Board, Vol. 32, pp. 395-413, 1953.

178. Lefeve, B. A., "Speed Habits Observed on a Rural Highway," Proceedings, Highway Research Board, Vol. 33, p. 409, 1954.

179. Lord, A. L., "Safety with Covernors," Safety, Vol. 31, No. 9, pp. 21,2-243, September 134.

180. Lorentzen, Kay, "Speed Traps and Safety," Traffic Engineering, Vol. 26, No. 4, p. 167, January 1956.

181. Loutzenheiser, D. W., "Highways with a Narrow Median -- Synopsis," Highway Research Board, Bulletin 35, pp. 1-2, 1951.

182. Loutzenheiser, D. H., "Percentile Speeds on Existing Highway Tangents," Proceedings, Highway Research Board, Vol. 20, pp. 372-389, 1940.

183. Iynch, J. T., "Current Trends in the Volume Characteristics of Highway Traffic," Proceedings, Highway Research Board, Vol. 23, pp. 350-362, 1943.

184. MMjority of Fatalities on Pennsylvania Turnpike Occur on Lower Speed Limit Sect1ons," Transport Topics, No. 970, p. 12, March 15, 1954.

185. Mlo, A. F., H. S. Mika, and V. P. Walbridge, "Traffic Behavior on an Urban Expressway," Highway Research Board, Bulletin 235, pp. 19$37,196 C$.

186. Manton, B. G., The Road and the Vehicle, Edward Arnold Company, London, pp. 41-42, 151, 1953.

187. Marsh, Burton $h_{.}$, "More Flexibility is Needed in Traffic Control," Traffic quarterly, Vol. 9, No. 3, pp. 431-446, July 1955.

188. March, Burton W., "Report of Comnittee on Light as Affecting Highway Travel at Night," Proceedings, Highway Research Board, Vol. 19, pp. 271, 274, 1939.

189. Mathewson, J. H., "A Segmented Electrical Element for Detecting Vehicular Traffic," Proceedings, Highway Research Board, Vol. 29, pp. $374-382,1949$.

190. Matson, T. M. and T. W. Forbes, "Overtaking and Passing Requirements as Determined from a Moving Vehicle," Proceedings, Highway Research Board, Vol. 18, pp. 100-112, 1938. 
191. Matson, T. M. W. S. Smith, and $F_{0}$. W. Hurd, Traffic Engineering, McGraw-Hill Book Company, Inc., New York, pp. 45-66, 130-147, $162-164,205-259,376-392,1955$.

192. May, A. D., Jr., "A Friction Concept of Traffic Flow," Proceedings, Highway Research Board, Vol. 38, pp. 493-510, 1959.

193. May, A. D., Jr., "Characteristics of Traffic Flow on Freeways," Journal of the Highway Division, Proceedings of the American Society of Civil Engineers, Vol. 85, No. HW4, Pt. 1, pp. 1-21, December 1959.

194. May, A. D., Jr., "Economics of Operation on Limited Access Highways," H1ghway Research Board, Bulletin 107, pp. 49-62, 1955.

195. May, A. D., Jr., "Trafflc Characteristics and Phenomena of High Density Controlled Access Facilities, "Traffic Engineering, Vol. 31, No. 6, pp. 11-19, 56, March 1961 .

196. May, A. D., Ir., and F. A. Wagner, Ir., "Headway Characteristics and Interrelationships of Fundamental Characteristics of Traffic Flow," Proceedings, Highway Research Board, Vol. 39, pp. 524-547, 1960.

197. McClintock, Milier, "Higher Speeds with Safety," Safety, Vols. 24-25, No. 7, pp. 92-93, 1937.

198. McClintock, M1ller, "Speed," Review of Reviews, Vol. 96, No. 1, pp. 49-50, July 1937.

199. McClintock, Miller, "Speed Control Wlthout "Prima Facie' Rule," American City, Vol. 44, p. 137, January 1931.

200. McClintock, Miller, Street Traffic Control, McGraw-Hill Book Company, New York, pp. 92-94, 1925.

201. McCullough, C. B., "The Economics of Highway Alignment Design," Proceedings, Highway Research Board, Vol. 21, pp. 167-176, 1941.

202. McDevitt, Frank J., "Report or Comittee on Traffic," Proceedings, Amerlcan Road Builders' Association, Vol. 33, p. 565, 1936.

203. McDonald, Thomas H., "Witghway Safety," Public Roads, Vol. 25, No. 7, pp. 134-135, March 1949.

204. McIntyre, Lewis $h_{\text {., }}$ "Report of Committee on Traffic Engineering," Transactions, National Safety Council, Vol. 23, pp. 38-39, October 1934.

205. McMillan, Claude R., "South Carolina's New Speed Law," Traffic Quarterly, Vol. 11, No. 4, p. 492, October 1957. 
206. McMonagle, J. Carl, "Speed," Traffic Quarterly, Vol. 4, No. 4, p. 390. October 1950.

207. McMonagle, J. Carl, "The Need and Application of Speed Zoning," Proceedings, Institute of Traffic Engineers, p. 90, 1946.

208. Measuring Car Speeds," Public Safety, Vol. 4I, No. 4, p. 8, April 1952.

209. Meyer, Robert L., "Hourly and Da1ly Variation In Vehicle Speeds on a Rural H1ghway," Traffic Englneering, Vol. 21, No. 10, pp. 342-345, July 1951.

210. Michael, Harold L., "Characteristics of Travel on Indiana Highways," Purdue Engineering Experiment Station, Reprint No. 103, October 1954.

211. Michaels, R. M., "The Effects of Enforcement on Traffic Behavior," Public Roads, Vol. 31, No. 5, pp. 109-113, 124, December 1960.

212. Mickle, D. Grant, "Determination of Graduated Speed Regulations," . Proceedings, Conference on Highway Engt neering, University of Michigan, Vol. 23, pp. 14-25, 1937.

213. Mickle, D. Grant, "How Fast is Speed?" Public Safety, Vol. 15, No. 3, pp. 10-11, March 1939.

214. Mickle, D. Grant, "Report of Comittee on Speed Regulation," Transactions, 28th National Safety Congress, Vol. 28, pp. 33-34; October 1939.

215. Mickle, D. Grant, "Report of Special Study on Speed Zoning," Transactions, National Safety Council, Vol. 27, pp. 23-24, October 1938.

216. M1ckle, D. Grant, "Speed Zoning," American Highways, Vol. 17, No. 1, pp. 13-15, January 1938.

217. Miller, E. V., "Results of Speed Zoning," Transactions, National Safety Council, Vol. 30, pp. 46-48, October 1941.

218. Miller, F. D., "A Study of School Crossing Protection," Joint Highway Research Project, Purdue University, No. 25, September 1961.

219. Milton, T., "Fast and Safe," Collier's, Vol. 76, No. 5, pp. 18-19, August 1, 1925.

220. Minimum Speed Law in South Carolina," Quarterly Toll Review (American Bridge Tunnel and Turnpike Association, Inc.), pp. 20-21, Sumer 1958.

221. Mitchell, Adolphus, "Design of Acceleration and Deceleration Lanes," Transactions, American Soclety of C1vil Engineers, Vol. 107, No. 2138, pp. 494-504, 1942. 
222. Moffit, H. R., "Wisibility," American Road Builder's Association, Technical Bulletin No. 18, pp. 14-20, 1931.

223. Mohr, Harvey W., "Results of Speed Zoning on Rural Highways," Proceedings, Highway Research Board, Vol. 33, p. 429, 1954.

224. Moley, Raymond, "Speed, the Killer," News Week, Vol. 45, No. 26, p. 96, June 27, 1955.

225. Moore, Albert B., "Prima Facie Versus Absolute Speed Limits," Transactions, 28th National Safety Congress, Vol. 28, pp. 25-27, October 1939.

226. Moore, John 0., "A Preliminary Study of Speed as Rolated to InjuryProducing Automobile Accidents," Highway Research Board, Bulletin 142, pp. 11-18, 1956.

227. Morrison, Roger I., "What About Speed?" Public Safety, Vol. 13, No. 4, pp. 8-9, October 1937.

228. Moskowitz, Karl, "Research on Operating Characteristics of Freeways," Proceedings, Institute of Traffic Engineers, pp. 85-110, 1956.

229. Most Motorists Ignor Speed Limit Signs," California Highways and Public Works, Vol. 32, No. 9-10, p. 51, October, November 1953.

230. "Wotor Vehicle Speed ... Its Control and Regulation," American Automobile Association, Traff1c Engineering and Safety Dept.

231. Motor Vehicle Speeds, Annotated, Highway Research Board, Bibliography 27, 1960.

232. Motorists Now Help Design Highway by Recording Driving Habits on Tape," Safety, Vol. 27, No. 10, pp. 231-240, October 1940.

233. Moyer, R. A., "Further Skidding Tests with Particular Reference to Curves," Proceedings, Highway Research Board, Vol. 14, pp. 123-130, 1934.

234. Moyer, R. A., "Motor Vehicle Operating Costs and Relation Character1stics on Untreated Gravel and Portland Cement Concrete Road Surfaces," Proceedings, Highway Research Board, Vol. 19, pp. 68-98, 1939.

235. Moyer, R. A., "Motor Vehicle Power Requirements on Highway Grades," Proceedings, Highway Research Board, Vol. 14, pp. 147-186, 1934.

236. Moyer, R. A., "Speed Versus Safety on Curves," Civil Engineering, Vol. 7, No. 2, pp. 113-116, February 1937.

237. Moyer, R. A., "Speed Versus Safety on Stralghtways," Civfl Engineering, Vol. 6, No. 12, pp. 801-804, December 1936. 
238. Moyer, R. A. and D. S. Berry, Mark1ng Highway Curves with Safe ppeed Indications," Proceedings, Highway Research Board, Vol. 20,

239. Murphy, T. E. and E. J. Murphy, "Holiday from Death," The Rotarian, Vol. 53, No. 10, pp. 31-33, October 1938.

240. Myers, Hallie, "Promotion of Safety on the Highway," Engineering Bulletin, Purdue University, Vol. 22, No. 2, pp. 1-15, March 1938.

241. Neal, Harry E., "Vehicular Speeds in Ohio," Traffic Engineering, Vol. 14, No. 2, p. 34, November 1943.

242. Nichols, Charles G., "Let's Have Some 300 Horsepower Planning," American Highways, Vol. 34, No. 1, p. 9, January 1955.

243. "Night Driving and Headlight Lamps," Safety Engineering, Vol. 65, No. 4, p. 132, Apr11 1933.

244. "Night Gutde - A Side of Pavement Line," Engineering News Record, Vol. 154, No. 14, p. 45, Apr11 7, 1955.

245. "No Speed Limtt Changed on Ransas Turmpike," Roads and Streets, Vol. 100, p. 85 , June 1957.

246. Noble, Charles M., 'Developments in Curve Design, Speed and Sight Distance," Rosds and Streets, Vol. 85, No. 1, pp. 25-31, January 1942.

247. Noble, Charles M., "Engineering Design of Superhighways," ProceedIngs, American Road Bullders' Association, Vol. 38, pp. 195-196, 1941 .

248. Noble, Charles M., "Mhe Modern Express Highway," Proceedings, Anerican Society of Civil Engineers, Vol. 62, pp. 1013-1023, 1936.

249. Noble, Charles M., "Traffic Speed Policies," Traff1c Engineering, Vol. 16, No. 8, pp. 294-295, May 1946.

250. Normann, 0. K., "Highway Capacity," Proceedings, Highway Research Board, Vol. 21, pp. 379-392, 1941.

251. Normann, O.K., "Influence of Alignment on Operating Characteristics," Proceedings, H"ghway Research Board, Vol. 23, pp. 329-342, 1943.

252. Normann, O. K., "Influence of Driver Characteristics on Passenger Car Operation," Proceedings, Highway Research Board, Vol. 24, p. 318, 1944.

253. Normann, O. K., "Preliminary Results of Highway Capacity Studies," Publ1c Roads, Vol. 19, No. 12, pp. 225-232, 240, February 1939. 
254. Nomann, O. K., "Progress in Study of Motor-Vehicles Passing Practices," Public Roads, Vol. 20, No. 12, pp. 221-227, February 1940.

255. Normann, O. K., "Recent Trends in Traffic Speeds on Main Rural Highways," Proceedings, Highway Research Board, Vol. 2\%, pp. 362$374,1942$.

256. Normann, O.K., "Research to Improve Tomorrow's Traffic," Traffic Engineering, Vol. 29, No. 7, pp. 1I-21, April 1959.

257. Normann, O. K., "Results of Highway-Capacity Studies," Public Roads, Vol. 23, No. 4, pp. 58-64, June 1942.

258. Normann, O. K., "Studies of Motor Vehicle Operation on Ilghted and Unlighted Rural Highways in New Jersey," Proceedings, Highway Research Board, Vol. 24, p. 513, 1944 .

259. Nomann, O. K., "The Influence of Alignment on Operating Characteristics," Trafic Engineering, Vol. 14, No. 6, pp. 126-129, March 1944.

260. Normann, O.K. and W. P. Walker, "Highway Capacity; PracticaI Application of Research," Public Roads, Vol. 25, Nos. 10-11, pp. 201-277, 1949 .

261. Connell, Robert C., Neffect of Shoulder Parking on Vehicle Operation," Trafic Engineering, Vol. 22, No. 1, pp. 21-26, October 1951.

262. Ogawa, T., E. S. Fisher, and J. C. Oppenlander, "Driver Behavior Study: Influence of Speed Ifmits on Spot-Speed Characteristics in a Series of Cont1guous Rural and Urban Areas," Department of Civil Finglneering, University of Illinols, Urbana, Illinois, September 1961.

263. "Opinions of State Trapfic Safety Officials About Various Aspects of the Speed Situation: Results of a uestionnaire Survey," Association of Casualty and Surety Companies, Accident Prevention Department, New York, 1955, Highway Research Abstracts, Vol, 25, No. 10, pp. 14-15, November 1955.

264. Oppenlander, J. C., "Influence of Out-of-State Passenger Cars on Spot-Speed Characteristics," Department of Civil Engineering, Untversity of Illinois, Urbana, Illinols, May 1962.

265. OShea, Jerry, "Speed Zoning," Proceedings, The Fifth California Street and Highway Conference, p. 61, February 4-6, 1953.

266. Ottini, Ralph, "State Speed Limits and Their Relation to Safety," Proceedings, Western Association of State Highway Officials, p. 326, Apri1 1956.

267. Palmer, M. R., "The Development of Traffic Congestion," Quality and Theory of Traffic Flow, Bureau of Highway Traffic, Yale University, pp. 105-140, 1961 . 
268. Paustian, R. G., 3peed Regulation and Control on Rural Highways, Special Investigation by Highway Research Board, pp. 1-87, 1940.

269. "Pennsylvaniz Turnpike Speed Isimits SIashed in New Safety Move," Transport Topics, No. 969, pp. 1, 13, Janury 12, 1953.

270. Perkins, Ernest T., "Highways with a Narrow Median -- Connecticut," Highway Research Board, Bulletin No. 35, pp. 19-44, 1951.

271. Petty, Ben H., "A Study of Highway Traffic Speeds," Better Roads, Vol. 6, No. 3, pp. 21-23, March 1936.

272. Petty, Ben H., "Speed Kills," Better Roads, Vol. 6, No. 10, pp. 1518, Cotober 1936.

273. "Planning an Effective Speed Control Program," Traffic Safety, Vol. 52, No. 4, p. 34, April 1958.

274. Porter, Harry, Jr., "Speeds and Speed Limits," Traffic Review, Vol. 5, No. 2, pp. 8-10, 39-40, 1951.

275. Powers, L. D. and H. L. Michael, "Effects on Speed and Accidents of Improved Delineation at Three Hazardous Locations," Highway Research Board, Bulletin 303, pp. 10-24, 1961.

276. Powers, I. D. and H. I. Michael, "The Effects on Speed and Accidents of Improved Delineation of Three Hazardous Locations," Joint Highway Research Project, Purdue UnIversitj, No. 3, January 1961.

277. Powers, Thomas M., "Radar Speed Checking in Akron," Traffic Review, Vol. 6, No. 2, pp. 9-13, 1952.

278. Price, Harry 0., "The Effect on Vehicle Speeds of a Speed Zone Anead Sign and of Speed Numerals Painted on the Pavement, "The Institute of Transportation and Traffic Engineering, University of California, Student Research No. 1, 1951.

279. Prisk, C. W., "Passing Practices on Rural Highways," Proceedings, H1ghway Research Board, Vol. 21, pp. 366-378, 1941.

280. Prisk, C. W., "The Elfect of Barrier-Line Location at No-Passing Zones," Public Roads, Vol. 27, No. 2, p. 24, June 1952.

281. "Progressive Speed Study 1954," Missouri State Highway Department, Division of Highway Planning, with the Bureau of Public Roads, pp. 1-3, 1954 .

282. "Public Polled Problems of Traffic Safety," Better Roads, Vol. 16, No. 4, pp. 29-30, 1946. 
283. "Public Response to Speed Zoning," Ilinois Highway Bulletin, Division of Highways, Springfield, Ilinois, Vol. 24, Nos. 9, 10, September and October 1958.

284. Quimby, Varren S., "Present Trends in Traffic Speeds, "Purdue University Engineering Experiment Station, Reprint No. 37, July 1948.

285. Quimby, Varren S., "Triffic Patterns at a Narrow Bridge," Proceedings, Highway Research Board, Vol. 27, pp. 283-284, 1947.

286. "Radar Meter Catches Only Speed V1olators," Science News Letter, Vol. 7C, No. 24, p. 377, December 15, 1956.

287. Raff, Morton S., "Speeds on Rural Highways, Past and Present," Proceedings, H1ghway Research Board, Vol. 30, p. 329-335, 1950.

288. Reeder, E. J., "Critical Speeds at the Danger Points," Public Safety, Vol. 5, №. 7, pp. 15-17, July 1931.

289. Reeder, E. J., "Critical Speeds on H1ghway Curves," Public Safety, Vol. 8-10, pf. O-11, December 1934.

290. Reeder, E. J., "How SIOw is SIow?" American City, Vol. 46, No. 5, pp. 111-113, May 1936.

291. Reeder, E. J., That "ill Be Next in Speed Regulation?" Public Safety, Vol. 5, No. 9, pp. 21-23, September 1931.

292. "Report on the 30 MPH Speed Limit in London Traffic Area," Ministry of Transport and Civil Aviation, London, 1956, Road Abstracts (Department of Scientilic and Industrial Research, Road Research Laboratory), London, Vol. 23, No. 7, pp. 160-161, 1956.

293. Report of the Lima Traffic Survey, The City of Lima, Division of Public Service Department of Engineering and Construction, pp. 80$86,1937$.

294. "Report of Speeds at High Speed Locations on IIlinois Rural State Highways," State of Ilino1s, Department of' Public Works and Buildings, Division of Highways, Bureau of Traffic, February 1956.

295. "Researchers Apply Their Efforts to War Problems," Better Rodds, Vol. 13, No. 1, p. 20, January 1943.

296. Ribicoff, Abe., "How We Cut Our Auto Death Rate," Saturday Evening Post, Vol. 229, No. 10, pp. 31, 128-130, September 8, 1956.

297. Ricker, Edmund R., "Monitoring Traffic Speed and Volume," Traffic Quarterly, Vol. 13, No. 1, pp. 128-140, January 1954.

298. Ritter, L. J., Jr. and R. J. Paquette, Highway Fngineering, The Ronald Press Company, New York, pp. 125-148, 1951. 
299. Roid Jser Benefit inalysis for Highway Improvements, Washington, D. C., imerican Association of State Highway Officials, pp. 53-54, $69-89$, January 1960.

300. Rothrock, C. A. and Harold Eckhirdt, "Influence of Shculders on Traffic Operations," Highway Research Abstracts, Vol. 20, No. 5, pp. 15-31, May 1950.

301. Rowan, f.rthur H., "Ontario's Traffic-Fatality Figures and the Lessons They Teach," Roads and Engineering Construction, Vol. 92, ivo. 3, pp. 129-136, Mirch 1954 .

302. Rowan, Neilson J. and Charles J. Keese, "A Study of Factors Influencing Trafic Speeds," Texas Transportation Institute, $\dot{r}$ and $M$ College of Texas, College St stion, Texas, (preliminary draft), Sept amber 1961.

303. Russoll, Frederick C., "Cutting Car Speed Presents Grive Problems to Motorists," Mryl Ud Motorist, Wl. 22, No. 8, p. 5, August 1942.

304. Rgres, R. A., Road Safety, the Sanitary Publishing Company, Ltd., The lechnical Publishing Company, Ltd., London, undated, p. 20; Road Abstract, Great Britiin Scientific and Industrial Research Depirtment, Vol. 14, No. 1C, p. 127.

305. Saal, C. C., "Hill-Climbing Ability of Motor Trucks," Proceedings, Highway Research Board, Vol. 21, pp. 393-406, 19141.

306. Sacil, C. C., "Hill-Climbing Ability of Motor Trucks," Public Roads, voi. 23, No. 3, pp. 33-54, My 14.

307. Saal, C. C., "Operating Characteristics of a Passenger Car on Selected Routes," Highway Reseárch Board, Bulletin 107, pp. 1-28, 1955.

308. Scheid, C. S., "rew Speed Regulations in Oklahoma City," Traffic Digest and Review, Vol. I, lo. 5, p. 7, August 1953.

309. Scheidt, Edwerd, "Enforcing Liw on Slow Driving," Praffic Quarterly, vol. 8, No. 3, pp. 269-28C, July 1954.

310. Schnal, Robert, Measuring Car Speeds," Public SafetI, Vol. 41 , №. 4, pp. 8-9, April 1952.

311. Schmidt, Robert E., "Highway Speeds vs Horsepower," Traffic QuarterIy, Vol. 8, No. 3, pp. 339-350, July 1954.

312. Schwender, H. C., O. K. Normann, and J. O. Cranum, "New Methods of Capacity Determination tor Rural Rocids in Mountainous Terrain," Highway Research Board, Bulletin 167, pp. 10-37, 1957. 
313. Jurivner, Frank H., "Hotion of Heavy Vehiules on Highways, "Texas Highways, Vol. ?, No. 1, pp. 166-172, 1054.

314. Scrivner, Frank H., "Triflic Operation at Expressway Entrances," Texis Highweys, 25 th Annuil Highway Short Course, Special Issue,

315. Seburn, T. J., "Capitalizing on Safety Campaigns," Proceedings, Institute of Traffic Encineers, pp. 43-48, 1940.

316. Seburn, ". J., "Lower Soeed Limits at Night," The American City, pp. 163-165, June 2939; Highway Research Abstract, No. 62, p. 9, July 1939.

317. Seburr, T. J., "Reduced Speed for Safe Night Driving," Proceedings, Institute of Traffic Engineers, Vol. 10, pp. 61-63, October 1939.

318. Shrp, $\because$. H., "Specd Zone Studies in Connecticut," Iraffic Engineering, Vol. 16, №. 11, pp. 430-434, hugust 1:466.

319. Shelby, $K . D$. and P.R. Tuff, "Vericle Speed and Placement Survey," Highway Research Bo'trd, Bulletin 170, pp. 24,-50, 1958.

320. Shumite, Robert F., "Effect of Enforcement on Driving Speeds," Project No. 533, In Cooperation with the Traffic Institute of Northwestern University and the U. S. Bureau of Public Roads.

321. Shumite, Robert P., "Effect of' Increased Patrol on Accidents, Diversion, and Spced," The 'Traffic Institute, Northwestern University, Plescarch Project ili3, 1:59.

322. Shumate, R. P. and R. F. Crowther, Nariabillty of Fixed-Point Speed Measurements," lighway hesearch Board, Bulletin 281, pp. 87-96, 1961.

323. Sielski, M. C., "What Should the Maximum Speed Limit Be?" Traffic Engineering, Vol. 26, No. 12, p. 548, 1956.

324. Simpson, R. E., "Whentieth Century Speed Plus Nineteenth Century Visibility," Safety Englneering, Vol. 68, No. 5, pp. 193-196, 1934.

325. Smeed, R. J., "Road User Behavior in Relation to Road Conditions," Traffic Engineering, Vol. 25, No. 2, p. 361, June 1955.

326. Sineed, R. J., "Some Factors Influencing the Road Behavior of Vehicle Drivers," Operational Research iuarterly, Vol. 3, No. 4, pp. 60-67, December 1952.

327. Smeed, R. J., "The Influence of Speed and Speed Regulations on Traffic Flow and Accidents," Road Research Lüboratory, Presented at Fifth International Study Week in Traffic Engineering, Nice, 1960. 
329. Jmith, Vilbur S., "Control of Speeds with Signs and Marl ings," Proceedings, Irstitute of Traffic Engineers, Vol. 10, pp. $34-40$,

329. Smith, "ilour S., Methods for Speed Zoning," public Safety, Vol. 14, No. 18, pp. 12-13, 38, October 1938.

330. Smith, Vilbur S. and C. S. LeCraw, Jr., "Speed Laws and Enforcement," Iraffic euarterly, Vol. 1, No. 2, pp. 117-133, Apri1 1947.

331. Saith, Wilbur S. and C. S. LeCraw, Ir., Mraific Speed Enforcement Pollcies," Eno Foundation for Highway Traffic Control, Saugatuck, Connecticut, 90 pages, 1948.

332. Smith, Wilbur S. and C. S. LeCraw, Jr., "Iravel Speeds and Posted Speeds in Three States, "Traffic Quarterly, Vol. 2, No. 1, p. 101, January 1949.

333. "Wome Chracteristics of Highway Traftic In Rhode IsInd, "Public Rosds, Vol. 16, No. 11, pp. 238-239, January 16, 1936.

334. "Jpeed," Associ tion of Casu lty and Surety Companies, New York, No. 2, 7 pages, February 1957.

335. "Speed and Highway Safety," Better Roads, Voi. 7, No." 12, pp. 35, 36,38 , December 1937 .

336. "Speed Characteristics on Vertical Curves," New York State Department of Public Works, albany, N. Y., 195?.

337. "Speed Characteristics Study Made on Rural Highways of New York State," Highway Builder, Vol. 32, No. 5, pp. 11, 17, Nay 1953.

338. "Speed Checked on Turnpike," Better Roads, Vol. 27, No. 3, p. 54, March $195 \%$.

339. "Speed Control," Joint Comittee on Post-War Speed Controls, December 1945.

340. "Speed Habits of Automobile Drivers Observed Repeatedly on a Rural Highway," New York State Department of Public Works, Albany, N. Y., 1954.

341. "Speed Veter Minimizes Tral"ic Accidents," The American City, Vol. 69, No. 2, p. 187, February 1954.

342. "Speed on Rural Highways," Illinois Highway Bulletin, Division of H1ghways, Vol. 22, Nos. 5, 6, May and June 1956.

343. Speed Regulation, A Report of the Comittee on Speed, Traffic and Transportation Conference, National Saf'ety Council, Chicago, January 1958. 
344. "Speed Report," Mraffic Division, Michigan State Highway Department, April 1962.

345. "Speed Restriction," Michigan Roads and Construction, p. 6, March 4, 1937; Highway Research Abstract, №. 39, p. 7, 1937.

346. "Speed Studies," Saf'ety Bureau, Missouri State Highway Department, Special Report, H4ghway Research Abstracts, No. 80, pp. 2-3, May 1941 .

347. "Speed ... The Greatest Contributing Cause to Traffic Accident Severity in Indiana," Indiana State Police, Indianapolis, August 15,1950 .

348. "Speed Trends on Main Rural Highways by Vehicle Type," Highway Statistics, U. S. Department of Commerce, Bureau of Public Roads, 1960.

349. "Speed Zones and Safety," Better Roads, Vol. 8, No. 11, pp. 20, 2526. November 1938.

350. Speed Zoning, American Automobile Association, Washington, D. C., June 3, 1952 .

351. "Speeding Drivers Cancel Safety Work of Highway Engineers," Traffic Engineering, Vol. 23, No. 3, pp. 99, 101, December 1952.

352. "Speeds of Passenger Cars on Wet and Dry Pavements," New York State Department of Public Works, Bureau of Highway Planning, 1955, unpublished.

353. "Speeds on Saskatchewan Highways - 1959," Planning Branch, Department of Highways and Transportation, Saskatchewan.

354. Stack, Herbert J., "To the Editor," Popular Mechanics, Vol. 101, pp. 10, 14, February 1954 .

355. Stack, Herbert J. and others, "A Survey of the Uses of Radar in Speed Control Activities," Traffic Quarterly, Vol. 8, No. 4, p. 433, 1954 .

356. Stadle, A., "No Accident Psychosis -- The Pros and Cons of Speed Limits," Dstch Strassenverkehr, Vol. 4, No. 4, pp. 97-99, 1954; Road Abstracts (Department of Scientific and Industrial Research, Road Research Laboratory), London, Vol. 23, No. 5, pp. 112-113, 1956.

357. Staffeld, Paul R., "Accidents Related to Access Points and Advertising Signs in Study," Traffic Quarterly, Vol. 7, No. 1, pp. 63-65, January 1953. 
358. Stalder, Harold I. and A. R. Lauer, "Effect of Pattern Distribution on Preception of Relative Motion in Low Levels of Illumination," Highway Research Board, Bulletin 56, pp. 25-35, January 1952.

359. "Statewide Commerc18l-Vehicle Speed Study," Highway Research Austracts, Vol. 23, No. 4, pp. 3-4, April 1953.

360. "Step Off the Gas," Collier's, Vol. 95, No. 14, p. 62, April 6, 1935.

361. Stevens, J. W., "Truck Speed and Time Loss on Grades," Transactions, American Society of Civil Engineers, Vol. 112, pp. 1023-1042, 1947.

362. Stewart, Roger G., "Are We Over-Emphasizing Speed as an Accident Cause?" Traffic Quarterly, Vol. XI, No. 4, pp. 573-579, October 1957.

363. Stewart, Roger G., "Reported Driving Speeds and Previous Accidents," Institute of Transportation and Traffic Englneering, University of California, Reprint No. 59, 1958.

364. Stoeckel, Robbins B., "Speed as Car Advert1sing Slogan Will Bring New Flood of Restri tive Road Laws," Automot1ve Industries, Vol. 67, No. 4, pp. 106-109, July 1932.

365. Stohner, Walter R., "Speeds of Passenger Cars on Wet and Dry Pavements," Highway Research Board, Bulletin 139, pp. 79-84, 1956.

366. Stonex, K. A., "Effect of Governors on Passenger Car Performance," Proceedings, Highway Research Board, Vol. 35, pp. 577-584, 1956.

367. Stonex, K. A., "Lessons Learned by the Proving Ground Englneer in Highway Design and Traffic Control," Proceedings, Institute of Traffic Engineers, pp. 23-45, October 26, 1955.

368. Stonex, K. A., "Relation Between Automobile and Highway," ProceedIngs, Highway Research Board, Vol. 33, pp. 91-95, 1955.

369. Stonex, K. A. and C. M. Noble, "Curve Design and Tests on the Pennsylvania Turnpike," Proceedings, Highway Research Board, Vol. 20, pp. 429-451, 1940 .

370. Strickland, Richard I., "A Study of Merging Vehicular Traffic Movement," Technical Report No. 4, Yale Bureau of Highway Traffic, pp. 81-100, May 1947.

371. Swain, Robert 0., "Speed Transition Ramps on a Bridged Rotary," Public Roads, Vol. 24, No. 12, pp. 307-311, April-May-June 1947.

372. Swain, Robert 0., "Speed Zoning in Texas," Traffic Engineering, Vol. 12, No. 15, pp. 407-408, July 1942. 
328. Smith, Wilbur S., "Control of Speeds with Signs and Meirlines," Proceedings, Institute of Traffic Engineers, Vol. 10, pp. $34-4 \mathrm{C}$,

329. Smith, wilbur S., Methods for Speed Zoning," Public Sarety, Vol. 14, No. 18, pp. 12-13, 38, October 1938.

330. Smith, Wilbur S. and C. S. LeCraw, Jr., "Speed Laws and Eniorcement," Trafilc zuarterly, Vol. 1, No. 2, pp. 117-133, April 1947.

331. Smith, Wilbur S. and C. S. LeCraw, Jr., "Traflic Speed Enforcement Pol1cies," Eno Foundation for Highway Traffic Control, Saugatuck, Connecticut, 90 pages, 1948.

332. Smith, Wilbur S. and C. S. LeCraw, Jr., "iravel Speeds and Posted Speeds in Three States," "1rafic Quarterly, Vol. 2, No. 1, p. 101, January 1949.

333. "Wome Characteristics of Highway Traffic In Rhode Island," Public Roads, Vol. 16, No. 11, pp. 238-239, January 16, 1936.

334. "Speed," Associztion of Casu1lty and Surety Companies, New York, No. 2, 7 piges, February 1957.

335. "Soeed and Highway Safety," Better Roads, Vol. 7, No. 12, pp. 35, 36,38 , December 1.937.

336. "Speed Characteristies on Vertical Curves," New York State Departmert of Public Works, Albany, N. Y., 1953.

337. "Speed Characteristics Study Made on Rural Highways of New York State," Highway Builder, Vol. 32, No. 5, pp. 11, 17, May 1953.

338. "Speed Checked on Turnpike," Better Roads, Vol. 27, No. 3, p. 54, March $195 \%$.

339. "Speed Control," Joint Comittee on Post-ivar Speed Controls, December 1945.

340. "Speed Habits of Automob1le Drivers Observed Repeatedly on a Rural Highway," New York State Department of Public Works, Albany, N. Y., 1954 .

341. "Speed Meter Minimizes Trallic Accidents," the American City, Vol. 69, No. 2, p. 187, February 1954.

342. "Speed on Rural Highways," Illinois Highway Bulletin, Division of" Highways, Vol. 22, Nos. 5, 6, May and June 1956.

343. Speed Regulation, A Report of the Comittee on Speed, Iraffic and iransportation Conference, National Safety Council, Chicago, January 1958. 
344. "Speed Report," Traffic Division, Michigan State Highway Department, April 1962.

345. "Speed Restriction," Michigan Roads and Construction, p. 6, March 4. 1937; Highway Research Abstract, No. 39, p. 7, 1937.

346. "Speed Studies," Sal'ety Bureau, Missouri State Highway Department, Special Report, Hghway Research Abstracts, No. 80, pp. 2-3, May 1941.

347. "Speed ... The Greatest Contributing Cause to Traffic Accident Severity in Indiana," Indiana State Police, Indianapolis, August $15,1950$.

348. "Speed Trends on Main Rural Highways by Vehicle Type," Highway Statistics, U. S. Department of Commerce, Bureau of Public Roads, 1960.

349. "Speed Zones and Safety," Better Roads, Vol. 8, No. 11, pp. 20, 2526. November 1938.

350. Speed Zoning, American Automobile Association, Washington, D. C., June 3, 1952.

351. "Speeding Drivers Cancel Safety Work of Highway Englneers," Traffic Engineering, Vol. 23, No. 3, pp. 99, 101, December 1952.

352. "Speeds of Passenger Cars on Wet and Dry Pavements," New York State Department of Public Works, Bureau of Highway Planning, 1955, unpublished.

353. "Speeds on Saskatchewan Highways - 1959," Planning Branch, Department of Highways and Transportation, Saskatchewan.

354. Stack, Herbert J., "To the Editor," Popular Mechanics, Vol. 101, pp. 10, 14, February 1954 .

355. Stack, Herbert J. and others, "A Survey of the Uses of Radar in Speed Control Activities," Traffic Quarterly, Vol. 8, No. 4, p. 433, 1954 .

356. Stadle, A., 'No Accident Psychosis -- The Pros and Cons of Speed Limits," Dstch Strassenverkehr, Vol. 4, No. 4, pp. 97-99, 1954; Road Abstracts (Department of Scientific and Industrial Research, Road Research Laboratory), London, Vol. 23, No. 5, pp. 112-113, 1956.

357. Staffeld, Paul R., "Accidents Related to Access Points and Advertising Signs in Study," Traffic Quarterly, Vol. 7, No. 1, pp. 63-65, January 1953. 
358. Stalder, Harold I. and A. R. Lauer, "Effect of Pattern Distribution on Preception of Relative Motion in Low Levels of Illumination," Highway Research Board, Bulletin 56, pp. 25-35, January 1952.

359. "Statewide Comercial-Vehicle Speed Study," Highway Research Abstracts, Vol. 23, No. 4, pp. 3-4, April 1953.

360. "Step Off the Gas," Collier's, Vol. 95, No. 14, p. 62, April 6, 1935.

361. Stevens, J. h., "Truck Speed and Time Loss on Grades," Transactions, American Society of Civil Engineers, Vol. 112, pp. 1023-1042, 1947.

362. Stewart, Roger G., "Are We Over-Emphasizing Speed as an Accident Cause?" TrafPic Quarterly, Vol. XI, No. 4, pp. 573-579, October 1957.

363. Stewart, Roger G., "Reported Driving Speeds and Previous Accidents," Inst1tute of Transportation and Traffic Engineering, University of California, Reprint No. 59, 1958.

364. Stoeckel, Robb1ns B., "Speed as Car Advertising Slogan will Bring New Flood of Restrictive Road Laws," Automotive Industries, Vol. 67, No. 4, pp. 106-109, July 1932.

365. Stohner, Walter R., "Speeds of Passenger Cars on Wet and Dry Pavements," Highway Research Board, Bulletin 139, pp. 79-84, 1956.

366. Stonex, K. A., "Effect of Governors on Passenger Car Performance," Proceedings, Highway Research Board, Vol. 35, pp. 577-584, 1956.

367. Stonex, K. A., "Lessons Learned by the Proving Ground Engineer in Highway Design and Traffic Control," Proceedings, Institute of Traff1c Englneers, pp. 23-45, October 26, 1955.

368. Stonex, K. A., "Relation Between Automobile and Highway," ProceedIngs, Highway Research Board, Vol. 33, pp. 91-95, 1955.

369. Stonex, K. A. and C. M. Noble, "Curve Design and Tests on the Pennsyltania Turnpike," Proceedings, Highway Research Board, Vol. 20, pp. 429-451, 1940 .

370. Strickland, Richard I., "A Study of Merging VehIcular Traffic Movement," Technical Report No. 4, Yale Bureau of Highway Traffic, pp. $81-100$, May 1947.

371. Swa1n, Robert 0., "Speed Transition Ramps on a Bridged Rotary," Public Roads, VoI. 24, No. 12, pp. 307-311, April-May-June 1947.

372. Swain, Robert 0., "Speed Zoning in Texas," Traffic Eng1neering, Vol. 12, No. 15, pp. 407-408, July 1942. 
328. Smith, "ilbur S., "Control of Jyeeds with Signs and Markings," Proceedings, Institute of Traffic Engineers, Vol. 10, pp. 34-40,

329. Smith, Viliour S., "ridethods for Speed Zoning," Public Sarety, Vol. 14, No. 18, pp. 12-13, 38, October 1038.

330. Smith, fillbur S. and C. S. LeCraw, Jr., "Speed Laws and Enforcement," Traifiz iurterly, Vol. 1, No. 2, pp. II7-133, ipril 19:47.

331. Smith, Hilbur S. and C. 3. LeCraw, Jr., "Traffic ipeed Enforcement Pollcies," Eno Foundation for Highway Praffic Control, Saugatuck, Connecticut, 90 pages, 1948.

332. Smith, Wilbur S. and C. S. LeCraw, Jr., "Iravel Speeds and Posted Speeds in Three States," "hrafic Quarterly, Vol. 2, No. 1, p. 101, January 1949.

333. "Some Chracteristics of Highway Tretfic in Rhode Isl nd," Public Roads, Vol. 16, No. 11, pp. 238-239, January 16, 1936.

334. "Speed," Associztion of Casu lty and Surety Companies, New York, No. 2, 7 pages, February 1957.

335. "Speed and Highway Safety," Better Roads, Vol. 7, No. 12, pp. 35, 36,38 , December 1937.

336. "Speed Characteristics on Vertical Curves," New York State Department of Public Works, ilbany, N. Y., I953.

337. "Speed Characteristics Study Made on Rural Highways of New York Stite," Highway Builder, Vol. 32, No. 5, pp. 11, 17, May 1953.

338. "Speed Checked on Turnpike," Better Roads, Vol. 27, No. 3, p. 54, March $195 \%$.

339. "Speed Control," Joint Comittee on Post-liar Speed Controls, December 1945.

340. "Speed Habits of Automobile Drivers Observed Repeatediy on a Rural Highway," New York State Department of Public Works, Albany, N. Y., 1954.

341. "Speed Heter Minimizes Tralfic Accidents," the American City, Vol. 69, No. 2, p. 187, February 1954.

342. "Speed on Rural Highways," Illinois Highway Bulletin, Division of" Highways, Vol. 22 , Nos. $5, \overline{6, k y}$ and June 1956.

343. Speed Regulation, A Report of the Committee on Speed, Traffic and 'hansportation Conference, National Sat'ety Council, Chicago, January 1958 . 
344. "Speed Report," Traffic Division, Michigan State Highway Department, April 1962.

345. "Speed Restriction," Michigan Roads and Construction, p. 6, March 4, 1937; Highway Research Abstract, No. 39, p. 7, 1937.

346. "Speed Studies," Saf"ety Bureau, Missouri State Highway Department, Special Report, Hy ghway Research Abstracts, No. 80, pp. 2-3, May 1941.

347. "Speed ... The Greatest Contributing Cause to Traffic Accident Severity in Indiana," Indiana State Police, Indianapolis, August $15,1950$.

348. "Speed Trends on Main Rural Highways by Vehicle Type," Highway Statistics, U. S. Department of Commerce, Bureau of Public Roads, 1960.

349. "Speed Zones and Safety," Better Roads, Vol. 8, No. 11, pp. 20, 2526. November 1938.

350. Speed Zoning, American Automobile Association, Washington, D. C., June 3, 1952 .

351. "Speeding Drivers Cancel Safety Work of Highway Engtneers," Traffic Engineering, Vol. 23, No. 3, pp. 99, 101, December 1952.

352. "Speeds of Passenger Cars on Wet and Dry Pavements," New York State Department of Public Works, Bureau of Highway Planning, 1955, unpublished.

353. "Speeds on Saskatchewan Highways - 1959," Planning Branch, Department of Highways and Transportation, Saskatchewan.

354. Stack, Herbert J., "To the Editor," Popular Mechanics, Vol. 101, pp. 10, 14, February 1954.

355. Stack, Herbert J. and others, "A Survey of the Uses of Radar in Speed Control Activities," Traffic Quarterly, Vol. 8, No. 4, p. 433, 1954.

356. Stadle, A., "No Accident Psychosis -- The Pros and Cons of Speed Limtts," D'stch Strassenverkehr, Vol. 4, No. 4, pp. 97-99, 1954; Road Abstracts (Department of Scientific and Industrial Research, Road Research Laboratory), London, Vol. 23, No. 5, pp. 112-113, 1956.

357. Staffeld, Paul R., Mccidents Related to Access Points and Advertising Signs in Study," Traffic Quarterly, Vol. 7, No. 1, pp. 63-65, January 1953. 
358. Stalder, Harold $I$. and A. R. Lauer, "Effect of Pattern Distribution on Preception of Relative Motion in Low Levels of Ilumination," Highway Research Board, Bulletin 56, pp. 25-35, January 1952.

359. "Statewide Commercial-Vehicle Speed Study," Highway Research Atstracts, Vol. 23, ITo. 4, pp. 3-4, April 1953.

360. "Step off the Gas," Collier's, Vol. 95, No. 14, p. 62, April 6, 1935.

361. Stevens, J. W., "Truck Speed and Time Loss on Grades," Transactions, American Society of Civil Engineers, Vol. 112, pp. 1023-1042, 1947.

362. Stewart, Roger G., "Are We Over-Fmphasizing Speed as an Accident Cause?" Iraffic Quarterly, Vol. XI, No. 4, pp. 573-579, October 1957.

363. Stewart, Roger G., "Reported Driving Speeds and Prevlous Accidents," Institute of Transportation and Traffic Engineering, University of California, Reprint No. 59, 1958.

364. Stoeckel, Robbins B., "Speed as Car Advertising Slogan Will Bring New Flood of Restrictive Road Laws," Automctive Industrles, Vol. 67, No. 4, pp. 106-109, July 1932.

365. Stohner, Walter R., "Speeds of Passenger Cars on Wet and Dry Pavements," H1ghway Research Board, Bulletin 139, pp. 79-84, 1956.

366. Stonex, K. A., "Effect of Governors on Passenger Car Performance," Proceedings, Highway Research Board, Vol. 35, pp. 577-584, 1956.

367. Stonex, K. A., "Lessons Learned by the Proving Ground Ingineer in Highway Design and Traffic Control," Proceedings, Inst1tute of Traffic Englneers, pp. 23-45, October 26, 1955.

368. Stonex, K. A., "Relation Between Automobile and Hy ghway," Proceedings, Highway Research Board, Vol. 33, pp. 91-95, 1955.

369. Stonex, K. A. and C. M. Noble, "Curve Design and Tests on the Pennsylvania Turnpike," Proceedings, Highway Research Board, Vol. 20, pp. 429-451, 1940.

370. Strickland, Richard I., "A Study of Merging Vehlcular Traffic Movement," Technical Report' No. 4, Yale Bureau of Highway Traffic, pp. 81-100, May 1947.

371. Swain, Robert 0., "Speed Transition Ramps on a Bridged Rotary," Public Roads, Vol. 24, No. 12, pp. 307-311, Apr11-May-June 1947.

372. Swain, Robert 0., "Speed Zoning in Texas," Traffic Engineering, Vol. 12, No. 15, pp. 407-408, July 1942。 
328. Smith, Milbur S., "Control of Speeds With Signs and Marlings,"

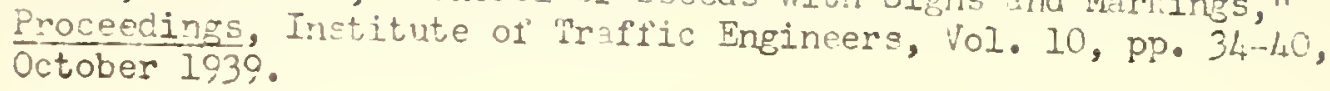

329. Smith, "Nilour S., Methocis for Speed Zoning," Public Sarety, Vol. 14, No. 18, pp. 12-13, 38, October 1938 .

330. Smith, Vilibur S. and C. S. LeCraw, Jr. "Speed Laws and Entorcement," Tralicic zuaterly, Vol. I, No. 2, pp. II7-133, April 1947.

331. Snith, vilbur S. and C. S. LeCraw, Ir., "Traffic Speed Enforcement Policies," Eno Foundation for Highway Traffic Control, Saugatuck, Connecticut, 90 pages, 1948.

33.. Smith, hilbur S. and C. S. LeCran, Jr., "l'ravel speeds and Posted Speeds in Three States," "1rOffic Quarterly, Vol. 2, No. 1, p. 101, Jenuary 1949.

333. "Some Chracteristics of Highway Tratfic in Rhode Islind," PubIic Roads, Vol. 16, No. 11, pp. 238-239, January 16, 1936.

334. "Speed," Association of Casu l.ty and Surety Companies, New York, No. 2, 7 pages, February 1957.

335. "Speed and Highwiy Safety," Better Roads, Vol. 7, No. 12, pp. 35, 36,38 , December 1.937 .

336. "Speed Characteristi s on Vertical Curves," New York State Department of Public Works, Mbany, N. Y., 195:

337. "Speed Chrracteristics Study Made on Rural Highways of New York Stute," Highway Builder, Vol. 32, No. 5, pp. 11, 17, May 1953.

338. "Speed Checked on Turnpike," Better Roads, Vol. 27, No. 3, p. 54, March $195 \%$.

339. "Speed Control," Joint Comittee on Post-Far Speed Controls, December 1945.

34C. "Speed Habits of Automobile Drivers Observed Repeatedly on a Rural Highway," New York State Department of Public Works, Albany, N. Y., 1954.

341. "Speed Heter Minimizes Tratiic Accidents," the American City, Vol. 69, No. 2, p. 187, February 1954.

342. "Speed on Rural Highways," Illinois Highway Bulletin, Division of Highways, Vol. 22, Nos. 5, $\overline{6}$, Mey and June 1956.

343. Speed Regul tion, A Report of the Committee on Speed, Traffic and iransportation Conference, National Saf'ety Council, Chicago, January 1958. 
344. "Speed Report," "Praffic Division, Michigan State Highway Department, April 1962.

345. "Speed Restriction," Michigan Roads and Construction, p. 6, March 4, 1937: Highway Research Abstract, №. 39, p. 7, 1937.

346. "Speed Studies," Safety Bureau, Missouri State Highway Department, Special Report, Highway Research Abstracts, No. 80, pp. 2-3, May 1941.

347. "Speed ... The Greatest Contributing Cause to Traffic Accident Severity in Indiana," Indiana State Police, Indianapolis, August 15,1950 .

348. "Speed Trends on Main Rural Highways by Vehicle Type," Highway Statistics, U. S. Department of Comerce, Bureau of Public Roads, 1960.

349. "Speed Zones and Safety," Better Roads, Vol. 8, No. 11, pp. 20, 2526. November 1938.

350. Speed Zoning, American Automobile Association, Washington, D. C., June 3, 1952.

351. "Speeding Drivers Cancel Safety Work of Highway Englneers," Traffic Engineering, Vol. 23, No. 3, pp. 99, 101, December 1952.

352. "Speeds of Passenger Cars on Wet and Dry Pavements," New York State Department of Public Works, Bureau of Highway Planning, 1955, unpublished.

353. "Speeds on Saskatchewan Highways - 1959," Planning Branch, Department of Highways and Transportation, Saskatchewan.

354. Stack, Herbert J., "To the Editor," Popular Mechanics, Vol. 101, pp. 10, 14, February 1954.

355. Stack, Herbert J. and others, "A Survey of the Uses of Radar in Speed Control Activities," Traffic Quarterly, Vol. 8, No. 4, p. 433, 1954 .

356. Stadle, A., "No Accident Psychosis - The Pros and Cons of Speed Limfts," Dstch Strassenverkehr, Vol. 4, No. 4, pp. 97-99, 1954; Road Abstracts (Department of Scientific and Industrial Research, Road Research Laboratory), Iondon, Vol. 23, No. 5, pp. 112-113, 1956.

357. Staffeld, Paul R., "Accidents Related to Access Points and Advertising Signs in Study," Iraffic Quarterly, Vol. 7, No. 1, pp. 63-65, January 1953. 
358. Stalder, Harold I. and A. R. Lauer, "Effect of Pattern Distribution on Preception of Relative Motion in Low Levels of Illumination," Highway Research Board, Bulletin 56, pp. 25-35, January 1952.

359. "Statewide Commercial-Vehicle Speed Study," Highway Research Abstracts, Vol. 23, No. 4, pp. 3-4, April 1953.

360. "Step Off the Gas," Collier's, Vol. 95, No. 14, p. 62, April 6, 1935.

361. Stevens, J. W., "Truck Speed and Time Loss on Grades," Transactions, American Society of Civil Engineers, Vol. 112, pp. 1023-1042, 1947.

362. Stewart, Roger G., "Are We Over-Emphasizing Speed as an Accident Cause?" Traffic Quarterly, Vol. XI, No. 4, pp. 573-579, October 1957.

363. Stewart, Roger G., "Reported Driving Speeds and Previous Accidents," Institute of Transportation and Traffic Englneering, University of California, Reprint No. 59, 1958.

364. Stoeckel, Robbins B., "Speed as Car Advertising Slogan Will Bring New Flood of Restrictive Road Laws," Automot1ve Industries, Vol. 67, No. 4, pp. 106-109, July 1932.

365. Stohner, Walter R., "Speeds of Passenger Cars on Wet and Dry Pavements," Highway Research Board, Bulletin 139, pp. 79-84, 1956.

366. Stonex, K. A., "Effect of Governors on Passenger Car Performance," Proceedings, Highway Research Board, Vol. 35, pp. 577-584, 1956.

367. Stonex, K. A., "Lessons Learned by the Proving Ground Engineer in Highway Design and Traffic Control," Proceedings, Institute of Traffic Engineers, pp. 23-4.5, October 26, 1955.

368. Stonex, K. A., "Relation Between Automobile and Highway," Proceedings, Highway Research Board, Vol. 33, pp. 91-95, 1955.

369. Stonex, K. A. and C. M. Noble, "Curve Design and Tests on the Pennsylvania Turnpike," Proceedings, Highway Research Board, Vol. 20, pp. 429-451, 1940.

370. Strickland, Richard I., "A Study of Merging Vehicular Traffic Movement," Technical Report No. 4, Yale Bureau of Hghway Traffic, pp. 81-100, May 1947.

371. Swain, Robert 0., "Speed Transition Ramps on a Bridged Rotary," Public Roads, Vol. 24, No. 12, pp. 307-311, Apr1l-May-June 1947.

372. Swain, Robert 0., "Speed Zoning in Texas," Traffic Engineering, Vol. 12, No. 15, pp. 407-408, July 1942. 

